Prepared in cooperation with Oklahoma State University and the Oklahoma Water Resources Board

Determination of Baseline Periods of Record for Selected Streamflow-Gaging Stations in and near Oklahoma for use in Modeling Applications

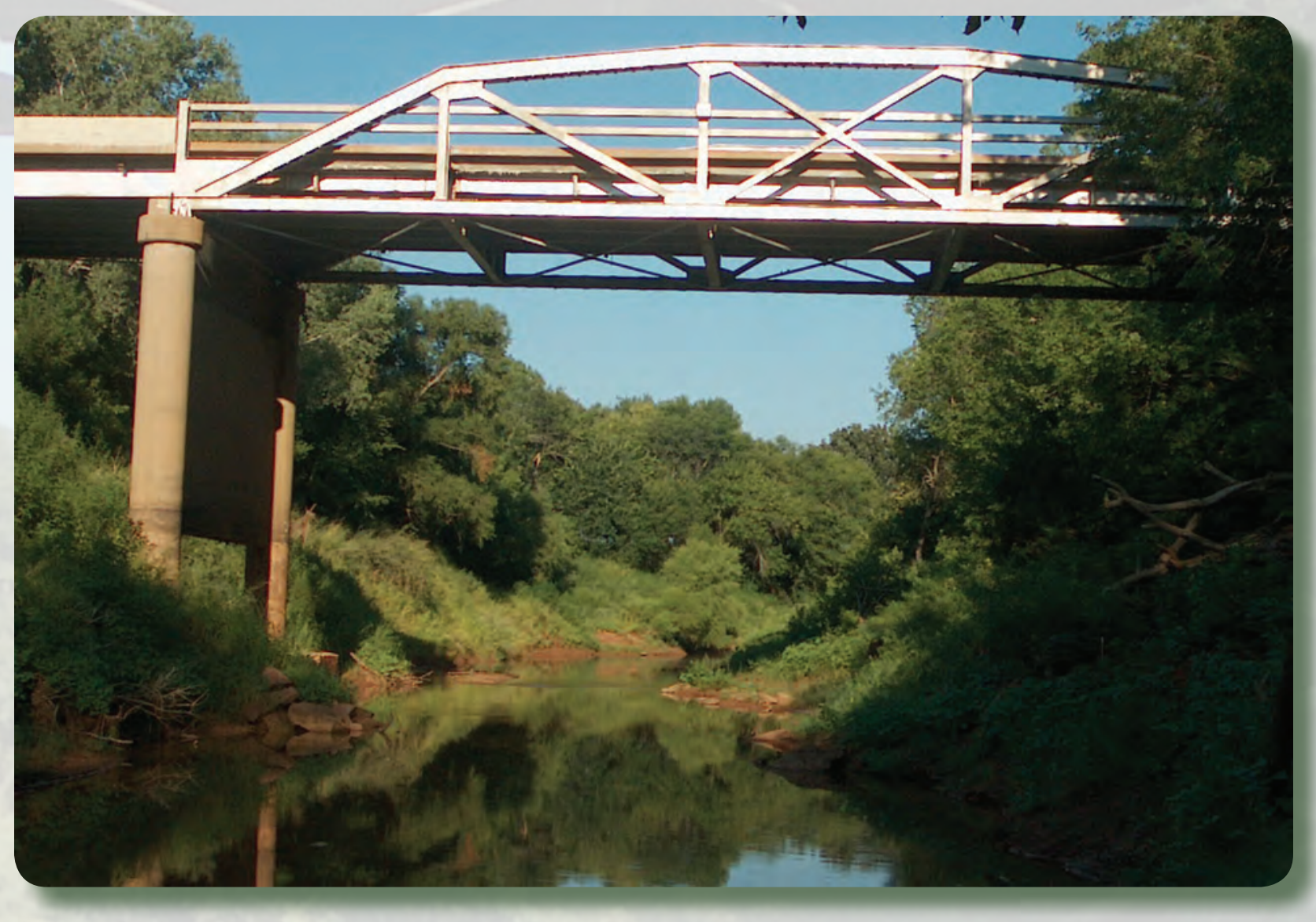

Scientific Investigations Report 2010-5106 
Cover: The bridge and channel at Skeleton Creek near Lovell (07160500), August 2001. Photograph by Martin L. Schneider, U.S. Geological Survey. 


\section{Determination of Baseline Periods of Record for Selected Streamflow-Gaging Stations in and near Oklahoma for use in Modeling Applications}

By Rachel A. Esralew

Prepared in cooperation with Oklahoma State University and the Oklahoma Water Resources Board

Scientific Investigations Repor 2010-5106 


\section{U.S. Department of the Interior \\ KEN SALAZAR, Secretary \\ U.S. Geological Survey \\ Marcia K. McNutt, Director}

U.S. Geological Survey, Reston, Virginia: 2010

This and other USGS information products are available at http://store.usgs.gov/
U.S. Geological Survey
Box 25286, Denver Federal Center
Denver, CO 80225
To learn about the USGS and its information products visit http://www.usgs.gov/
1-888-ASK-USGS

Any use of trade, product, or firm names is for descriptive purposes only and does not imply endorsement by the U.S. Government.

Although this report is in the public domain, permission must be secured from the individual copyright owners to reproduce any copyrighted materials contained within this report.

Suggested citation:

Esralew, R.A., 2010, Determination of baseline periods of record for selected streamflow-gaging stations in and near Oklahoma for use in modeling applications: U.S. Geological Survey Scientific Investigations Report 2010-5106, 65 p. 


\section{Contents}

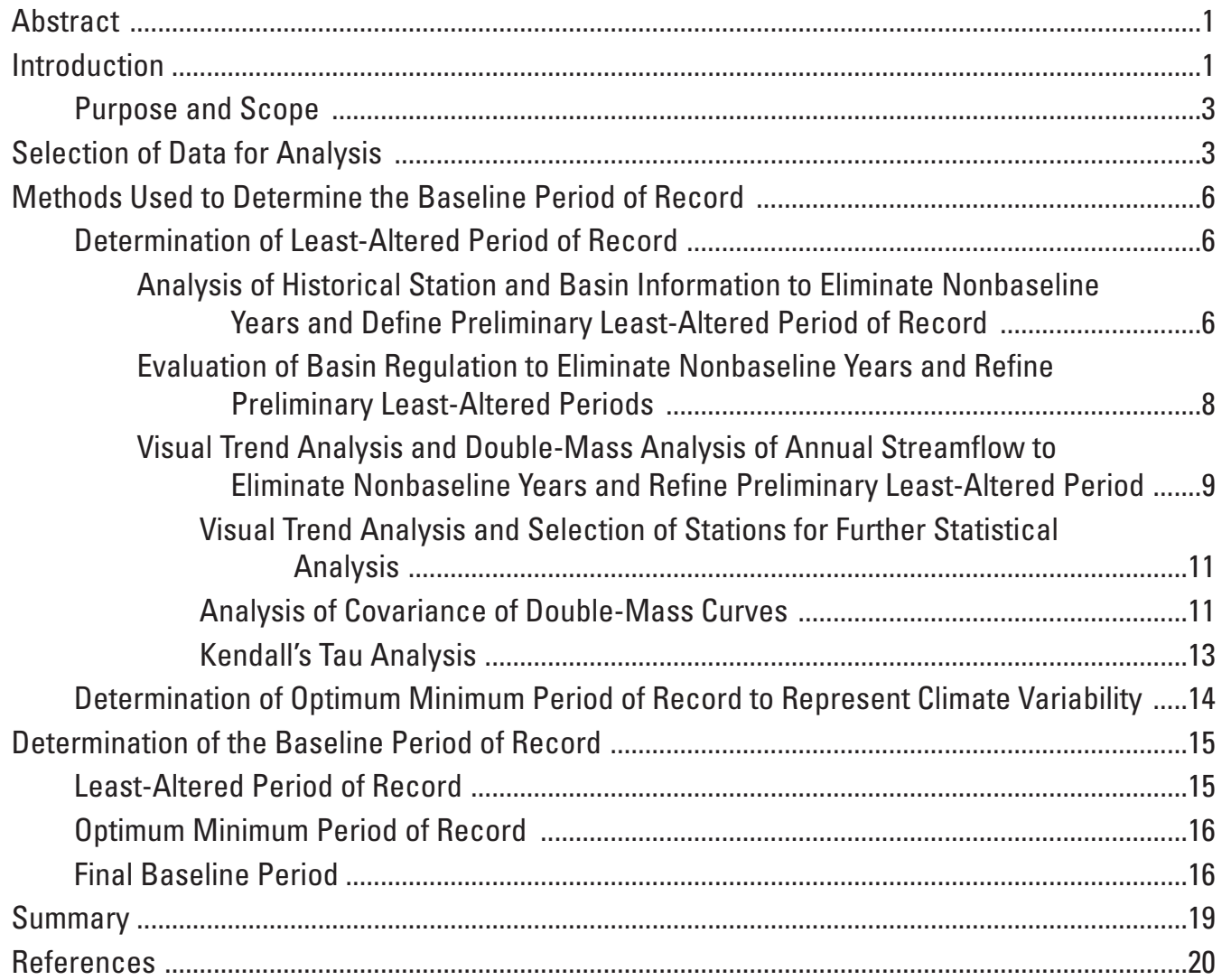

\section{Figures}

1. Map showing selected streamflow-gaging stations with 10 or more years of continuous daily streamflow record and a drainage area of less than 2,500 square miles

2. Chart showing overview of processes used to determine the baseline period of record for selected streamflow-gaging stations

3. Map showing National Weather Service Climate Divisions used in annual precipitation analysis

4. Delineated areas upstream from dams in the basin draining to the U.S. Geological Survey streamflow-gaging station, Washita River near Clinton, Oklahoma, (station ID 07325000) as of (A) 1950, (B) 1956, (C) 1960, and (D) the percentage of the drainage basin upstream from dams with time

5. Example of $(A)$ a time series plot of annual runoff and a Friedman's smooth trendline (Friedman, 1984), and (B) a double-mass curve for cumulative annual precipitation and cumulative annual runoff at Cimarron River near Kenton, Oklahoma, (USGS station identifier 07154500) showing breakpoints that indicate changes in the slope of the relation between precipitation and streamflow. 


\section{6-7. Maps showing:}

6. Climate divisions used in the process to determine a baseline period of record for selected streamflow-gaging stations in and near Oklahoma, and the optimum minimum number of years of streamflow record needed for the baseline period for streamflow-gaging stations in those climate divisions, defined separately for gages located in each climate division for (A) periods of record where more than 50 percent of years occurred prior to 1980, the historically normal period, and (B) periods of record where more than 50 percent of years occurred after 1980s, the historically wet period

7. Selected USGS streamflow-gaging stations with a period of record of 10 or more years, and the final baseline period quality ranking for each station

\section{Tables}

1. Determination of preliminary baseline period for selected stream reaches in and near Oklahoma (in water years) based on streamflow-gaging station history from published U.S. Geological Survey annual data reports (1930-2007), and oral and written communication from staff at the U.S. Geological Survey Oklahoma Water Science Center

2. Preliminary least-altered period of record and quality ranking based on the years that the estimated area upstream from dams in the drainage basins of 115 streamflow-gaging stations in and near Oklahoma equaled or exceeded 1,5, 10, or 20 percent of the drainage-basin area

3. Results and description of visual trends in annual base flow, runoff, total flow, and base-flow index, for the entire period of record for 74 streamflow-gaging stations in and near Oklahoma with at least 20 years of available record

4. Selected results of analysis of covariance test for double-mass curves for annual streamflow data at 11 selected streamflow-gaging stations and annual precipitation data at selected climate divisions in and near Oklahoma.

5. Results of Kendall's tau trend test of selected annual flow parameters for nine selected streamflow-gaging stations in and near Oklahoma

6. Results of the determination of an optimum minimum number of years of streamflow record to consider as a baseline period of record on the basis of testing of variability of annual precipitation between shorter sub-periods and the period 1925-2007 using a Wilcoxon rank-sum test

7. Final baseline period of record for 111 streamflow-gaging stations in and near Oklahoma with at least 10 years of continuous daily streamflow record and a drainage area of less than 2,500 square miles. 


\section{Conversion Factors}

\section{Inch/Pound to SI}

\begin{tabular}{lcl}
\hline & Multiply & \multicolumn{1}{c}{ By obtain } \\
\hline inch (in.) & Length & \\
inch (in.) & 2.54 & centimeter $(\mathrm{cm})$ \\
foot (ft) & 25.4 & millimeter $(\mathrm{mm})$ \\
mile (mi) & 0.3048 & meter $(\mathrm{m})$ \\
\hline & 1.609 & kilometer $(\mathrm{km})$ \\
\hline acre & Area & \\
acre & 4,047 & square meter $\left(\mathrm{m}^{2}\right)$ \\
acre & 0.4047 & hectare $($ ha) \\
acre & 0.4047 & square hectometer $\left(\mathrm{hm}^{2}\right)$ \\
square mile $\left(\mathrm{mi}^{2}\right)$ & 0.004047 & square kilometer $\left(\mathrm{km}^{2}\right)$ \\
square mile $\left(\mathrm{mi}^{2}\right)$ & 259.0 & hectare $($ ha) \\
\hline & 2.590 & square kilometer $\left(\mathrm{km}^{2}\right)$ \\
\hline cubic foot per second $\left(\mathrm{ft}^{3} / \mathrm{s}\right)$ & Flow rate & \\
inch per year $(\mathrm{in} / \mathrm{yr})$ & 0.02832 & cubic meter per second $\left(\mathrm{m}^{3} / \mathrm{s}\right)$ \\
\hline
\end{tabular}

Vertical coordinate information is referenced to the insert datum name (and abbreviation) here for instance, "North American Vertical Datum of 1988 (NAVD 88)."

Horizontal coordinate information is referenced to the insert datum name (and abbreviation) here for instance, "North American Datum of 1983 (NAD 83)."

Altitude, as used in this report, refers to distance above the vertical datum.

Water year is the 12-month period October 1 through September 30, and is named for the year in which it ends. 


\title{
Determination of Baseline Periods of Record for Selected Streamflow-Gaging Stations in and near Oklahoma for use in Modeling Applications
}

\author{
By Rachel A. Esralew
}

\section{Abstract}

Use of historical streamflow data from a least-altered period of record can be used in calibration of various modeling applications that are used to characterize least-altered flow and predict the effects of proposed streamflow alteration. This information can be used to enhance water-resources planning. A baseline period of record was determined for selected streamflow-gaging stations that can be used as a calibration dataset for modeling applications. The baseline period of record was defined as a period that is least-altered by anthropogenic activity and has sufficient streamflow record length to represent extreme climate variability. Streamflow data from 171 stations in and near Oklahoma with a minimum of 10 complete water years of daily streamflow record through water year 2007 and drainage areas that were less than 2,500 square miles were considered for use in the baseline period analysis.

The first step to determine the least-altered period of record was to evaluate station information by using previous publications, historical station record notes, and information gathered from oral and written communication with hydrographers familiar with selected stations. The second step was to indentify stations that had substantial effects from upstream regulation by evaluating the location and extent of dams in the drainage basin. The third step was (a) the analysis of annual hydrographs and included visual hydrograph analysis for selected stations with 20 or more years of streamflow record, (b) analysis of covariance of double-mass curves, and (c) Kendall's tau trend analysis to detect statistically significant trends in base flow, runoff, total flow, and base-flow index related to anthropogenic activity for selected stations with 15 or more years of streamflow record.

A preliminary least-altered period of record for each stream was identified by removing the period of streamflow record when streams were substantially affected by anthropogenic activity. After streamflow record was removed from designation as a least-altered period, stations that did not have at least 10 years of remaining continuous streamflow record were considered to have an insufficient baseline period for modeling applications.
An optimum minimum period of record was determined for each of the least-altered periods for each station to ensure a sufficient streamflow record length to provide a representative sample of annual climate variability. An optimum minimum period of 10 years or more was evaluated by analyzing the variability of annual precipitation for selected 5-, 10-, 15-, 25-, and 35-year periods for each of 20 climate divisions that contained stations used in the baseline period analysis. The distribution of annual precipitation was compared for each consecutive overlapping 5-year period to the period 1925-2007 by using a Wilcoxon rank-sum test. The least-altered period of record for stations was also compared to the period 1925-2007 by using a Wilcoxon rank-sum test. The results of this analysis were used to determine how many years of annual precipitation data were needed for the selected period to be statistically similar to the distribution of annual precipitation data for a long-term period, 1925-2007. Minimum optimum periods ranged from 10 to 35 years and varied by climate division.

A final baseline period was determined for 111 stations that had a baseline period of at least 10 years of continuous streamflow record after the record-elimination process. A suitable baseline period of record for use in modeling applications could not be identified for 58 of the initial 171 stations because of substantial anthropogenic alteration of the stream or drainage basin and for 2 stations because the least-altered period of record was not representative of annual climate variability. The baseline period for each station was rated "excellent", "good", "fair", "poor", or "no baseline period." This rating was based on a qualitative evaluation of the approximate degree of basin alteration for the least-altered period of record, and whether or not the least-altered period was long enough to be representative of long-term climate variability. Baseline periods of record were rated as "excellent" for 22 stations, "good" for 42 stations, "fair" for 24 stations, and "poor" for 23 stations.

\section{Introduction}

Managing rivers and streams to maintain physical, chemical, and biological integrity is a challenge for resource 
managers in Oklahoma and nationwide. Knowledge of how anthropogenic activity and climate change affect the flow regime can be helpful for water supply regulation and planning. Currently (2010), the Oklahoma 50-Year Comprehensive Water Plan requires development of stream water allocation models to predict how proposed alterations may affect water supply for consumptive and nonconsumptive uses (Robert S. Fabian, Oklahoma Water Resources Board, oral and written commun., July 2008). These models are part of the process for development of a water-permitting policy for Oklahoma.

The use of historical streamflow data from a least-altered period of record can enhance water resources planning. These data can be used to calibrate various modeling applications that are used to characterize unregulated flow and predict the effects of proposed streamflow alteration. Streamflow data commonly are needed from streams that are difficult or costprohibitive to gage. Streamflow can be estimated for many ungaged stream locations by using digital watershed or regression models. The following are examples of frequently used digital watershed modeling applications in which verification or calibration by using long-term data from streamflow-gaging stations (referred to as "stations" in this report) are required: Hydrologic Simulation Program-Fortran (HSPF) (Donigan and others, 1984), Spatially Referenced Regresssion on Watershed Attributes (SPARROW) (Preston and others, 2009), Precipitation Runoff Modeling System (PRMS) (Leavesley and others, 1983), MIKE_11 [Havnø and others, 1995], and TOPMODEL [Wolock, 1993]). Regression models often are used to estimate flow statistics at ungaged stream locations (for example, the U.S. Geological Survey, StreamStats program, U.S. Geological Survey, 2009a), and many regression applications require use of a least-altered period of streamflow data (or streamflow record) for model calibration (Esralew and Smith, 2009). A least-altered period of streamflow record was used to create the U.S. Geological Survey (USGS) Hydroecological Integrity Assessment Process for Oklahoma (HIP) (Turton and others, 2009). This model can be used to estimate how proposed flow alteration may affect flow parameters that are vital to aquatic ecological function. For this report, continuous streamflow data from streamflow gaging-stations are referred to as "streamflow record" and a specified period during which continuous daily streamflow data are calculated is referred to as a "period of record".

Ideally, modeling applications that use data from stations to characterize unaltered flow need to include data from a long-term period of record. This period of record should reflect the least-altered condition of streamflow available. Demand for water increases with population, urban, and agricultural development increases, and increasing recreational use. Typical anthropogenic activity that affects streamflow may include streamflow regulation, irrigation, diversion and groundwater withdrawal for industrial and consumptive water supply, effluent discharge, and urban development (Stankowski 1972; Fitzpatrick and others, 1999; Konrad and Booth, 2002; Smith and Wahl, 2003).
The unpredictable nature of current and future patterns in climate also can affect streamflow. Streamflow data have been collected for streams in and near Oklahoma during periods ranging from a few years to nearly a century (USGS National Water Information System, http://waterdata.usgs. gov/nwis, accessed November 1, 2007). The least-altered period of record for some stations (referred to in this report as the "least-altered period") may be short because of few streamflow data and an increase in urban or agricultural development of a stream with time. Shorter periods of record may coincide with aberrant climate and streamflow patterns that are not considered typical. Longer periods of record are more likely to provide a representative sample of central tendencies and variability of streamflow. A sufficient streamflow record length (at least 10 years, for example) would likely increase the probability that variability of the daily hydrograph, caused by recurrent climate cycles, is included in the streamflow data used for model calibration. Therefore, longer periods of streamflow record can help to minimize statistical bias and random error in modeling applications.

A baseline period of record (referred to in this report as a "baseline period") may be determined for stations with a sufficient streamflow record. The baseline period can be defined as a period in which streamflow is least-altered by anthropogenic activity and has sufficient streamflow record length to represent annual climate variability. By this definition, some stations cannot be assigned a baseline period because streamflow at these stations is substantially altered or the length of the period of record is short. To address the need for a least-altered period of record for use in modeling applications and water-resources planning, the USGS, in cooperation with Oklahoma State University and the Oklahoma Water Resources Board, conducted a study to determine baseline period of record for selected streamflow-gaging stations in and near Oklahoma.

Streamflow at few if any streams in or near Oklahoma have been completely free of alteration from anthropogenic activity during the last century. Therefore, streamflow record that includes effects from anthropogenic alteration must be included in evaluation of Oklahoma streamflow to obtain a sufficiently long-term period of record representative of streamflow during varied climate. The goal of the baseline period determination process, in Oklahoma, is to select, for each station, a sufficiently long period that is "leastaltered." The period of streamflow data, in which the degree of alteration is substantially high, can be eliminated from inclusion in a baseline period. The degree of anthropogenic alteration may vary spatially and temporally. Subjective decisions may be involved in the process to determine if a period is "altered". Examples of such change include increased irrigation during a period of time, continued construction of many small flood retarding structures, or urbanization of a drainage basin.

Substantial streamflow alteration can be caused by a variety of human activities. Consumptive water uses are common throughout Oklahoma, including irrigation, livestock, 
and public water-supply from surface-water and groundwater sources (Tortorelli, 2009).

Many surface-water sources for water-supply in Oklahoma are from reservoirs or other impoundments (Tortorelli, 2009). Flood-peak reduction also affects streamflow for large areas of Oklahoma, mainly from many floodwater-retarding structures that serve to decrease main-stem flood peaks and regulate the rate of runoff recession (Bergman and Huntzinger, 1981; Tortorelli and Bergman, 1985). Substantial regulation of streamflow from reservoirs and other impoundments can alter the magnitude, frequency, and duration of streamflow, depending on the intended water use and the extent of the regulation. Specifically, regulation can alter the seasonal flow regime, decrease the magnitude and frequency of flooding, increase the duration and frequency of zero-flow and low-flow periods, and decrease long-term average flows downstream (Tortorelli and Bergman, 1985).

Most irrigation water used in Oklahoma comes from groundwater, most of which comes from the High Plains Aquifer in western Oklahoma. Groundwater also is used for municipal public water supply, livestock, and oil and gas development (Tortorelli, 2009). Groundwater withdrawals in the drainage basin of a stream can affect streamflow through reduction of base flow or alteration of base-flow patterns (Wahl and Tortorelli, 1997).

Quality assurance and examination of outliers in modeling applications may require a qualitative assessment of the data used to calibrate the model. A quality ranking can be assigned to each baseline period to reduce the subjectivity of data selection and comparison. For example, terms such as "excellent", "good", "fair", and "poor", can be assigned to the period of record on the basis of the degree of anthropogenic activity, severity of climatic bias for the period with the least anthropogenic activity, and length of the streamflow record. In this scenario, selection of a baseline period for each stream would be a period with the most favorable quality ranking based on these criteria.

\section{Purpose and Scope}

This report describes the process used to determine baseline periods of record for selected stations in and near Oklahoma with more than 10 years of continuous streamflow data. The baseline period determination process included identification of a least-altered period and the minimum number of years to reflect climate variability.

This report documents the methods used to select the least-altered period that include (1) analysis of historical information about stations and basins, (2) assessment of the change in the area upstream from dams in the basins, and (3) visual and statistical trend analysis to determine the year when anthropogenic activity may have altered streamflow. The process used to determine an optimum minimum number of years for a least-altered period to be considered baseline is described. The optimum minimum number of years is based on the minimum time period required to represent annual variability of climate. Also described is the process used to determine a quality ranking for each baseline period. The final baseline period and quality ranking determined for streamflow record at selected stations is presented.

\section{Selection of Data for Analysis}

Streamflow data from 171 stations in and near Oklahoma were considered for use in the baseline period analysis (fig. 1). These stations had a minimum of 10 complete water years of daily streamflow record through water year 2007 and a drainage area that was less than 2,500 square miles (fig. 1). Daily mean streamflow data for USGS stations in Oklahoma and adjacent states are available on the World Wide Web (URL http://waterdata.usgs.gov/ok/nwis/ and http://waterdata.usgs. gov/us/nwis). Ten years of continuous streamflow record was assumed to be the minimum required for defining the leastaltered period. This assumption was based on the use of a minimum of 10 years of streamflow record for computation of long-term streamflow statistics in Oklahoma (Heimann and Tortorelli, 1988; Tortorelli, 2002; Lewis and Esralew, 2009). Gaps in the continuous streamflow record were accepted as long as the total streamflow record equaled or exceeded 10 complete water years.

Stations selected for baseline period analysis include only those in which the drainage area to that station is completely in 8-digit hydrologic unit (HU) boundaries that are in Oklahoma or touch the Oklahoma state border (fig. 1). These criteria were required because basin-characteristic data were not readily available for stations with drainage basins that extend outside of this area (Smith and Esralew, 2009). Basin characteristic data were used to determine the extent of regulation that was part of the process used to determine the least-altered period (see section titled "Evaluation of Basin Regulation to Eliminate Nonbaseline Years and Refine Preliminary Least-Altered Periods"). Stations selected for the baseline period analysis only included stations in which the drainage area was less than 2,500 square miles. For this report, drainage area sizes greater than 2,500 square miles were considered substantially large, which is the same criteria for drainage-area size defined in a previous study (Tortorelli, 1997). Stations with drainage areas larger than this size are more difficult to analyze for a least-altered period because of the challenge in identification of a potentially large range of anthropogenic activities that may affect streamflow in large basins. Analysis of station records with drainage areas of this size was beyond the scope of this study. Analysis of station records along main stems of the largest river systems in the state (the Arkansas, Canadian, Neosho, Red, and Verdigris Rivers; and lower parts of the Cimarron, North Canadian, and Washita Rivers) was not considered for this report because the drainage areas were greater than 2,500 square miles or extend outside of the study area. 


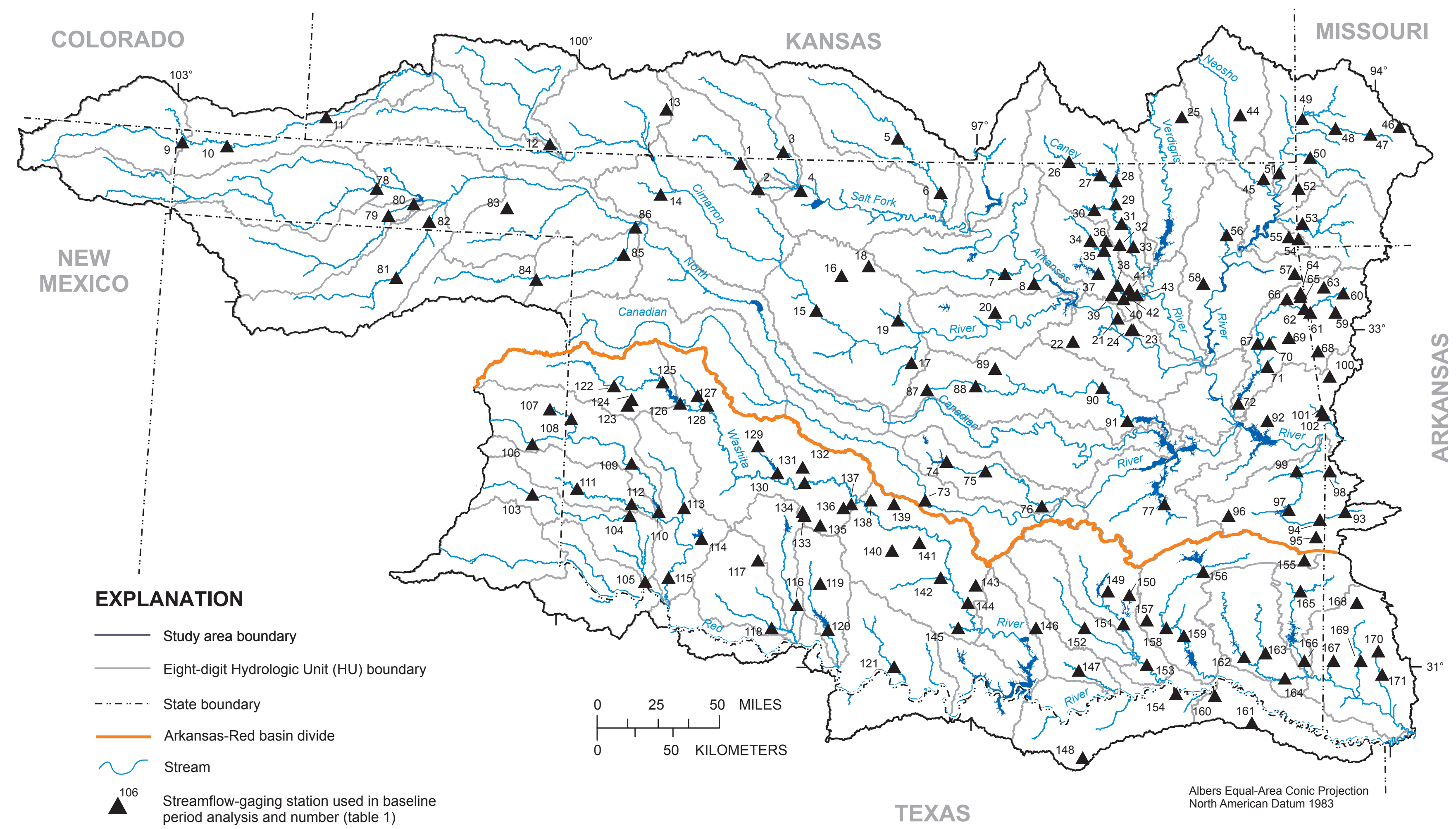




\section{Methods Used to Determine the Baseline Period of Record}

The process used to determine the baseline period for each station was completed in two phases. An overview of the processes used to determine the baseline period is in figure 2 with notation of the table in which the results are presented.

A least-altered period was determined for each station in the first phase of the analysis. A least-altered period for a station is the continuous period that remained after eliminating years altered by anthropogenic activities. The first phase was divided into three steps each of which was used to determine and evaluate potential anthropogenic alteration that may affect streamflow. First, historical station information was evaluated from previous publications, record notes, and oral and written communication. Second, stations wth streamflows that were substantially affected from upstream dams were identified by determining the location and extent of dams in the drainage basin, and the percentage of the drainage basin upstream from dams. Third, visual and statistical trend analysis was used for selected stations with 20 or more years of continuous streamflow record to detect statistically significant changes in base flow, runoff, total flow, and base-flow index that might be attributable to anthropogenic alteration. During each step, streamflow record from the station in which anthropogenic activity was suspected to alter streamflow was either removed from consideration for the least-altered period or the quality rank that described the least-altered period was adjusted accordingly.

An optimum minimum period of record was determined for stations in each Climate Division (National Oceanic and Atmospheric Administration, 2008) in the second phase of the analysis (fig. 3). Climate divisions are considered regions that are homogeneous with respect to climate and hydrologic conditions (National Oceanic and Atmospheric Administration, 2008). Statistical analysis of annual precipitation data was used to determine whether 10 years of streamflow record sufficiently represented long-term climate variability.

\section{Determination of Least-Altered Period of Record}

The methods used to determine the least-altered period are described in this section. These methods comprise the first phase of the process used to determine a baseline period.

\section{Analysis of Historical Station and Basin Information to Eliminate Nonbaseline Years and Define Preliminary Least-Altered Period of Record}

Historical basin information was used to eliminate streamflow record during nonbaseline years from selected stations to identify a preliminary least-altered period. Historical information about each station was obtained from previous USGS publications (Heimann and Tortorelli, 1988; Wahl and Tortorelli, 1997; Tortorelli, 2002; Smith and Wahl, 2003; Tortorelli and others, 2005; U.S. Geological Survey, 2008; and Lewis and Esralew, 2009), from information provided by hydrographers at the USGS Oklahoma Water Science Center, and from information gathered from historical station records filed at the USGS Oklahoma Water Science Center (table 1, back of report).

Annual reports (U.S. Geological Survey, 2008) and hydrographer records typically included comments about suspected anthropogenic activities that might affect the streamflow. These activities included information about regulation, diversion, irrigation, and sewage effluent discharge. Groundwater withdrawals in the drainage basin were difficult to document because of scarce historical groundwater-use data availability in Oklahoma (Robert L. Tortorelli, U.S. Geological Survey, oral commun., August 2008). In addition, some comments were subjective because of the inconsistency with which a hydrographer might choose to document observations pertaining to human activities in the basin. A preliminary least-altered period was determined for each station on the basis of evaluation of all available historical information.

If substantial anthropogenic activity began from a known date during the period of record, then the period before that date was considered for the preliminary least-altered period. For example, authors of previous publications consider a basin to be substantially regulated if 20 percent or more was affected by regulation (Heimann and Tortorelli, 1988, Tortorelli 2002; Lewis and Esralew, 2009). This criterion was used to eliminate nonbaseline years from the period of record that could not be considered least-altered or eliminate stations that did not have a least-altered period suitable for a baseline period. If less than 10 years of streamflow record for a given station were not substantially affected by anthropogenic activity, then all data from the station was eliminated from consideration as a baseline period. Quality rankings were assigned for each preliminary least-altered period on the basis of professional judgment.

The methods for this step are limited to use of available historical information in record notes. Examples of anthropogenic activities in Oklahoma that may affect streamflow but may not have been documented in the historical record include regional irrigation and other agricultural activities (Tortorelli, 2009), water-use for shale-gas well hydraulic fracturing (Schein, 2008), and clear-cutting from logging operations in southeastern Oklahoma (Howell and Johnson, 2003). Although water-use assessments for Oklahoma were reported in previous studies by 4-digit HU, by major aquifer, and on a statewide basis (Tortorelli, 2009), historical water-use estimates are not well documented at the drainage-basin level. Incorporation of this information into the least-altered period determination process was

beyond the scope of this report; however, further investigation into historical water-use at the drainage-basin level may be useful for refinement of the least-altered period of record. 


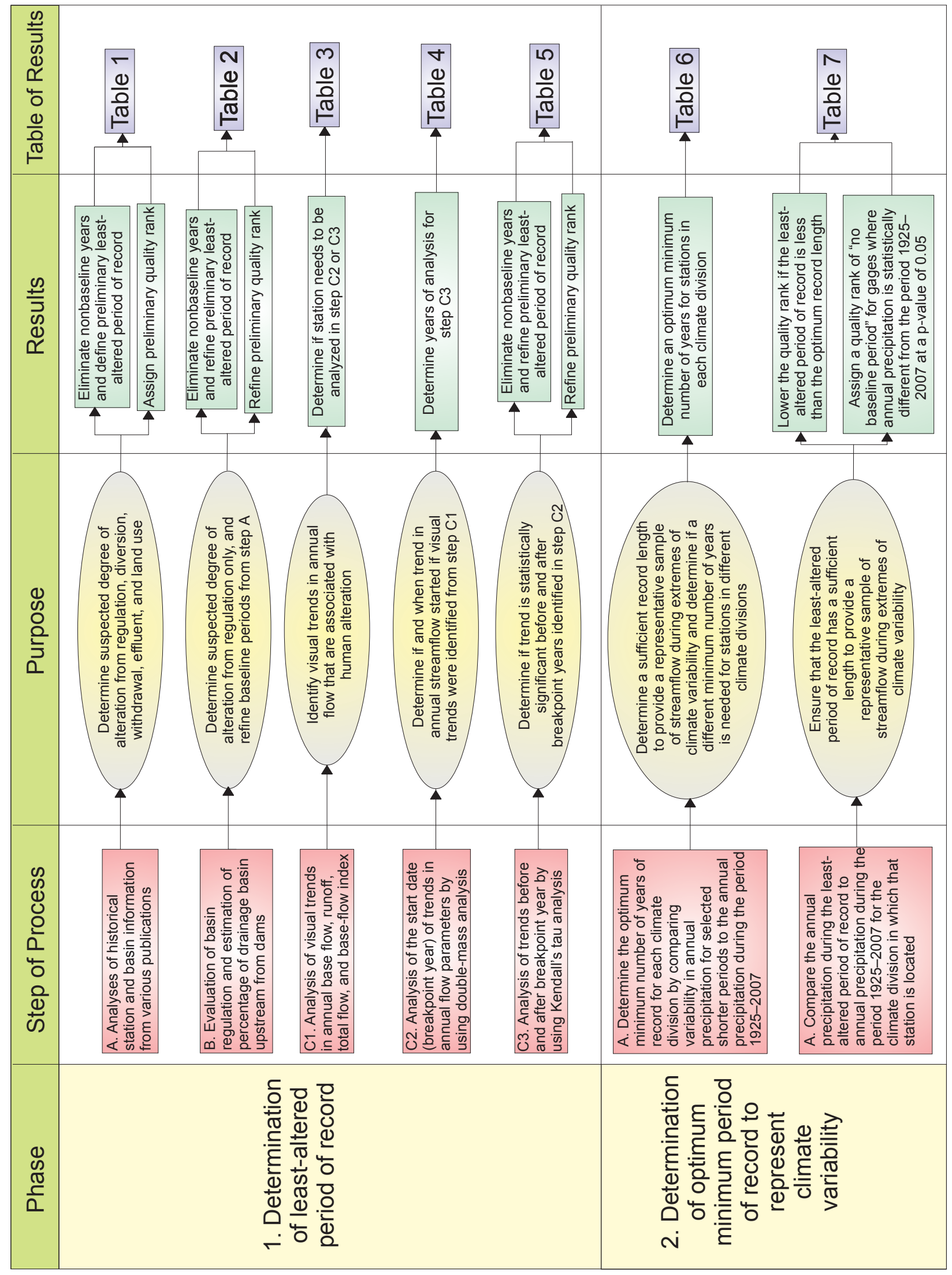

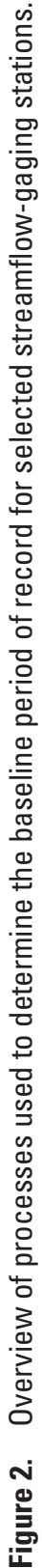


A

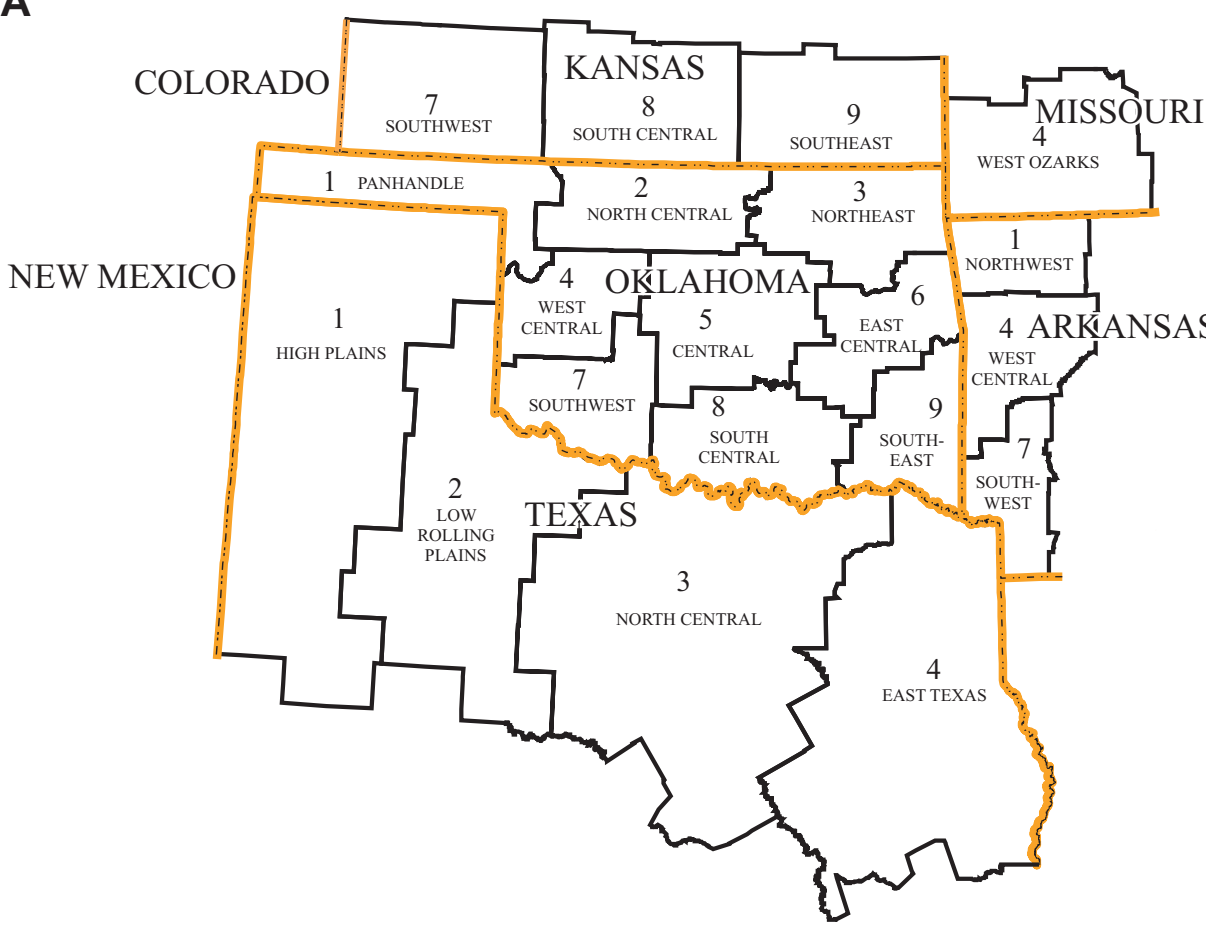

\section{EXPLANATION}

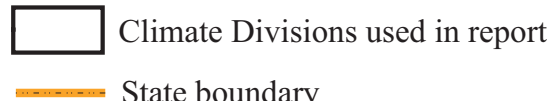

OK-9 Climate Division code and name

SOUTH- (National Oceanic and Atmospheric

EAST Administration, 2009)

Figure 3. National Weather Service Climate Divisions used in annual precipitation analysis.

\section{Evaluation of Basin Regulation to Eliminate Nonbaseline Years and Refine Preliminary Least- Altered Periods}

The purpose of this step was to further evaluate the extent of regulation in the drainage basins for stations that were analyzed in the previous step. Although previous publications identified whether or not streamflow at a station was regulated by dams affecting 20 percent or more of the drainage basin, (Heimann and Tortorelli, 1988; Tortorelli, 2002; Lewis and Esralew, 2009), or 10 percent or more of the basin (Long and others, 2004), little was documented regarding less extensive (minor) regulation in the basin. Even minor regulation from dams and other impoundments may affect the streamflow regime depending on the rate of withdrawals and management of releases. The extent of regulation, as indicated by the number of dams in the drainage basin, was analyzed for stations that had at least 10 years of least-altered continuous streamflow record as determined from the previous step. For these stations, each drainage basin was delineated by using ArcInfo software (Environmental Systems Research Institute, Incorporated, 2007). The U.S. Army Corps of Engineers National Inventory of Dams (NID) (U.S. Army Corps of Engineers, 2008) and the Oklahoma Water Resources Board Oklahoma Water Atlas (Vance, 2007) were used to locate dams in the drainage basin. Uses for these dams include flood control, public-water supply, hydropower, recreation, and agricultural uses (irrigation supply and farm impoundments). The drainage area upstream from the dams was determined and the percentage of the total drainage area for the station that was affected by dams was calculated. Only dams with certain characteristics were considered in the analysis. Dams were considered in this analysis if the dams had (1) an upstream drainage area of at least 9,700 square feet, (2) were classified as (a) a dam with high or substantial hazard potential, (b) were classified as a dam with a low-hazard potential that exceeds 25 feet in height and 15 acre-feet storage or (c) were classified as a dam with low-hazard potential that exceeds 50 acre-feet storage and is at least 6 feet high, (U.S. Army Corps of Engineers, 2008), and (3) had a documented year of completion. The dam locations were verified by using National Agriculture Imagery Program (NAIP) 2003 or 2006 color aerial photography (U.S. Department of Agriculture, 2008) and U.S. Geological Survey 7.5-minute, 1:24,000 scale topographic map quadrangles (U.S. Geological Survey, 2009b).

Many small farm impoundments are constructed for domestic or small-scale use. The dams that form these impoundments were often difficult to locate, or were not on drainages that met the size requirement for accurate delineation, and were omitted from analysis. Therefore, estimates of area upstream from dams presented in this report most likely underestimate the total drainage area affected by regulation. However, the drainage area upstream from farm impoundments is typically small when compared to the total drainage area upstream from the stations in this report. The farm impoundments in drainage areas of stations that were 
considered in this analysis (farm impoundments that could be located and met the drainage area requirements for delineation) had drainage-basin areas that ranged from 0.25 acre to 14 square miles, and had an average drainage area of 0.7 square mile. The average drainage area for stations considered for this step was 559 square miles.

The year that a dam was completed was used to construct a time-series plot of drainage area upstream from dams. Nested dams, or dams that are upstream from other dams, were not included in the computation if the year of completion of the nested dam was after that of a dam that was downstream. As an example, figure 3 shows the percentage of the drainage area at Washita River near Clinton (07325000) that was affected by impoundment with time.

The least-altered period was refined from the previous steps by either (1) excluding years in which the drainage areas upstream from dams ranged from 1 percent to 20 percent of the drainage area if at least 10 years of streamflow record remained after the years were excluded, or (2) modification of the quality rank for the least-altered period.

Streamflow record in which more than 20 percent of the drainage area was upstream from dams was removed from consideration for the least-altered period and if less than 10 years remained, then the streamflow record for the station was not considered suitable as a baseline period. Visual inflections in the plots of drainage area upstream from dams with time were used to locate a time period in which increases in the area upstream from dams were visually prominent. This analysis was done for stations that had 10 or more years of streamflow record in which regulation affected less than 20 percent of the drainage area. The year prior to the inflection point was used as the end year for the new least-altered period. If the percentage of the drainage area upstream from dams was gradual with time, an incremental procedure was used. The year prior to the year when 10,15 , or 20 percent of the drainage basin was upstream from dams was selected as the end year for the new least-altered period. A preference was given to lower percentages of drainage area upstream from dams, if the resulting streamflow record length after data elimination was at least 10 years. Drainage basins in which less than 1 percent of the drainage area was upstream from dams were assumed to have no notable regulation and remarks were noted (table 2, back of report). Drainage basins in which less than 5 percent of the drainage area was upstream from dams were considered to have minor regulation. However, the least-altered period was not reduced on the basis of this criteria. Instead, the quality ranking was adjusted. This approach was used to avoid excessive elimination of least-altered years based on a minor amount of regulation.

The preliminary quality ranking was adjusted on the basis of the degree of alteration indicated by historical records and the extent of the drainage area upstream from dams. The remaining period of record was re-assessed to determine if a known alteration from historical information was indicated from the previous step of the analysis. If no known alteration was indicated during the remaining period, the following procedures were used to determine the preliminary quality ranking: (1) if the resulting least-altered period for a station included a period in which 1 to 5 percent of the drainage area was upstream from dams, then the quality rank was changed to "good", (2) if the drainage area upstream from dams was between 5 and 10 percent it was changed to "fair", or (3) if the drainage area upstream from dams affected an area greater than 10 percent and less than 20 percent of the drainage basin, the rank was changed to "poor".

The quality rank was adjusted by using professional judgment for stations in which streamflow record elimination was performed and additional indications of alteration were apparent from historical information. For example, if the remarks from the previous step pertained to regulation (such as diversions for water supply), then the quality rank was not adjusted again. Some periods of streamflow record were eliminated from further consideration because of substantial historical alteration not related to regulation (such as groundwater pumping or sewage effluent).

An example of this procedure is demonstrated for Washita River near Clinton, with a period of record of 19362007 (fig. 4). Previous publications and historical information indicate that this station has been regulated by Foss Reservoir since 1961 (Lewis and Esralew, 2009). Prior to 1961, streamflow at the station was regulated by many upstream floodwater-retarding structures that affected less than 20 percent of the drainage area (Heimann and Tortorelli, 1988; Tortorelli, 2002; Lewis and Esralew, 2009), but the extent of this regulation was unavailable in existing documentation. The drainage area consists of more than 1 percent drainage area upstream from dams since 1931, more than 5 percent drainage area upstream from dams since 1952, more than 10 percent drainage area upstream from dams since 1956, and a little less than 20 percent drainage area upstream from dams since 1960 just prior to the construction of Foss Reservoir. The change from 1 percent to less than 20 percent drainage area upstream from dams represents a gradual increase with time. Because at least 10 years of streamflow record were available in which less than 10 percent of the drainage area was upstream from dams, the least-altered period was reduced to the period prior to 1956. As a result, the preliminary least-altered period for this station was 1936-1955, and the quality rank was assigned as "fair".

\section{Visual Trend Analysis and Double-Mass Analysis of Annual Streamflow to Eliminate Nonbaseline Years and Refine Preliminary Least-Altered Period}

Additional analysis of annual streamflow record was used to test whether the qualitative indicators of alteration determined in previous steps had an observable effect on the annual streamflow regime. In order to further eliminate nonbaseline years and better define the least-altered period, a statistical approach was used for selected streams to detect if substantial changes in annual streamflow patterns might be associated 

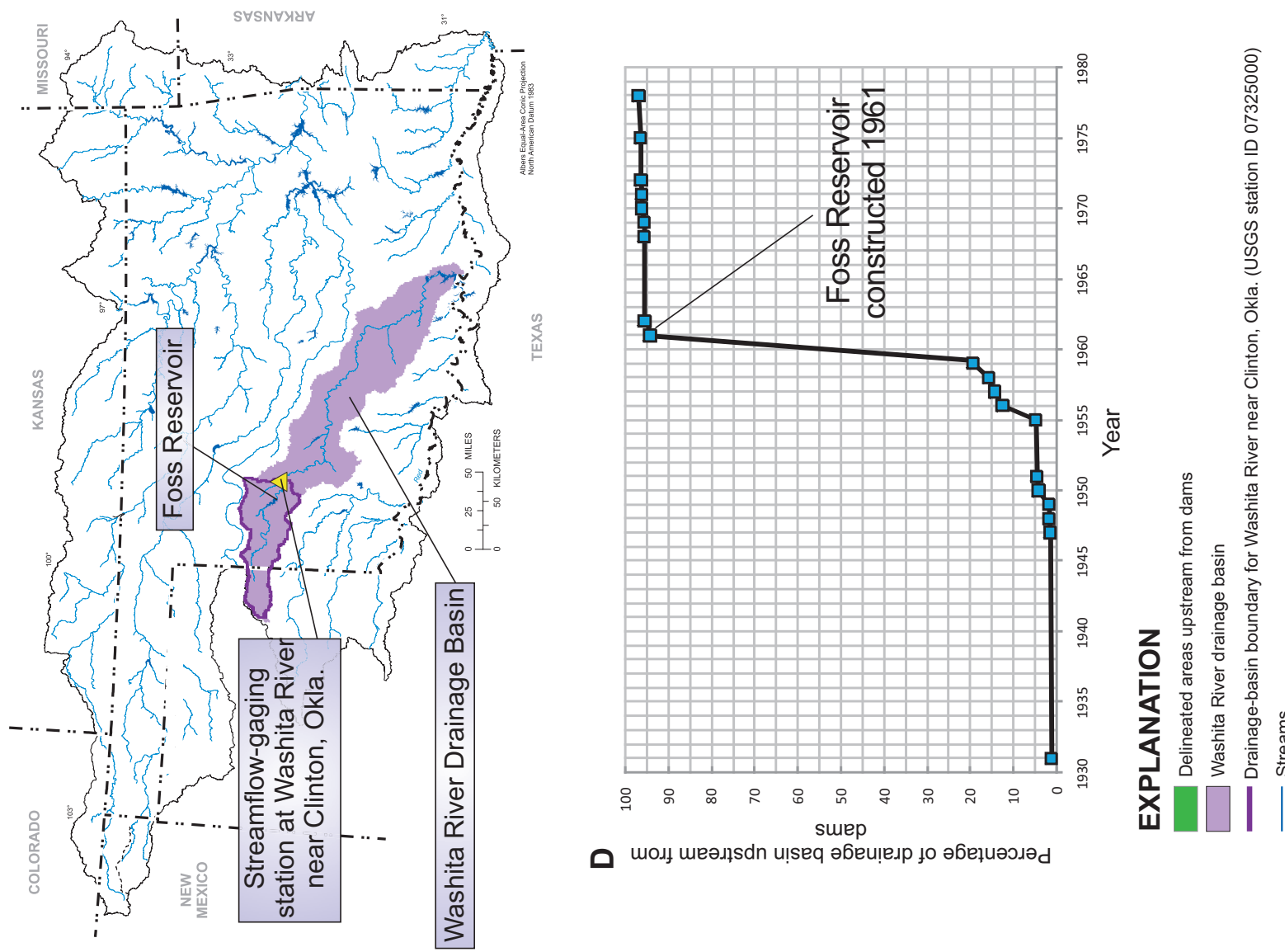

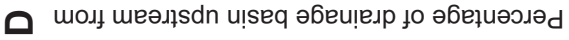
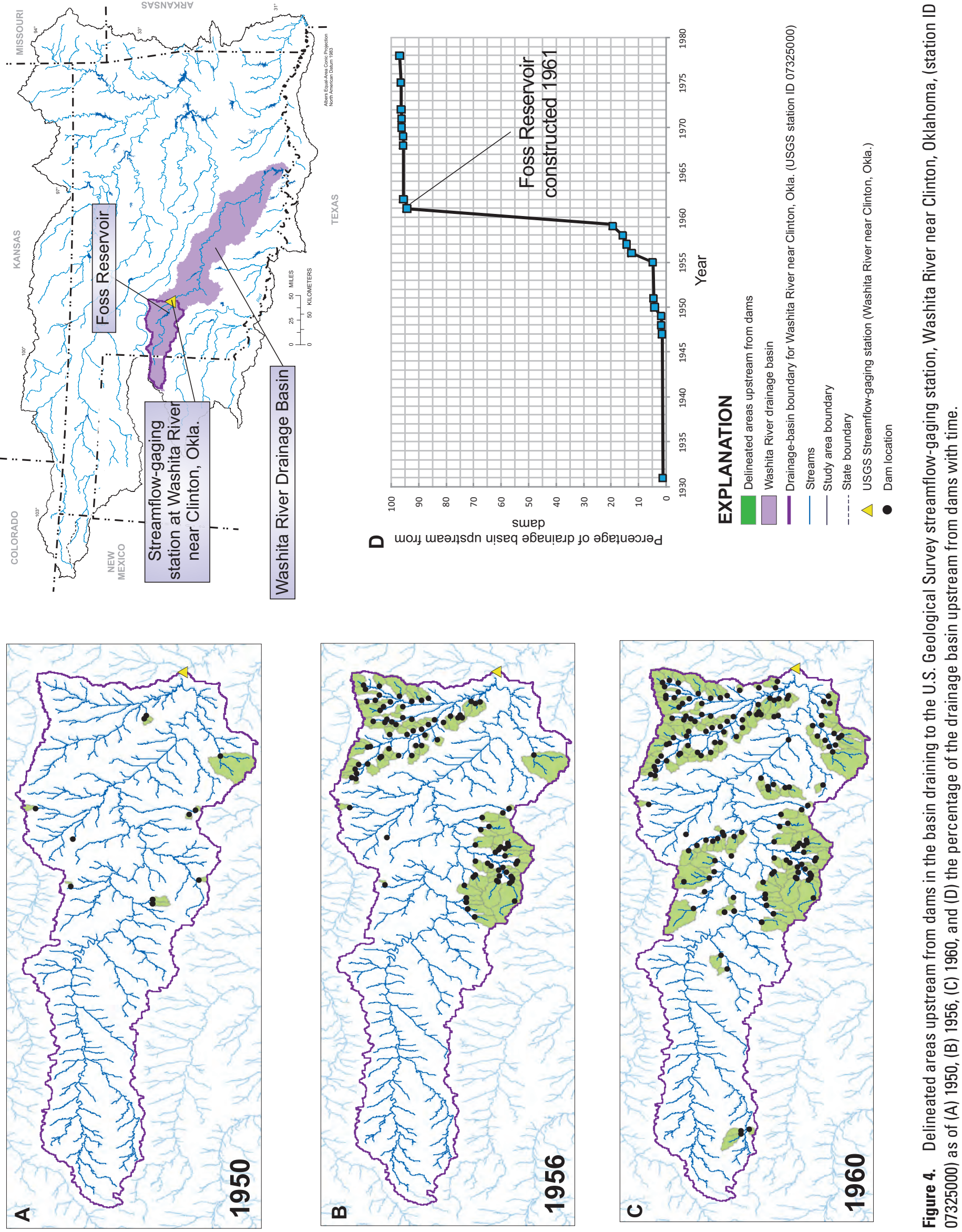
with anthropogenic activity during the preliminary leastaltered periods. This analysis was used to detect any additional changes in the basin during the preliminary least-altered period that were not accounted for in historical information or the analysis of the extent of regulation as indicated by the number of dams in the drainage basin.

Statistical trend analysis of annual base flow in inches, annual total flow in inches, annual runoff in inches, and annual base-flow index (the ratio of base flow to total flow) was used. Trends in annual base flow, runoff, total flow, and base-flow index may indicate large-scale anthropogenic alteration to a stream or in a drainage basin. Downward trends in base flow, runoff, and total flow might indicate that direct surface-water withdrawals are increasing in the basin. Downward trends in base flow also may indicate that the magnitude and extent of groundwater withdrawals are increasing in the basin. An upward or downward trend in base-flow index may indicate an increase in surface-water or groundwater withdrawals, or a change in the way that water is being withdrawn. Upward trends in base flow and base-flow index may indicate that streams are receiving irrigation returns, or that infiltration is increasing in the basin. Infiltration in the drainage basin may happen because of an increasing number of impoundments in the drainage basin that may induce recharge, or because of increasing precipitation in the drainage basin caused by climate change.

\section{Visual Trend Analysis and Selection of Stations for Further Statistical Analysis}

Annual base flow, runoff, total flow, and base-flow index were calculated from daily mean streamflow record by using the Base-Flow Index program (Institute of Hydrology, 1980; Wahl and Wahl, 1995). Annual plots of these parameters for stations that had at least 20 years of streamflow record were created and visually analyzed to identify potential changes in streamflow. If a noticeable change in any of the annual streamflow parameters were detected, then the station was further considered for statistical trend analysis. If no noticeable change in annual streamflow parameters were detected, then an assumption was made that there would be no statistical trend; therefore, a statistical trend test was not performed. This assumption was made to reduce the need to perform statistical analysis on data from a large number of stations and increase efficiency of the analysis procedures.

Even though 10 years of streamflow record can be considered adequate for a baseline period, for this report, 10 years was not considered an adequate streamflow record length to draw conclusions from trends caused by anthropogenic activities during the least-altered period. Usage of only 10 years of streamflow record in visual and statistical time-based trend analysis may be misleading because of insufficient data. For example, if a 10-year period contains a climate cycle that includes wet and dry periods, but starts in a dry period and ends in a wet period, this cycle may be mistaken for a trend caused by human activities rather than climate. For these reasons, 20 years of streamflow record were selected as a minimum number of years for visual trend analysis. If less than 20 years of streamflow data were available prior to the start of substantial regulation or known irrigation (Wahl and Tortorelli, 1997), visual trend analysis was not performed. If the station had 20 years or more of streamflow data available prior to the start of substantial regulation or irrigation, only those 20 years or more of data were analyzed.

Upward trends observed from inspection of data plots at many stations indicated that base flow and runoff increased in the early to mid-1980s. Concensus from literature and precipitation data from the early to mid-1980s to around the year 2000, indicated much of the state experienced an unprecedented wet period (Garbrecht and Schneider 2007; Oklahoma Climatological Survey, 2007; Oklahoma Water Resources Board, 2007). For this report, the period between 1980 and 2000 is referred to as the "wet period" with respect to annual precipitation. An observed upward trend in base flow, runoff, or total flow, or any observed trend in base-flow index, during this the wet period was assumed to be caused by climate rather than anthropogenic activity. In this case, the span of the leastaltered period was not reduced, and further analysis was not needed to refine the least-altered period.

\section{Analysis of Covariance of Double-Mass Curves}

Analysis of covariance of double-mass curves (Searcy and Hardison, 1960) was used as an additional tool to determine whether changes in streamflow characteristics, not related to climate variability, could be detected. A doublemass curve is a 2-dimensional linear plot of the cumulative data value of one variable over the cumulative data value of a second variable during coincident years (fig. 5). For this analysis, annual streamflow (annual base flow, annual runoff, and annual total flow) at the test station was plotted along the $\mathrm{x}$-axis, and annual precipitation, during the same year, was plotted along the y-axis.

An abrupt change in the slope of the double-mass curve, referred to as a "breakpoint," indicates a change in hydrologic conditions at the test station and the year of breakpoint can be interpreted as an appropriate end of the least-altered period. An assumption was made that a change in the relation between streamflow and precipitation at the test station is observed when plotted as a double-mass curve, that the change is caused by anthropogenic alteration of streamflow and not caused by a change or trend in climate. On the basis of these assumptions, a change in the streamflow trend with time may be caused by anthropogenic activity that has led to increased alteration of the streamflow regime.

Analysis of covariance (ANCOVA) of double-mass curves was performed for stations in which trends were visually detected that may be associated with anthropogenic activity. ANCOVA was used to test the significance of potential breakpoints on each double-mass curve, as described in Searcy and Hardison (1960). In this method, a variance-ratio test (or "F-test") (Snedecor, 1934) is used to determine the probability (p) that the null hypothesis of no difference among slopes of the line segments before and after the breakpoint can 


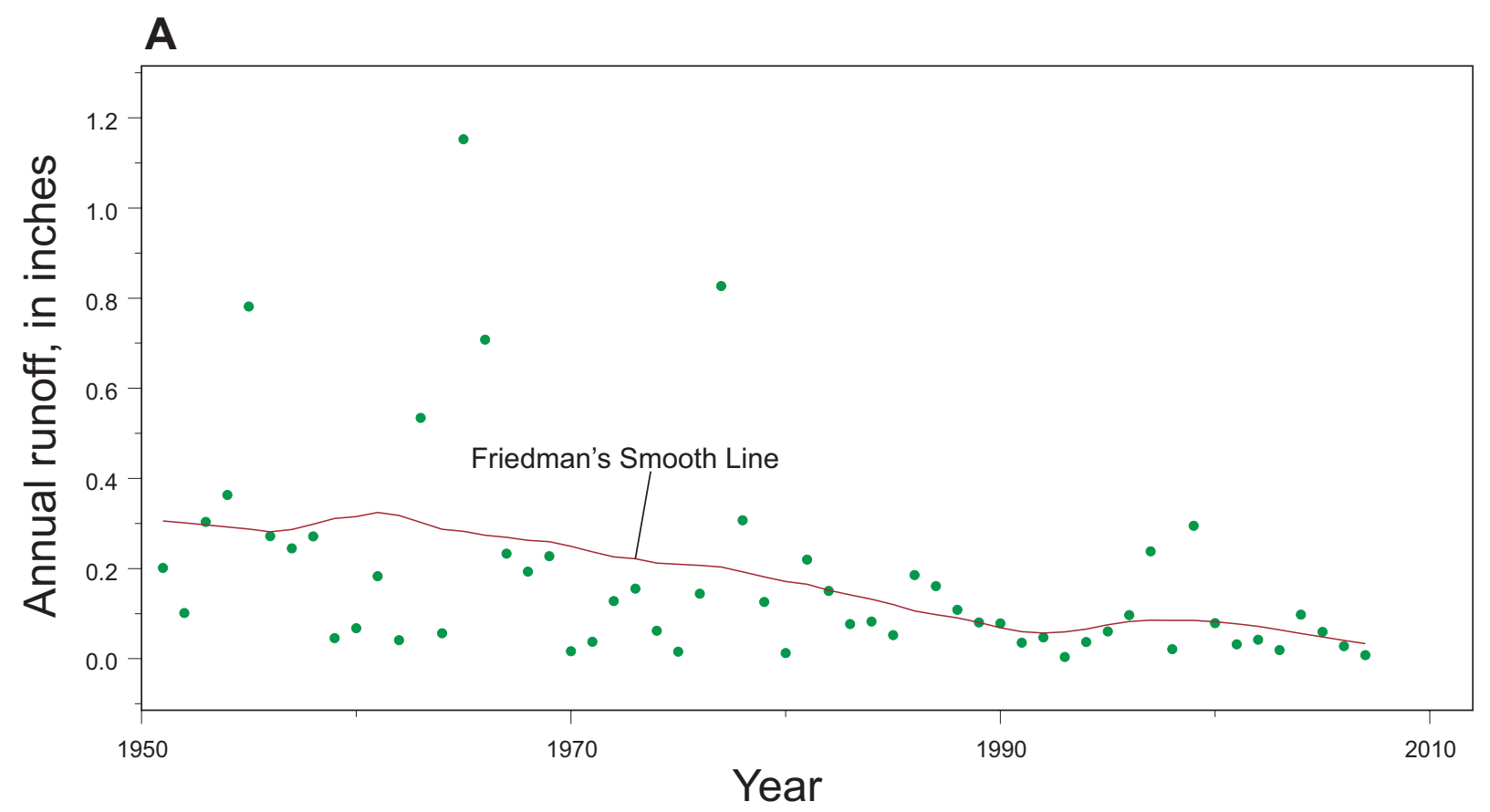

B

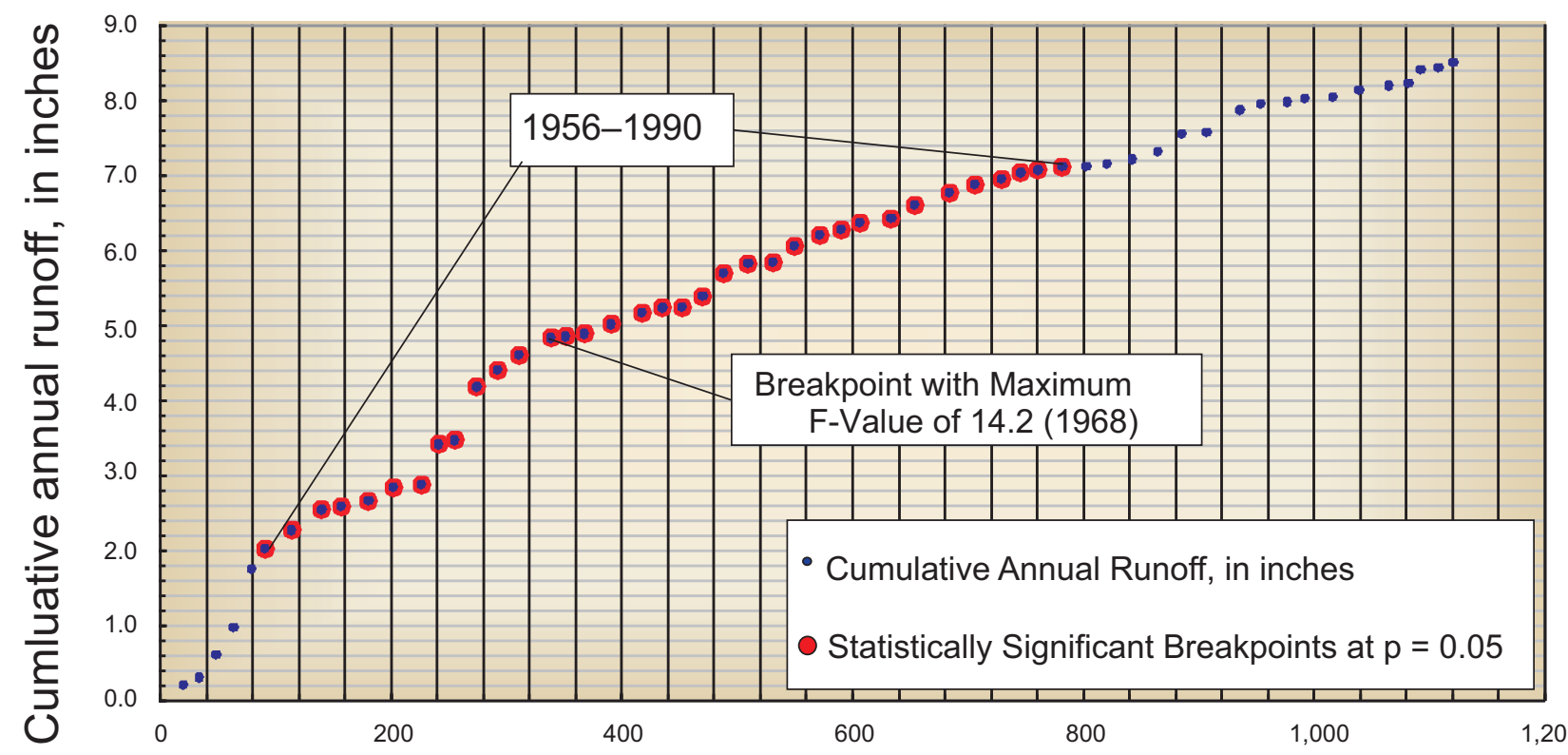

Cumulative annual precipitation, in inches

Figure 5. Example of (A) a time series plot of annual runoff and a Friedman's smooth trendline (Friedman, 1984), and (B) a doublemass curve for cumulative annual precipitation and cumulative annual runoff at Cimarron River near Kenton, Oklahoma, (USGS station identifier 07154500) showing breakpoints that indicate changes in the slope of the relation between precipitation and streamflow.

be rejected with a critical p-value less than or equal to 0.05 . Searcy and Hardison (1960) reported that the ANCOVA test can be applied after visually inspecting the double-mass curve to identify possible breakpoints.

Esralew and Baker (2008) reported that a minor breakpoint in the double-mass plot may be easy to overlook and may only identify those breakpoints that are the most visually evident. Visually evident breakpoints may not be the same as the breakpoint with the largest F-value, so a visually evident breakpoint may not be the strongest statistical breakpoint. Therefore, all points on each double-mass curve were tested as potential breakpoints, and slopes of the line segments 
before and after each point were compared. This step facilitated the interpretation of breakpoints that are not evident visually as single points but as gradual changes in slope. This interpretation may indicate, for example, which changes such as increases in farm impoundments or other basin irrigation activities are gradually altering streamflow characteristics.

Limitations apply to this approach that warrant careful consideration of the results from ANCOVA tests, which is discussed in Wigbout (1973). One notable limitation is the F-test is sensitive to variability (scatter) in each of the two line segments. The F-test compares the variability in annual streamflow among periods to the variability in annual streamflow in periods so comparing line segments with high coefficients of determination $\left(\mathrm{R}^{2}\right)$ may lead to the designation of a minor inflection in slope as significant (Searcy and Hardison, 1960; Wigbout, 1973; Esralew and Baker, 2008). Therefore, in addition to significance as determined by ANCOVA, visual inspection of double-mass curves, such as visual evaluation of slope changes and breakpoint prominence, were used to determine whether substantial changes in streamflow were indicated in years in which a breakpoint was identified.

Double-mass curves were created to relate annual baseflow, annual total-flow, and annual runoff to annual precipitation for the climate division for each station selected for analysis. Double-mass analysis was not performed for base-flow index data because the units (unitless ratio) are not the same as that for annual precipitation. All years in which the ANCOVA critical F-value ( $\mathrm{p}=0.05$ significance level) was exceeded were identified as possible breakpoints for each double-mass curve. Breakpoints were visually examined to determine whether statistically significant breakpoints most likely represented substantial changes in the annual streamflow parameter being evaluated.

When the double-mass method was selected to analyze changes in streamflow, an assumption was made that breakpoint years would be detected only when the relation between streamflow and precipitation measurably changed. Even though this assumption would only highlight those trends that are not related to changes in climate, this assumption was not always appropriate. Preliminary observations indicated that some upward trends in cumulative annual streamflow may be detected in the double-mass analysis at the start of the wet period. The relation between precipitation and runoff is not necessarily linear. A nonlinear relation between cumulative annual streamflow and cumulative annual precipitation may be caused by changes in the duration and frequency of precipitation during wetter periods compared to drier periods or by increases in base flow from recharge as a result of a series of years with above-normal precipitation. This nonlinearity of the relation between precipitation and streamflow may result in statistically significant breakpoints. These changes in precipitation would not always be apparent when plotting annual precipitation. Therefore, if the breakpoint years showed an increase in base flow, runoff, or total flow starting in the early to mid-1980s, which is likely associated with increased precipitation during the wet period, then an assumption was made that the breakpoint was likely associated with changes in climate and not anthropogenic activity; no further statistical analysis was performed for that station. Further analysis of significant trends in annual streamflow adjusted for changes in precipitation would help to evaluate whether trends in streamflow are associated with climate (Esralew and Lewis, 2010).

\section{Kendall's Tau Analysis}

In the previous step of the analysis, suspected breakpoints were determined that might be used to eliminate nonbaseline years and refine the least-altered period. Stations that had breakpoints detected from double-mass analysis assumed to be related to anthropogenic activity (and not because of the wet period) were further analyzed to calculate trends in streamflow during the least-altered period by using a Kendall's tau test.

Kendall's tau test is a nonparametric statistical test that can be used to indicate the likelihood of an upward or downward trend with time. Information about the Kendall's tau test can be found in Sen (1968) and Kendall and Gibbons (1990). This test is effective for identifying trends in streamflow because extreme data points or skewness in the data have a minimal effect on the outcome of the trend analysis (Helsel and Hirsch, 1992). Kendall's tau test also was used to analyze trends in peak flow and mean annual streamflow by Tortorelli and others (2005), the base flow, runoff, and total flow of selected stations in the Beaver/North Canadian Basin (Wahl and Tortorelli, 1997) and the North Fork Red River Basin (Smith and Wahl, 2003), and base flow, total flow, and base-flow index for selected stations throughout Oklahoma with long-term streamflow record (Esralew and Lewis, 2010). Tau is a dimensionless measure of the correlation between the annual streamflow parameter and time (year), in which positive and negative signs indicate the direction of the trend. A trend is considered to be statistically significant if the null hypothesis of no trend in streamflow with time is rejected. The critical probability ( $\mathrm{p}$-value) for rejection of the null hypothesis is set at 0.05 for this report. The trend slope is a measure of the magnitude of the trend and was computed by using Sen slope estimator (Sen, 1968; Helsel and Hirsch, 1992).

The Kendall's tau test was run for annual base flow, annual runoff, and annual total flow for the period of record or the preliminary least-altered period, and for periods before and after suspected breakpoints determined from the doublemass analysis. Periods before and after suspected breakpoints that were identified for further analysis from the double-mass procedure are referred to in this report as "sub-periods". The Kendall's tau test was used to identify additional trends in streamflow remaining during the sub-periods of record to refine the least-altered period. Kendall's tau also was calculated for base-flow index data for all sub-periods.

At least 15 years of streamflow record in the sub-periods tested were required to run the test to minimize the possibility that trends determined from the Kendall's tau test were not because of climate fluctuations. This minimum required period was reduced from 20 years (used for the visual trend analysis), 
because many of the sub-periods identified from the doublemass analysis were less than 20 years.

Trends detected during any sub-period were used to determine if that period of record should be retained for consideration as the least-altered period, whether to reduce the quality rank of the least-altered period, or whether the station does not have a suitable least-altered period. A statistically significant trend detected in streamflow during the preliminary least-altered period (as identified from steps A and B, fig. 2) not related to climate would indicate that an anthropogenic change may have affected streamflow.

The longest period of record prior to a breakpoint year that did not result in a statistically significant trend because of the Kendall's tau test was selected as a potential least-altered period for each streamflow parameter. Then the shortest potential least-altered period for all streamflow parameters was selected as the final least-altered period. For example, if the longest period of record prior to a breakpoint year that did not result in a statistically significant trend was 1939-1969 for base-flow index and 1939-1965 for base flow, then 19391965, the shorter of the two periods, was selected as the final least-altered period.

Quality ranks were adjusted only if a lesser degree of regulation or other anthropogenic activity (determined from steps A and B of phase 1) during a new shortened least-altered period was determined from this analysis. For example, if a station with a period of record from 1945-2007 was affected by minor wastewater effluent since 1985 that resulted in a quality ranking of "fair", but the new least-altered period determined from this phase was 1945-1982, then the quality ranking would be adjusted to "excellent".

The statistical procedures described were used to eliminate nonbaseline years from the preliminary least-altered period. However, because changes in annual streamflow parameters only represent selected elements of the streamflow regime, a substantially altered period of record may be overlooked by the trend analysis procedures used in this report if anthropogenic activities do not have a visible effect on annual streamflow parameters. For example, some anthropogenic activities such as in-stream diversions or increases in impervious surface may affect the timing or rate of streamflow change, which may not necessarily change the total annual streamflow volume. Because of these limitations, the number of years in the least-altered period of record determined from previous steps were not increased if no statistical changes could be detected by using the methods described. This conservative assumption was used to decrease the likelihood that a substantially altered period of record would be designated as a baseline period.

Several previous publications used similar procedures to assess trends in base flow and total flow. Wahl and Tortorelli (1997) performed a Kendall's tau trend analysis for selected stations in the Beaver-North Canadian River Basin upstream from Canton Lake, and Smith and Wahl (2003) performed a Kendall's tau trend analysis for selected stations in the North Fork Red River Basin. The degree of alteration because of irrigation activities for stations in those basins was determined in both studies. Trend analysis was still performed for these stations in this report because the years of analysis were different than those years used in both studies.

\section{Determination of Optimum Minimum Period of Record to Represent Climate Variability}

An analysis was performed to determine the minimum number of years of precipitation record needed to accurately represent climate variability during 1925-2007. Durations of 5 to 35 years were evaluated for each of the 20 climate divisions that contained stations selected for analysis (fig. 3).

The period 1925-2007 was divided into overlapping moving sub-periods of 5-, 10-, 15-, 20-, 25- and 35-year periods for each climate division. For example, for 10-year periods, the period 1925-2007 was broken up into periods of 1925-1934, 1926-1935, 1927-1936 and so on. The distribution of annual precipitation was compared for each consecutive overlapping 5-year period to the period 1925-2007 by using a Wilcoxon rank-sum test (Wilcoxon, 1945), for each climate division. The test was repeated for the remaining 10-, 15-, 20-, 25-, and 35-year periods.

The null hypothesis specified no difference in the distribution of annual precipitation of the sub-period and the period 1925-2007. A p-value was calculated from the Wilcoxon rank-sum test. The results of this test indicate the probability that a difference exists in the distribution of annual precipitation between the two periods, with the critical p-value set at less than or equal to 0.05 . The optimum minimum period of record for each climate division was defined as the shortest sub-period for which the null hypothesis was not rejected for any of the overlapping sub-periods.

Annual rainfall is dominated by relatively consistent alternating periods of wet and dry that typically last 5 to 10 years, but from the early 1980s to around the year 2000, Oklahoma experienced an unprecedented wet period (Garbrecht and Schneider 2007; Oklahoma Water Resources Board, 2007). Recent and historical data indicate that hydrologic droughts in Oklahoma occurred in water years 1929-1941, 1952-1956, 1961-1972, 1976-1981, and most recently 2006 (Tortorelli and others, 2005; Oklahoma Water Resources Board, 2007). In addition, characteristics of typical climate variability including the wet period may be different depending on climate division (Garbrecht and Schneider, 2007).

The optimum minimum period of record was defined separately for sub-periods starting or mostly ongoing in the wet period, and sub-periods starting in the historically normal climate period (prior to 1980). This procedure was used to reflect the likelihood that the period from the early 1980s to the year 2000 was an uncharacteristically wet period when compared to earlier years. Statistical rejections for 5- and 10-year subperiods were tallied separately for sub-periods starting in 1925 through 1980, and sub-periods starting in 1981 through 2007. The cut-off year for defining the wet period started in 1970 for 
the 15-, 20-, and 25-year sub-periods. A wet-period analysis was not performed separately for the 35 -year periods.

The optimum minimum number of years for a baseline period was identified for each station by comparing the leastaltered period to the minimum number of years determined for the climate division in which the station was located. Streamflow during least-altered periods of record with 50 percent or more of the years after 1980 were considered to be substantially affected by the wet period. The optimum minimum number of years for a baseline period determined for the wet period was applied to stations in which the least-altered period met this criteria. The quality ranking was lowered by one level (for example a "fair" baseline period would be reduced to a "poor" baseline period) for stations that had less than the optimum minimum number of years of streamflow record for a baseline period. If the least-altered period was already "poor", the quality ranking was not changed.

The Wilcoxon rank-sum test also was run for annual precipitation for the least-altered period for each station compared to a long-term period, 1925-2007, for the same climate division. This procedure was used to determine if the least-altered period determined from the previous steps was adequate enough in length and happened during an appropriate time period to be representative of annual climate variability.

If the p-value was at or below the critical value of 0.05 , the null hypothesis of a representative period of record was rejected and the station was considered not to have a suitable baseline period for use in modeling applications. If the p-value was at or below a critical value of 0.1 , the quality ranking for the baseline period was reduced to "poor". Stations that were already previously ranked "poor" were not removed from consideration.

\section{Determination of the Baseline Period of Record}

\section{Least-Altered Period of Record}

One hundred and seventy-one stations were initially considered in the first step of the least-altered period selection process. Table 1 (back of report) lists the known anthropogenic alteration determined from historical information. The table also lists the preliminary quality ranking for the station, which was assigned by using professional judgment, on the basis of the historical information pertaining to human alteration determined for each station. Fifty-five stations were eliminated during this step of the analysis from further consideration in the baseline period analysis because of substantial alteration. If a station was eliminated from consideration, the baseline quality rank was marked "no baseline period" (table 1).

One hundred and sixteen stations that had 10 years of least-altered streamflow record as determined from the first step of the process to determine the least-altered period of record (phase 1, step A, fig. 2) were considered in the second step of the process (phase 1, step B, fig. 2) and are listed in table 2 (back of report). One station, Gaines Creek near Krebs (07232000) with a preliminary quality rank of "excellent" from the previous step, could not be analyzed during the second step because the station was inundated by Lake Eufala and digital drainage information was unavailable (accurate delineations could not be performed). An assumption was made that regulation of streamflow at this station prior to the completion of Lake Eufala was negligible. The table lists the year that 1, 5,10 , and 20 percent regulation by dams were reached for the station during the full period of record and lists the quality rank adjustment that was assigned for the degree of regulation. The preliminary baseline period for 20 stations was reduced and the quality ranking for 73 stations was changed because of the second step of the least-altered period of record analysis (phase 1, step B, fig. 2). The quality ranking for two stations were changed to "no baseline period". The quality ranking for Illinois River at Savoy (07194800), in which about 19 percent of the drainage area was affected by regulation for the period of record, was changed to "no baseline period." The quality ranking for Salt Fork Red River near Elmer (07301110) was changed from "poor" to "no baseline period" because streamflow is likely affected by substantial anthropogenic activity. More than 15 percent of the drainage basin was affected by regulation for the period of record and historical station notes indicated that streamflow was affected by irrigation returns.

Of 114 stations that had a preliminary least-altered period from the second step of the least-altered period analysis (phase 1, step B, fig. 2), 74 stations with 20 or more years of streamflow record prior to the start of substantial regulation or known irrigation (Wahl and Tortorelli, 1997) were analyzed for visual trends in annual base flow, runoff, total flow, and base-flow index (table 3, back of report) as part of the third step of the process (phase 1, step C1, fig. 2). Only data from the years prior to substantial regulation or irrigation were analyzed. Visual inspection revealed that 31 stations had detectable and directional trends in some or all four streamflow parameters during the period of streamflow record prior to substantial regulation. Of those stations, the upward trends in some or all annual streamflow parameters or upward or downward trends in base-flow index at 22 stations were likely associated with the start of the wet period in the early 1980s and an assumption was made that the visual trends were not because of anthropogenic activities such as diversions, withdrawals, regulation, or effluent at these stations. Visual trends were detected during the analysis period for 12 stations for some or all streamflow parameters that were assumed to be unassociated with the wet period. A substantial gap in the least-altered period was identified for Salt Fork Arkansas River near Alva (07148400) (29 years). Double-mass and Kendall's tau tests could not be used to analyze the full dataset because of the streamflow record gap. For this station, base flow was generally higher and runoff was generally lower for the earlier period 1939-1951 than the later period, which indicates that the cause of the trend occurred from 1951-1979; therefore, 
1939-1951 was assumed to be the least-altered period without further analysis.

Analysis of covariance of double-mass curves were performed for 11 stations identified for analysis from the previous step (phase 1, step C2, fig. 2). Table 4 (back of report) shows the results of the double-mass analysis, including statistically significant breakpoint years in which the analysis of covariance and visual interpretation of the results indicated a substantial change in the rate of change of the annual flow parameter relative to precipitation. For each station, the likelihood that the breakpoint year or years associated with the start of the wet period was determined (table 4). Of 11 stations in which the double-mass test was run, 9 stations were selected for further analysis by using the Kendall's tau test (phase 1, step C3, fig. 2).

Results are listed in table 5 (back of report) for the Kendall's tau test for stations in which the test was performed and changes to the least-altered period resulting from this analysis. The quality ranking for Clear Creek near Elmwood (07234100) was changed from "poor" to "no baseline period" because significant downward trends in total flow and runoff were detected during the full period of record, 1966-1993, and the period before the breakpoint identified from doublemass analysis, 1974, was less than 10 years of streamflow record. Significant trends in base-flow index, total flow, or runoff were not detected for the period 1975-1993. This result supported the observation that a substantial change to the streamflow regime happened in mid-1970s. A similar result also was observed by Wahl and Tortorelli (1997), who noted that regional irrigation activities in the Beaver/North Canadian River Basin (which contains this drainage basin) substantially affect streamflow. The least-altered period and quality ranking also were adjusted for Medicine Lodge River near Kiowa, Kansas, (07149000). The end of the least-altered period, 1969, was changed to a year prior to when 5 percent, but after when 1 percent, of the drainage basin was upstream from dams (1968), and resulted in a change in the quality ranking from "fair" to "good".

\section{Optimum Minimum Period of Record}

The optimum minimum period of record for each climate division is listed in table 6 . Results of the analysis indicated that optimum periods of record for climate divisions ranged from 10 to 35 years for the normal period (prior to 1980) and after the start of the wet period (1980). In general, during the period prior to the start of the wet period, stations in northeast Oklahoma and southwest Missouri, and stations in southwest Oklahoma, require a longer streamflow record than stations in other areas to include a climate that is representative of the longer period (fig. 6). In contrast, stations in central and southern Oklahoma and southwest Arkansas need more streamflow record after the start of the wet period compared with surrounding climate divisions. Stations located in many of the climate divisions had optimum minimum periods of record of 15 or more years for periods of record that mostly occurred prior to the wet period, and 20 or more years of streamflow record for periods of record mostly occurring during the later wet period. Twenty-seven stations had quality rankings that were changed because of this phase of the analysis (phase 2, step A, fig. 2). Final quality rankings for each station because of this analysis are listed in table 7 (back of report). Stations that did not have a baseline period because of previous analyses are not listed in table 7.

Annual precipitation during the least-altered period for 113 stations was compared to the period 1925-2007 to determine if the least-altered period happened during an appropriate time period to be representative of a annual climate variability (phase 2, step B, fig. 2). The least-altered periods for two stations, Sweetwater Creek near Sweetwater (07301420) and Salt Creek near Okeene (07158400), were removed from consideration as a baseline period because the critical $p$-value for annual precipitation for the least-altered period was less than or equal to 0.05 from the Wilcoxon rank-sum test. Four other stations had $\mathrm{p}$-values that were greater than 0.05 but were less than 0.1. Stahl Creek near Miller, Missouri, (07185500) and Spring River at LaRussell, Missouri, (07185700) had a baseline period initially ranked "excellent" from previous analysis, but were changed to "poor". Washita River near Clinton, Oklahoma, (07325000) and Bird Creek at Avant, Oklahoma, (07176500) already had a preliminary least-altered period that was ranked "poor", so the quality ranking was not changed for the baseline period because of this analysis.

\section{Final Baseline Period}

A final baseline period and quality ranking were determined for 111 stations (65 percent of stations analyzed). Of 171 stations analyzed for a baseline period, a suitable baseline period for modeling applications could not be identified for 60 stations (35 percent of stations analyzed). A baseline period could not be identified for 58 stations because of substantial anthropogenic alteration of the stream or drainage basin and for 2 stations because the least-altered period of record was not representative of annual climate variability. Table 7 (back of report) lists the baseline period determined for each station (if the station had a baseline period) and the associated quality ranking of the baseline period (fig. 7). Stations that do not have a baseline period are not listed in table 7 . In figure 6, a quality ranking of "no baseline period" was assigned to stations from table 1 (back of report) that did not have a baseline period.

Baseline periods were rated as "excellent" for 22 stations, "good" for 42 stations, "fair" for 24 stations, and "poor" for 23 stations. Out of 22 stations with baseline periods that were rated "excellent", 12 stations were in southeastern Oklahoma (defined as tributaries that drain to the Red River downstream from Lake Texoma, fig. 7). No clear spatial patterns in the location of stations with baseline periods rated "good", "fair" and "poor" were apparent. 
A

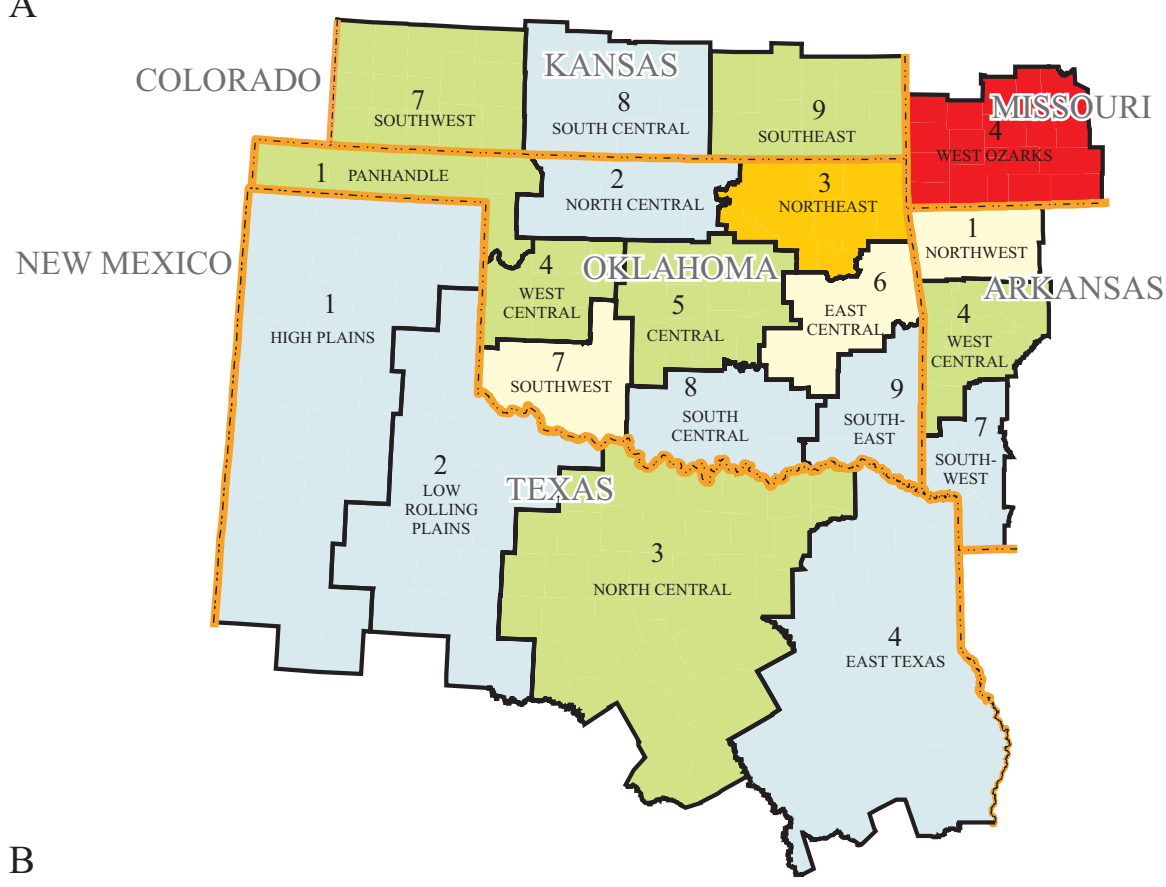

\section{EXPLANATION}

Climate Division boundaries and optimum minimum number of years of streamflow record for streamflowgaging stations in climate division
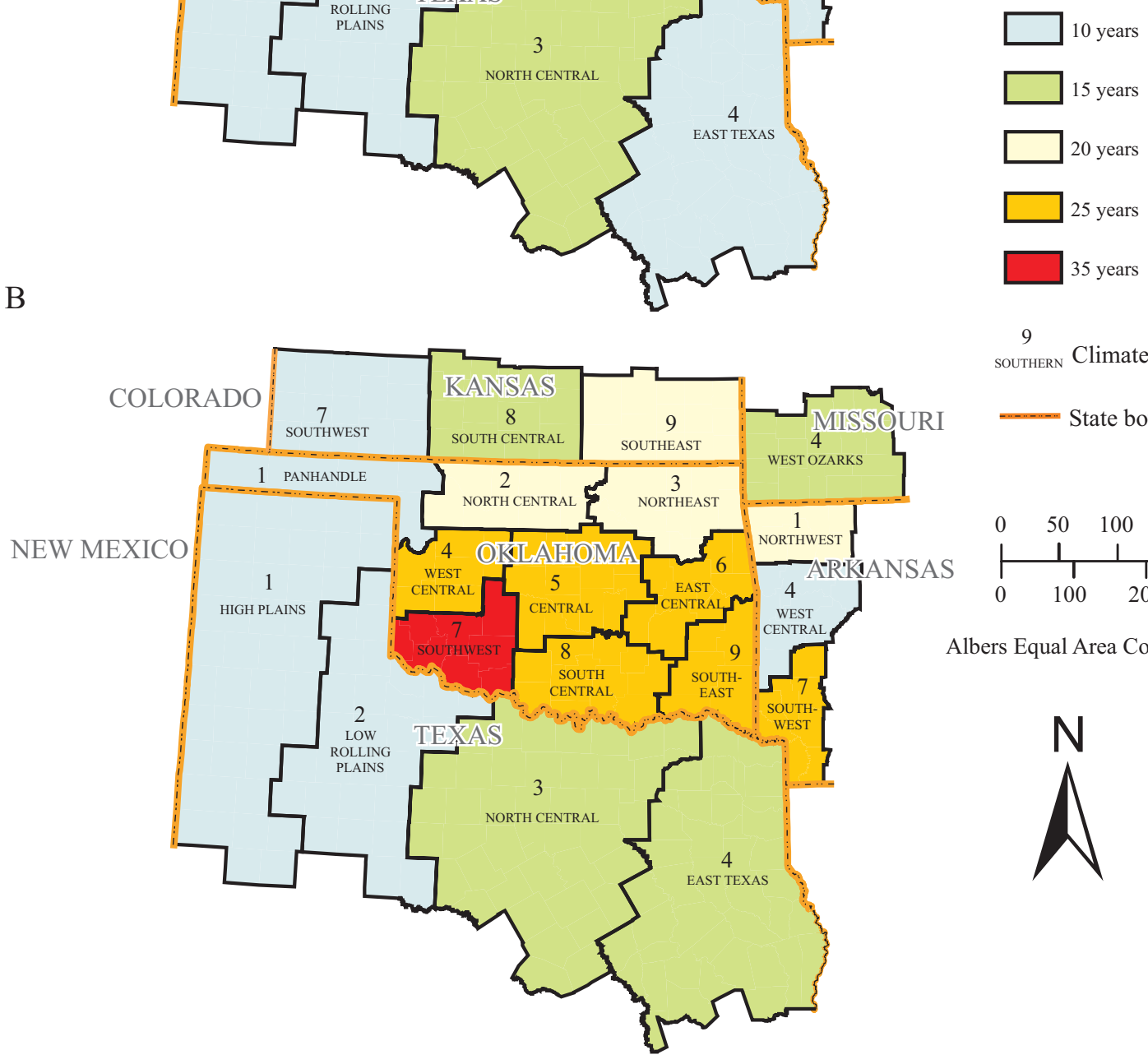

$\stackrel{9}{\text { soUTHERN Climate Division number and name }}$

State boundary

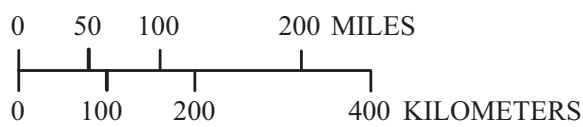

Albers Equal Area Conic Projection

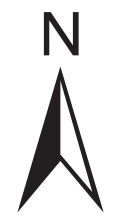

Figure 6. Climate divisions used in the process to determine a baseline period of record for selected streamflow-gaging stations in and near Oklahoma, and the optimum minimum number of years of streamflow record needed for the baseline period for streamflow-gaging stations in those climate divisions, defined separately for gages located in each climate division for (A) periods of record where more than 50 percent of years occurred prior to 1980, the historically normal period, and (B) periods of record where more than 50 percent of years occurred after 1980s, the historically wet period. 


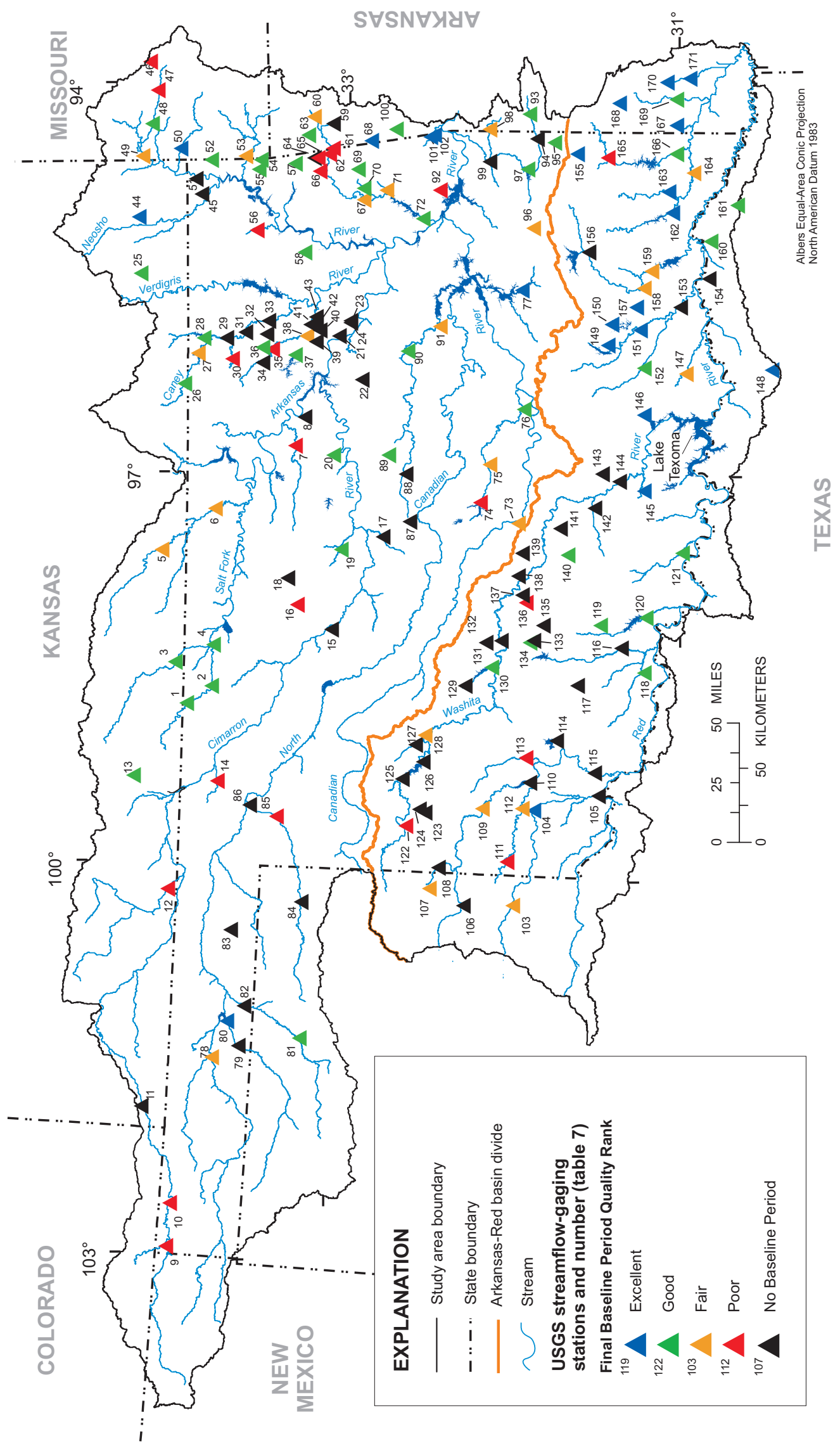

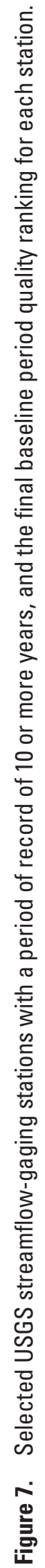


Baseline periods represented a wide range of years, starting with 1924 and included baseline periods that extended through 2007. Baseline periods ranged from 10 years to 84 years, with an average of 26 years. Of 111 stations with a baseline period, 83 percent of stations had a baseline period that was less than 40 years. Of the stations with a baseline period, more than 80 percent of stations had baseline periods that included one or all years between 1949 and 1964. Twentyseven percent of stations had baseline periods that included any of the years between 1924 and 1939. Thirty-five percent of stations included years after 1981, indicating that most stations in this report do not have baseline periods that extend through the wet period. Even though the years 1940-1980 were better represented by baseline periods than years before or after this period, a concurrent baseline period for all stations could not be established. No single year was indicated when more than 60 percent of stations had baseline periods that contained that year. This inconsistency may have been the result of increases in regulation after the 1960s, especially with large-scale construction of Natural Resources Conservation Service (formerly Soil Conservation Service) dams (Tortorelli, 1997 and 2002; Lewis and Esralew, 2009; Smith and Esralew, 2009), and short-term maintenance of unregulated stations with drainage areas less than 2,500 square miles.

Anthropogenic activity that may affect streamflow during the baseline period was noted for 44 stations. The most commonly noted anthropogenic activity for stations that had baseline periods was minor regulation. Twenty-two stations had baseline periods that were affected by minor regulation as indicated by the number of dams in the drainage basin (including two stations that were affected by backwater from nearby regulation) 12 stations had baseline periods that were affected by diversion or withdrawal, 12 stations had baseline periods that were affected by irrigation activity, and 3 stations were affected by effluent. More than one type of anthropogenic activity was noted for eight stations.

\section{Summary}

Use of historical streamflow data from a least-altered period can enhance water resources planning by using these data in calibration of various watershed modeling applications. This information is especially useful for watershed models that are used to characterize least-altered streamflow and predict the effects of proposed streamflow alteration. To address this need, the U.S. Geological Survey, in cooperation with Oklahoma State University and the Oklahoma Water Resources Board, determined baseline periods of record for selected streamflow-gaging stations that can be used as a calibration dataset for modeling applications. The baseline period was defined as a period that is least-altered by anthropogenic activity and has sufficient streamflow record length to represent the extreme wet and dry periods included in typical annual climate variability. Streamflow data from 171 stations in and near Oklahoma with a minimum of 10 complete water years of daily streamflow record through water year 2007 and drainage areas that were less than 2,500 square miles were considered for use in the baseline-period analysis.

In the first step of the process to determine the leastaltered period, historical basin information was used to identify anthropogenic activities in each drainage-basin that may affect streamflow. Station information was evaluated by using previous publications, historical station record notes, and information gathered from oral and written communication with U.S. Geological Survey hydrographers familiar with selected stations. This information was used to eliminate streamflow record from selected stations to identify a preliminary least-altered period. Quality rankings were assigned for each preliminary least-altered period on the basis of professional judgment of the suspected degree of alteration as determined from this step.

The second step was to determine for the least altered period, the stations that had substantial effects from upstream regulation by documenting the location of dams in the drainage basin. The drainage area upstream from the dams was determined and the percentage of the total drainage area for the station that was affected by dams was calculated. The year that the dams were completed was used to construct a plot of downstream drainage area affected by dams with time. The least-altered period was refined from the previous step by either (a) excluding years in which the percent of the drainage area upstream from dams ranged from 1 percent to 20 percent if at least 10 years of streamflow record remained after the years were excluded, or (b) modification of the quality rank for the period of record on the basis of the percentage of the drainage area affected by dams.

The third step of the determination of the least-altered period was visual analysis of annual hydrographs, and included analysis of covariance of double-mass curves and Kendall's tau analysis to detect statistically significant changes in base flow, runoff, total flow and base-flow index for selected stations.

Annual plots of these parameters for stations were created and visually analyzed to identify changes in streamflow. If the station had 20 years or more of streamflow data available prior to the start of substantial regulation or irrigation, as determined from steps 1 and 2, only those 20 years or more of data were analyzed. If a noticeable change in any of the annual streamflow parameters were detected but were not assumed to be caused by increases in precipitation, then the station was further considered for statistical trend analysis.

Double-mass curves were created to relate annual base flow, annual runoff, and annual total flow to annual precipitation for the climate division for each station selected from the visual hydrograph analysis. Statistical breakpoints identified by the double-mass analysis were visually examined to determine if the breakpoints most likely represented substantial changes in the annual streamflow parameter being evaluated.

A Kendall's tau trend test was run for annual base-flow, annual runoff, and annual total-flow for the the preliminary 
least-altered period determined from previous steps, and for sub-periods before and after suspected breakpoints determined from the double-mass analysis for stations with preliminary least-altered periods and sub-periods of at least 15 years of streamflow record. The test was used to identify additional trends in streamflow remaining during the sub-periods of record for a refined least-altered period. Trends detected during any sub-period were used to (1) determine if that streamflow record should be retained for consideration as the least-altered period, (2) reduce the quality rank of the leastaltered period, or (3) determine that the stream does not have a least-altered period suitable for a baseline period.

An optimum minimum period of record was determined for each of the least-altered periods for each station to ensure that the least-altered period had a sufficient streamflow record length to provide a representative sample of climate variability. An optimum minimum period of 10 years or more were evaluated by analyzing the variability of annual precipitation for selected 5-, 10-, 15-, 25-, and 35-year periods for each of 20 climate divisions that contained stations used in the baseline period analysis. The distribution of annual precipitation was compared for each consecutive overlapping 5-year period to the period 1925-2007 by using a Wilcoxon rank-sum test. The least-altered period of record for stations also was compared to the period 1925-2007 by using a Wilcoxon ranksum test. The results from the test were used to determine how many years of annual precipitation were needed for the distribution of annual precipitation for the selected least-altered period to be statistically similar to the distribution of annual precipitation for a long-term period (1925-2007).

Of 171 stations analyzed for a baseline period, a final baseline period and quality ranking were determined for 111 stations (65 percent of stations analyzed), and a suitable baseline period for modeling applications could not be identified for 60 stations ( 35 percent of stations analyzed). A baseline period could not be identified for 58 stations because of substantial anthropogenic alteration of the stream or drainage basin and for 2 stations because the least-altered period of record was not representative of annual climate variability. The baseline period for each station was rated"excellent", "good", "fair", "poor", or "no baseline period" on the basis of a qualitative evaluation of the approximate degree of basin alteration for the least-altered period, and whether or not the least-altered period was long enough to be representative of long-term climate variability. Baseline periods were rated as "excellent" for 22 stations, "good" for 42 stations, "fair" for 24 stations, and "poor" for 23 stations.

Eighty-three percent of stations with a baseline period had a baseline period of less than 40 years. Of 111 stations with a baseline period, more than 80 percent of stations had baseline periods that included the years 1949-1964. Thirtyfive percent of stations included years after 1981, indicating most stations analyzed in this report do not have baseline periods that extend through the wet period. The most commonly noted anthropogenic activity for stations that had baseline periods was minor regulation.

\section{References}

Bergman, D. L., and Huntzinger, T.L., 1981, Rainfall-runoff hydrograph and basin characteristics data for small streams in Oklahoma: U.S. Geological Survey Open-File Report 81-824, $320 \mathrm{p}$.

Donigian, A.S., Jr., Imhoff, J.C., Bicknell, Brian, Kittle, J.L., Jr., 1984, Application guide for Hydrological Simulation Program-Fortran (HSPF): U.S. Environmental Protection Agency, Environmental Research Laboratory, Athens, Ga., EPA-600/3-84-065, 177 p.

Environmental Systems Research Institute, Inc. (ESRI), 2007, ArcInfo version 9.2, available online at http://webhelp.esri. com/arcgisdesktop/9.2. (Accessed July 1, 2008.)

Esralew, R.A., and Baker, R.J., 2008, Determination of baseline periods of record for selected streamflow-gaging stations in New Jersey for determining ecologically relevant hydrologic indices (ERHI): U.S. Geological Survey Scientific Investigations Report SIR 2008-5077, 70 p.

Esralew, R.A., and Lewis, J.M., 2010, Trends in base flow, total flow, and base-flow index of selected streams in and near Oklahoma: U.S. Geological Survey Scientific Investigations Report SIR 2010-5104, 143 p.

Esralew, R.A., and Smith, S.J., 2009, Methods for estimating flow-duration and annual mean-flow statistics for ungaged streams in Oklahoma: U.S. Geological Survey Scientific Investigations Report 2009-5267, 131 p.

Fitzpatrick, F.A., Knox, J.C., and Whitman, H.E., 1999, Effects of historical land-cover changes on flooding and sedimentation, North Fish Creek, Wisconsin: U.S. Geological Survey Water-Resources Investigations Report 99-4083, $12 \mathrm{p}$.

Friedman, J. H., 1984, A variable span scatterplot smoother: Laboratory for Computational Statistics, Stanford University, Technical Report No. 5.

Garbrecht, Jurgen, and Schneider, Jeanne, 2007, 1895-2005 Annual precipitation, long-term trends, persistent variations, and annual precipitation expectations for Oklahoma Climate Divisions: U.S. Department of Agriculture, Grazinglands Research Laboratory, 47 p., available online at http://ars. usda.gov/Main/docs.htm?docid=11617. (Accessed July 1, 2008.)

Havnø, K., Madsen, M.N., and Dørge, J., 1995, MIKE 11 - A generalized river modelling package, in Vijay P. Singh, ed., Computer models of watershed hydrology: Water Resources Publications, Highlands Ranch, Colo., p. 733-782.

Heimann, D.C., and Tortorelli, R.L., 1988, Statistical summaries of streamflow records in Oklahoma in parts of 
Arkansas, Kansas, Missouri, and Texas through 1984: U.S. Geological Survey Water-Resources Investigations Report 87-4205, 387 p. (Also available online at http://pubs. er.usgs.gov/usgspubs/wri/wri874205.)

Helsel, D.R., and Hirsch, R.M., 1992, Statistical methods in water resources: Elsevier, 522 p. (Also published as U.S. Geological Survey Techniques of Water-Resources Investigations, book 4, chapter A3, 510 p., available online at http://pubs.usgs.gov/twri/twri4a3/.)

Howell, Michael, and Johnson, T.G. 2003, Oklahoma's timber industry-An assessment of timber product output and use, 1999: U.S. Department of Agriculture, Forest Service, Southern Research Station, Resource Bulletin SRS-82, 28 p.

Institute of Hydrology, 1980, Low flow studies: Wallingford, Oxon, United Kingdom, Institute of Hydrology Report No. 3, p. 12-19.

Kendall, Maurice, and Gibbons, J.D., 1990, Rank correlation methods (5th ed.): New York, Oxford University Press, 260 p.

Konrad, C.P., and Booth, D.B., 2002, Hydrologic trends associated with urban development for selected streams in the Puget Sound basin, western Washington: U.S. Geological Survey Water-Resources Investigations Report 02-4040, $40 \mathrm{p}$.

Leavesley, G.H., Lichty, R.W., Troutman, B.M., and Saindon, L.G., 1983, Precipitation-Runoff Modeling SystemUser's Manual: U.S. Geological Survey Water-Resources Investigations Report 83-4238, 207 p.

Lewis, J.M., and Esralew, R.A., 2009, Statistical summaries of streamflow in and near Oklahoma through 2007: U.S. Geological Survey Scientific Investigations Report 2009-5135, $633 \mathrm{p}$.

Long, S.C.A., Reece, B. D., Eames, D.R., 2004. Water resources data Texas, water year 2004, volume 1-Arkansas River basin, Red River basin, Sabine River basin, Neches River basin, and intervening coastal basins: U.S. Geological Survey Water Data Report TX-04-01.

National Oceanic and Atmospheric Administration (NOAA), 2008, National Climatic Data Center Climate Monitoring Reports and Products, available online at http://www.ncdc. noaa.gov/oa/climate/research/monitoring.html. (Accessed July 1, 2008.)

Oklahoma Climatological Survey, 2007, Oklahoma climate data, available online at http://climate.mesonet.org/default. php. (Accessed July 1, 2008.)

Oklahoma Water Resources Board, 2007, Hydrologic drought of water year 2006-A historical Context: Oklahoma Water Resources Board Circular, 4 p.
Preston, S.D., Alexander, R.B., Woodside, M.D., and Hamilton, P.A., 2009, SPARROW MODELING-Enhancing understanding of the Nation's water quality: U.S. Geological Survey Fact Sheet 2009-3019, 6 p.

Schein, Gary, 2008, Stimulation for shale resources plays: Energy Institute Resource Workshop, January 14-15, 2008, Fort Worth, Texas, Texas Christian University.

Searcy, J.K., and Hardison, C.H., [by W.B. Langbein], 1960: Double-mass curves, with a section on Fitting curves to cyclic data: U.S. Geological Survey Water-Supply Paper 1541-B, 66 p.

Sen, P.K., 1968, On a class of aligned rank order tests in two-way layouts: Annals of Mathematical Statistics, v. 39, p. $1,115-1,124$.

Smith, S.J., and Esralew, R.A., 2009, StreamStats in Oklahoma-Drainage-basin characteristics and peak-flow frequency statistics for ungaged Streams: U.S. Geological Survey Scientific Investigations Report 2009-5255, 58 p.

Smith, S.J., and Wahl, K.L., 2003, Changes in streamflow and summary of major-ion chemistry and loads in the North Fork Red River basin upstream from Lake Altus, northwestern Texas and western Oklahoma, 1945-1999: U.S. Geological Survey Water-Resources Investigations Report 03-4086, 36 p. (Also available online at http://pubs.usgs. gov/wri/wri034086/.)

Snedecor, G.W., 1934, Calculation and interpretation of analysis of variance and covariance: Ames, Iowa, Collegiate Press, Inc., 96 p.

Stankowski, S.J., 1972, Population density as an indirect indicator of urban and suburban land-surface modifications, in Geological Survey Research: U.S. Geological Survey Professional Paper 800B, p. 219-224.

Tortorelli, R. L., 1997, Techniques for estimating peakstreamflow frequency for unregulated streams and streams regulated by small floodwater-retarding structures in Oklahoma: U.S. Geological Survey Water-Resources Investigations Report 97-4202, 39 p. (Also available online at http://pubs.usgs.gov/wri/wri974202/.)

Tortorelli, R.L., 2002, Statistical summaries of streamflow in Oklahoma through 1999: U.S. Geological Survey Water-Resources Investigations Report 02-4025, 510 p. (Also available online at http://pubs.usgs.gov/wri/ wri024025/.)

Tortorelli, R.L., 2005, Estimated freshwater withdrawals in Oklahoma: U.S. Geological Survey available online at http://ok.water.usgs.gov/infodata/wateruse.html. (Accessed July 1, 2008.) 
Tortorelli, R.L., 2009, Water use in Oklahoma 1950-2005: U.S. Geological Survey Scientific Investigations Report 2009-5212, 49 p. (Available online at http://pubs.usgs.gov/ sir/2009/5212/.)

Tortorelli, R.L., and Bergman, D.L., 1985, Techniques for estimating flood peak discharges for unregulated streams and streams regulated by small floodwater-retarding structures in Oklahoma: U.S. Geological Survey Water-Resources Investigations Report 84-4358, 85 p.

Tortorelli, R.L., Rasmussen, T.J., and Perry, C.A., 2005, Trends in annual peak flows and mean annual flows of selected streams within and near Oklahoma: U.S. Geological Survey Scientific Investigations Report 2005-5192, 116 p. (Also available online at http://pubs.usgs.gov/ sir/2005/5192/.)

Turton, Don, Fisher, William, Seilheimer, T.S., Esralew, R.A., 2009, An assessment of environmental flows for Oklahoma: Oklahoma Water Resources Research Institute Research Report, available online at http://water.usgs. gov/wrri/08grants/progress/20080K107B.pdf. (Accessed November 2009)

U.S. Army Corps of Engineers, 2008, National inventory of dams: U.S. Army Corps of Engineers digital geodatabase available online at https://nid.usace.army.mil. (Accessed July 1, 2008.)

U.S. Department of Agriculture, 2008, National Agriculture Imagery Program (NAIP): U.S. Department of Agriculture imagery database via the Aerial Photography Field Office, available online at http://www.fsa.usda.gov/FSA/apfoapp? area $=$ home \& subject $=$ prog \& topic $=$ nai. (Accessed July 1 , 2008).
U.S. Geological Survey, 2008, Annual Water Data Reports: U.S. Geological Survey, available online at http://wdr.water. usgs.gov/. (Accessed July 1, 2008.)

U.S. Geological Survey, 2009a, National Streamflow Statistics Program, available only online at http://water.usgs.gov/osw/ programs/nss/index.html. (Accessed April 15, 2009.)

U.S. Geological Survey, 2009b, The National Map Viewer, available only online at http://viewer.nationalmap.gov/ viewer/. (Accessed January 10, 2009.)

Vance, Brian, ed., 2007, Centennial edition of the Oklahoma Water Atlas: Oklahoma Water Resources Board, 190 p.

Wahl, K.L., and Tortorelli, R.L., 1997, Changes in flow in the Beaver-North Canadian River basin upstream from Canton Lake, western Oklahoma: U.S. Geological Survey WaterResources Investigations Report 96-4304, 58 p. (Also available online at http://pubs.usgs.gov/wri/wri964304/.)

Wahl, K.L., and Wahl, T.L., 1995, Determining the flow of Comal Springs at New Braunfels, Texas, in Proceedings of Texas Water '95, August 16-17, 1995, San Antonio, Texas: American Society of Civil Engineers, p. 77-86.

Wigbout M., 1973, Limitations in the use of double-mass curves: Journal of Hydrology, v. 12, no. 2, p. 132-138.

Wilcoxon, Frank, 1945, Individual comparisons by ranking methods: Biometrics Bulletin, v. 1, no. 6, p. 80-83.

Wolock, D.M., 1993, Simulating the variable-source-area concept of streamflow generation with the watershed model TOPMODEL: U.S. Geological Survey Water-Resources Investigations Report WRIR 93-4124, 33 p. 


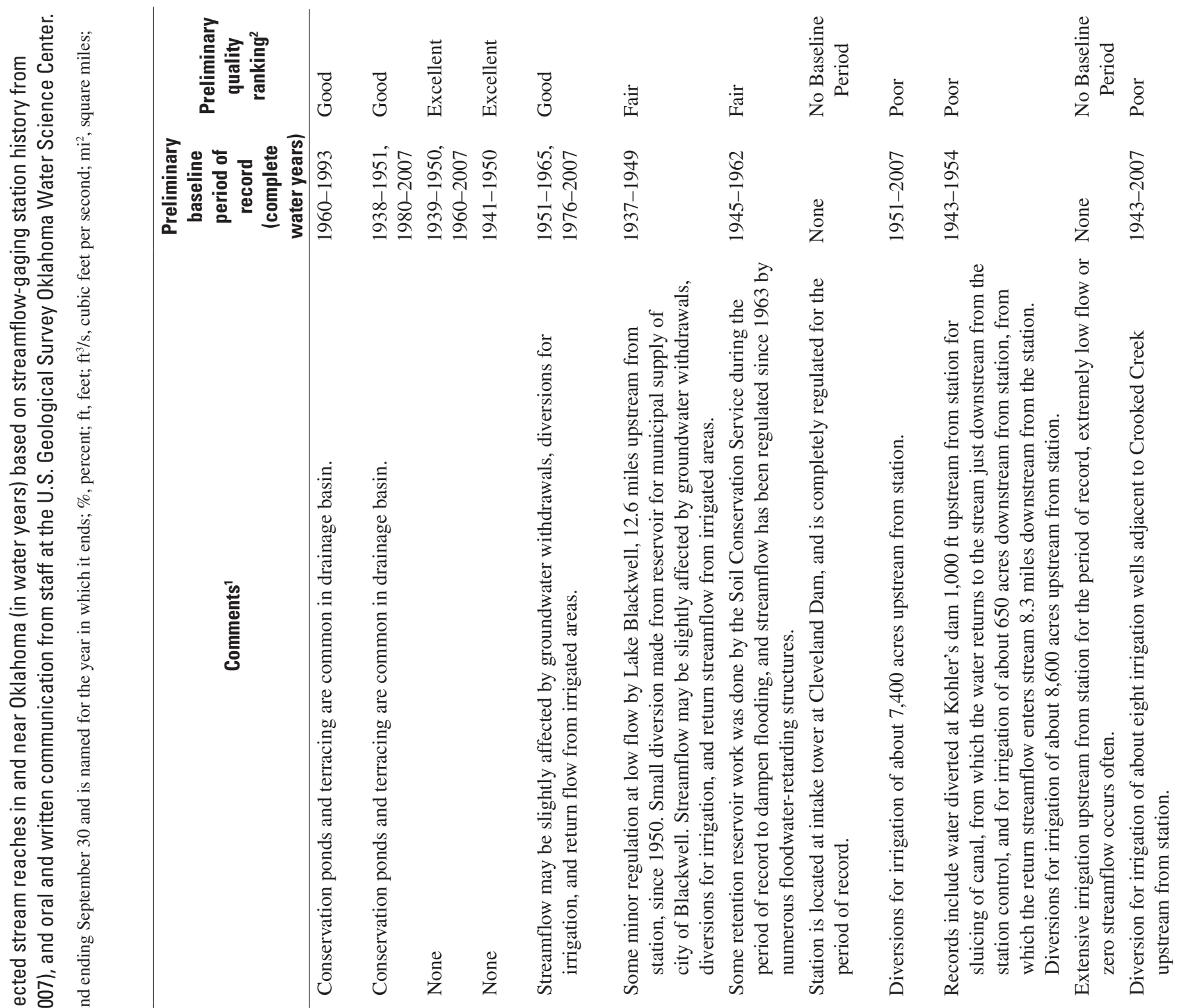

๘

혼

훙응.

离离

赵

즐

.

훈 站

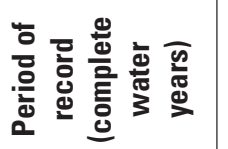

$\frac{1}{2}$

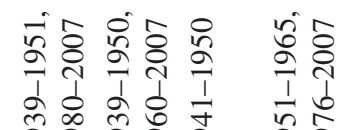

ڤิ)

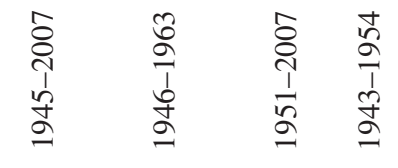

유 हิ

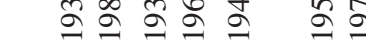

$\frac{1}{2}$

กิ

ᄃ 可 $\cong$

.음 음

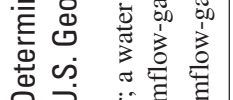

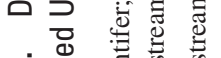

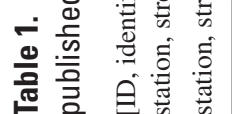

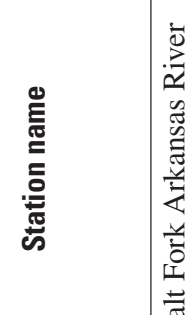

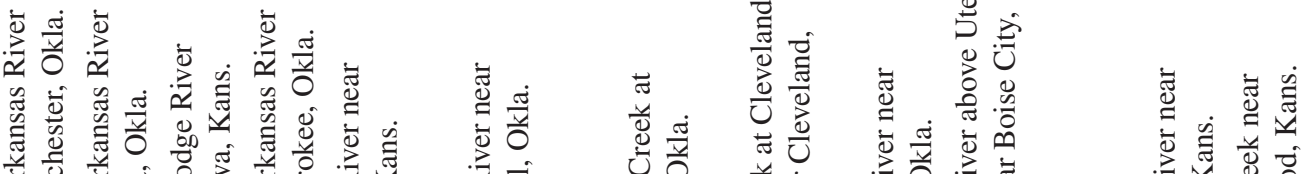

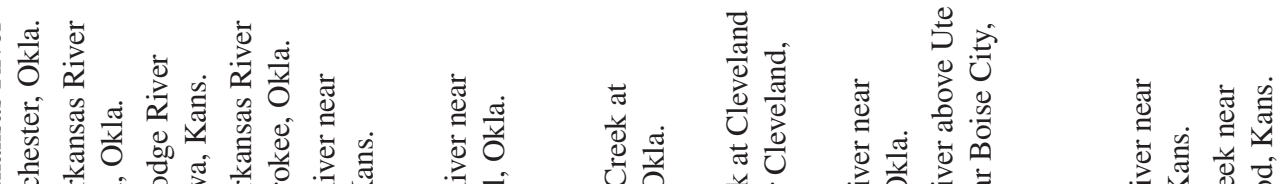

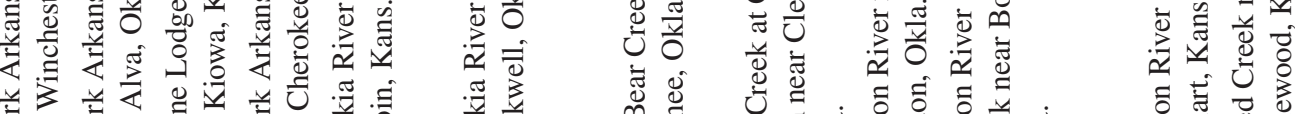

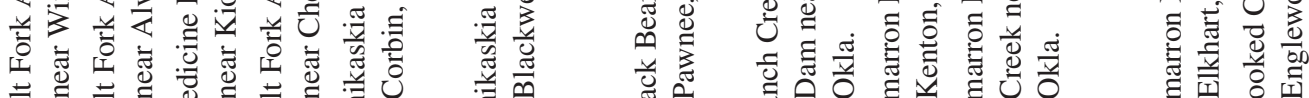

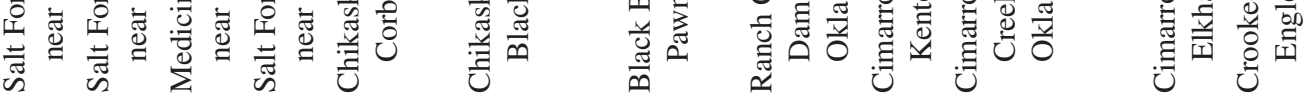

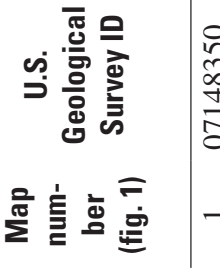

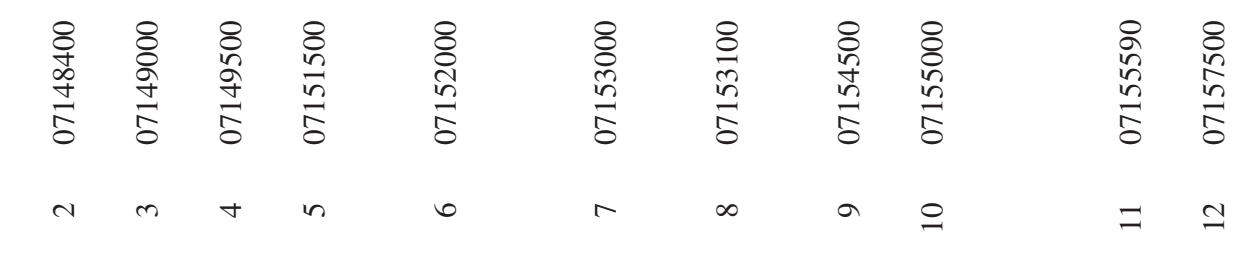




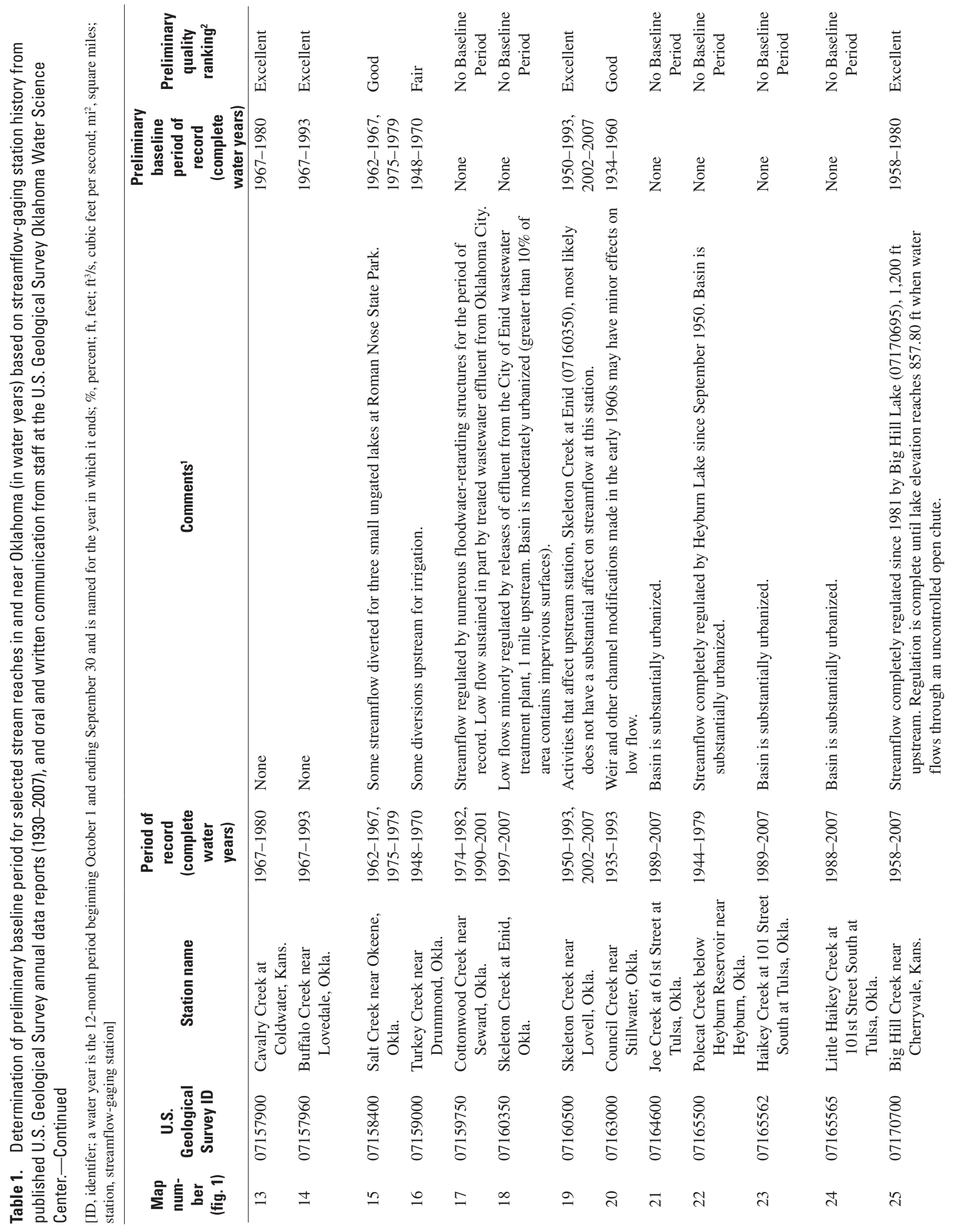




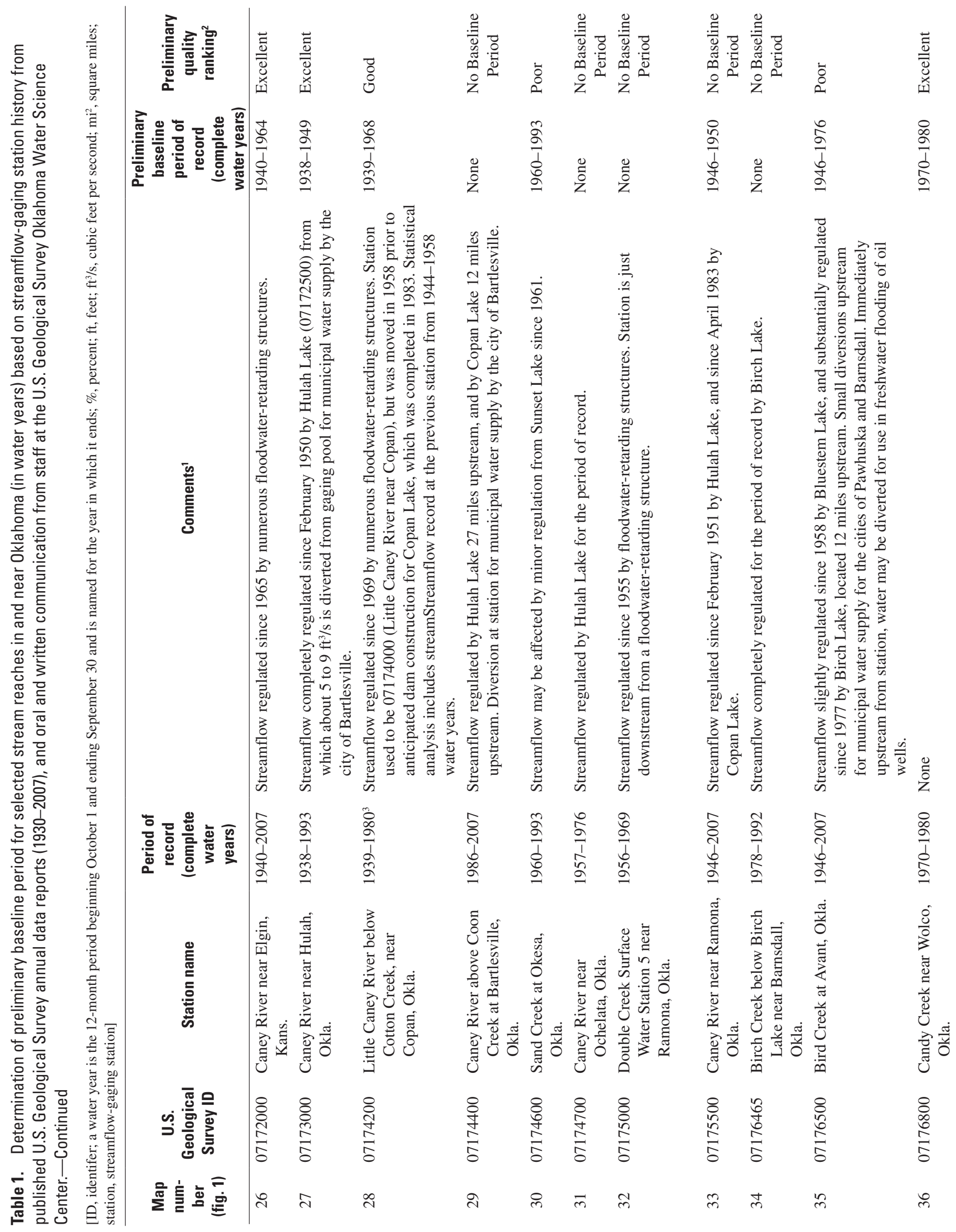




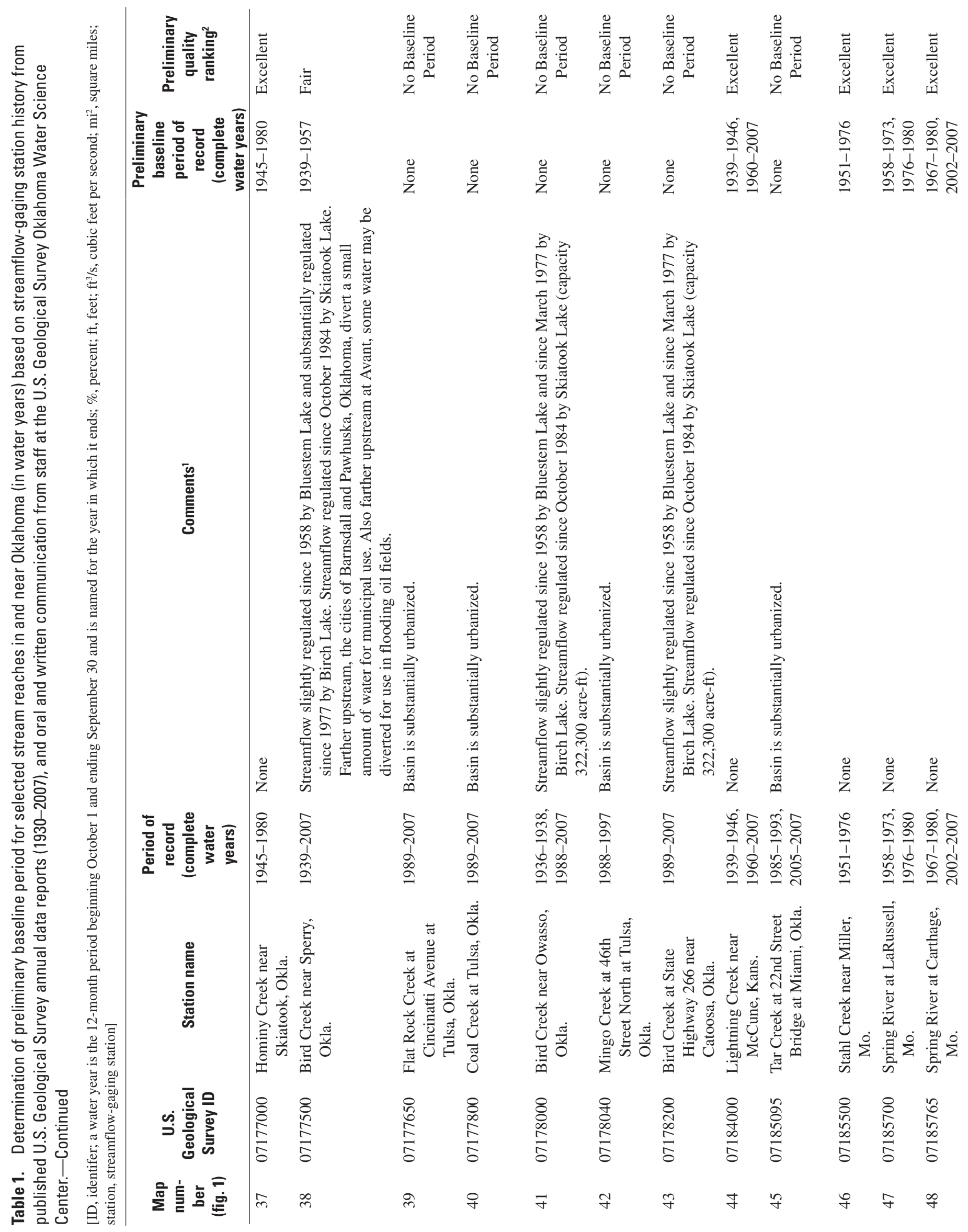




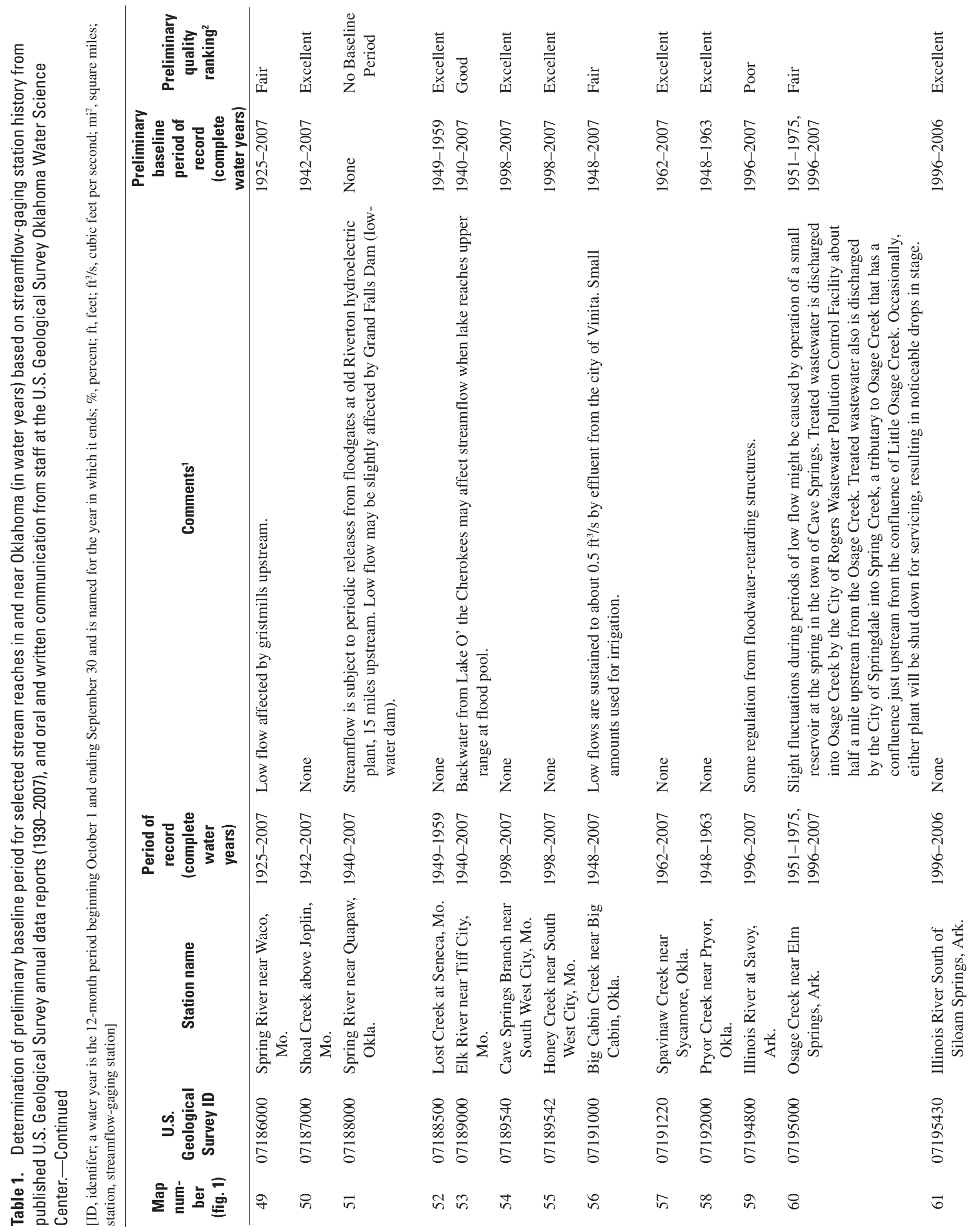




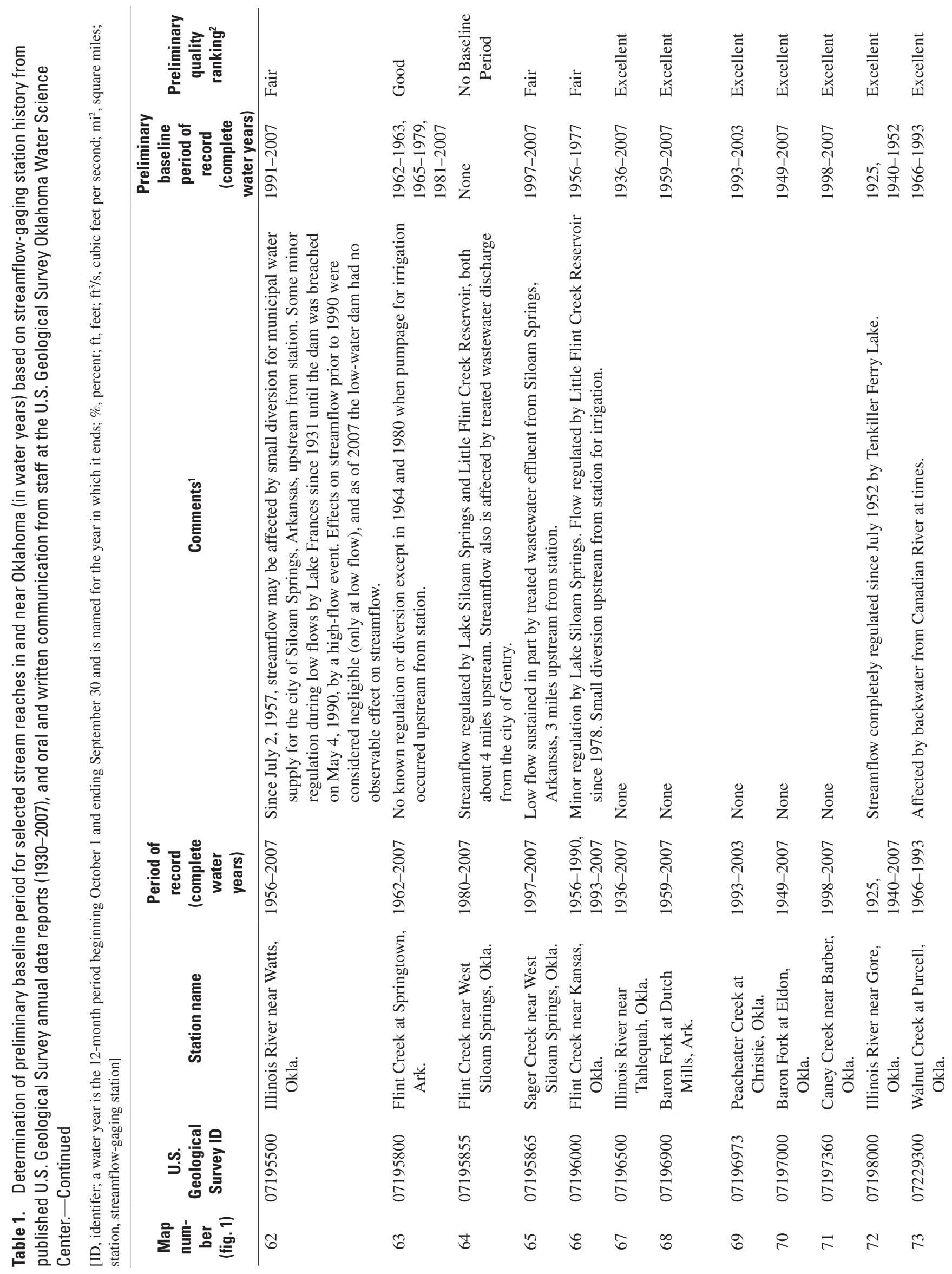




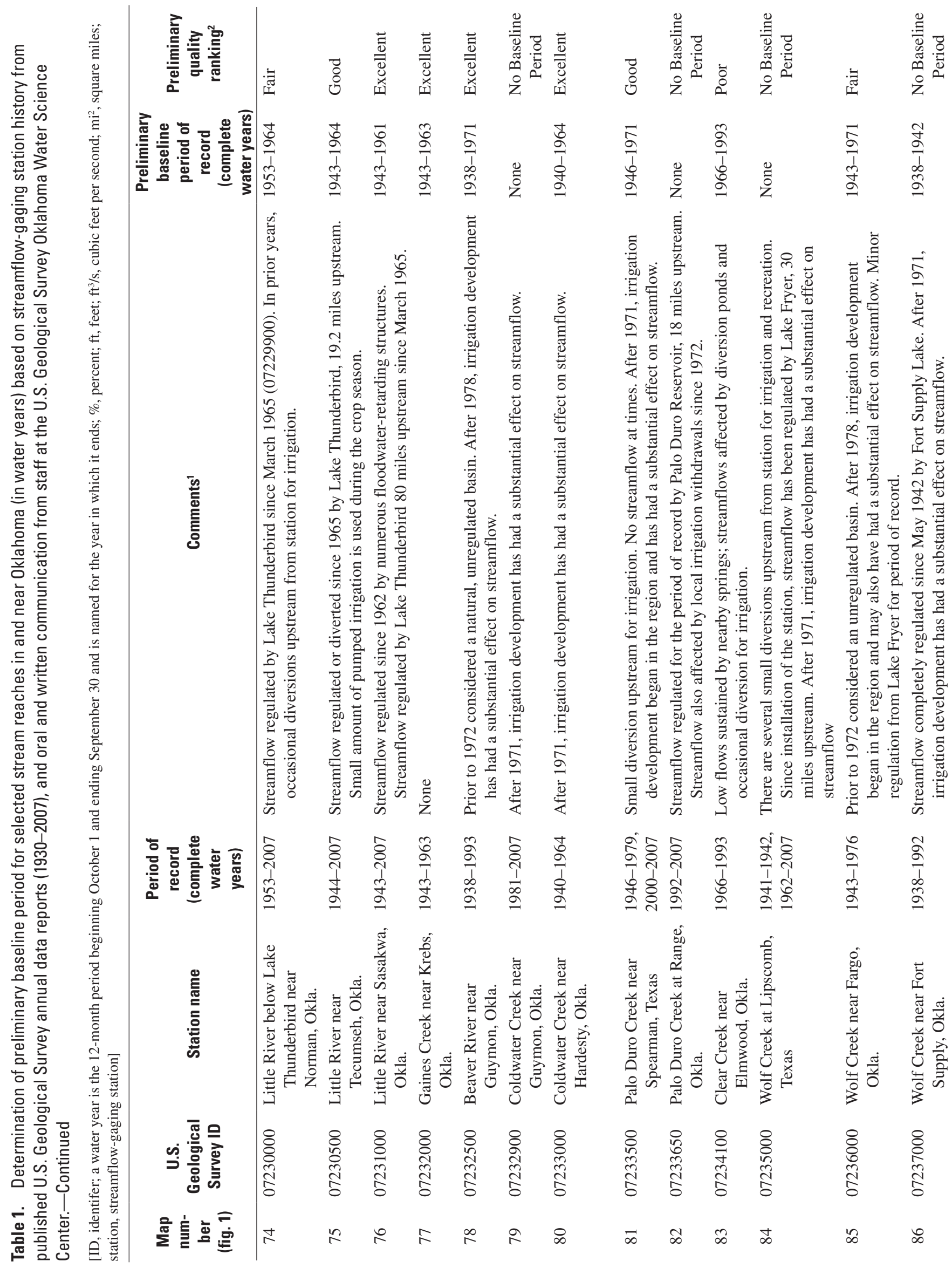




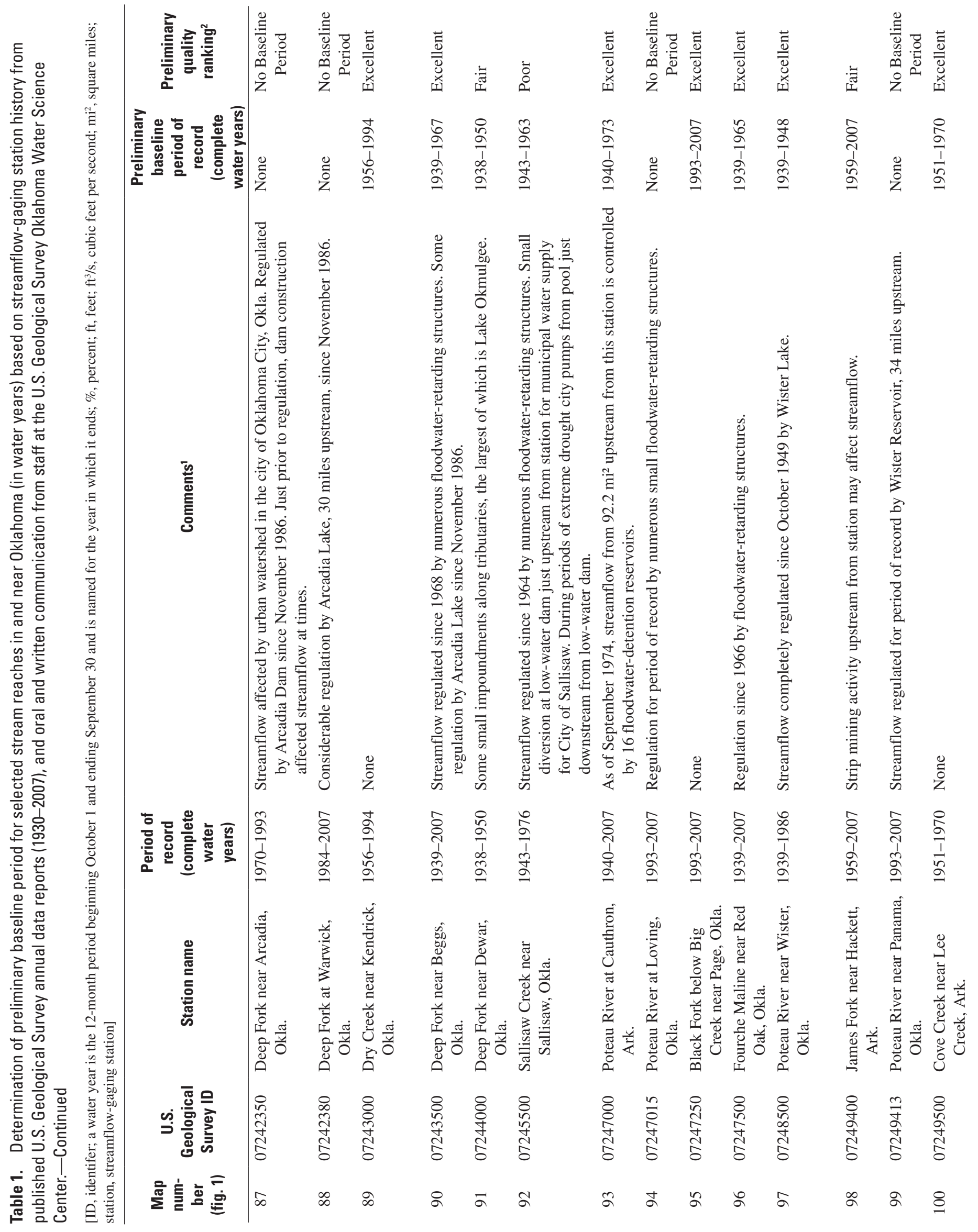




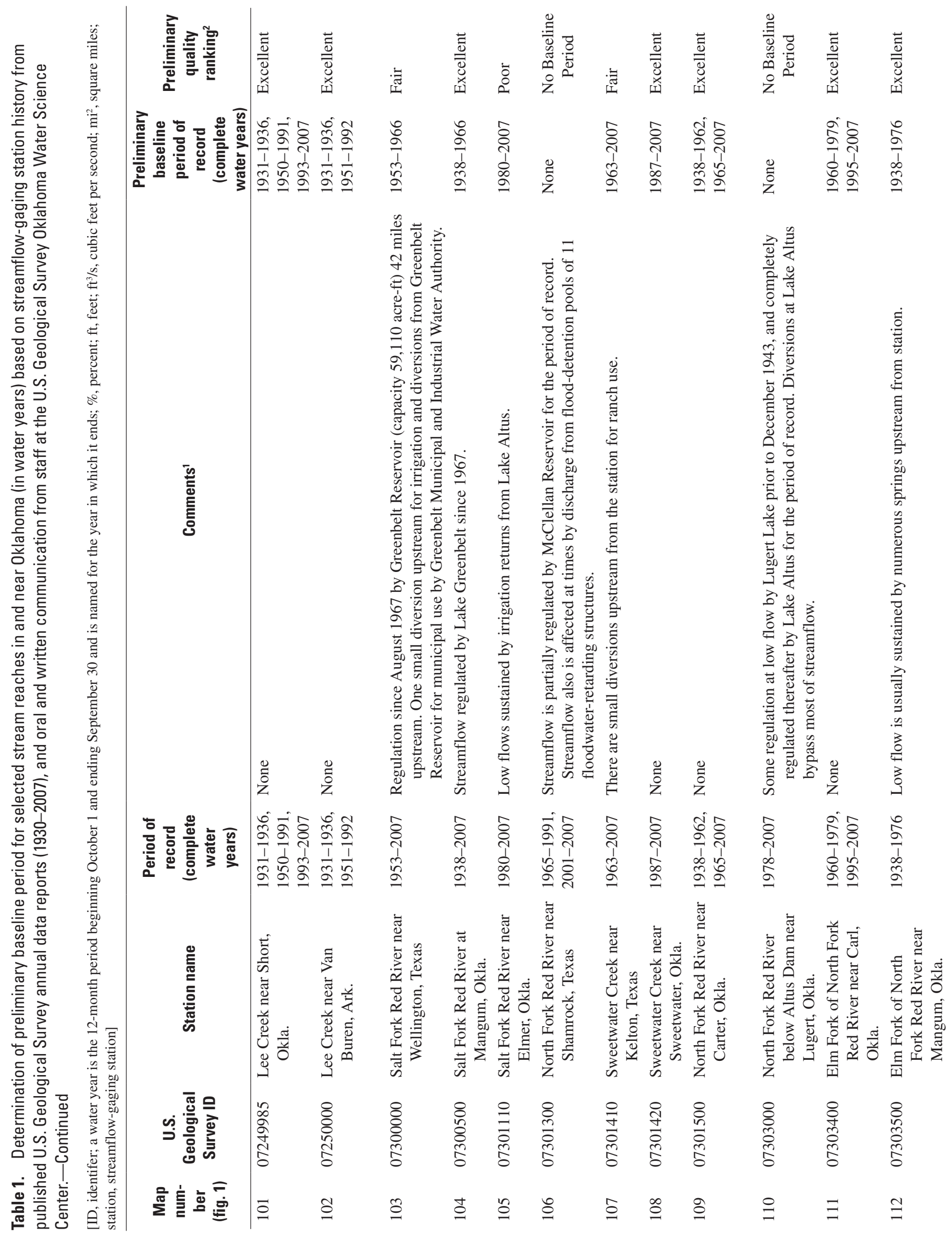




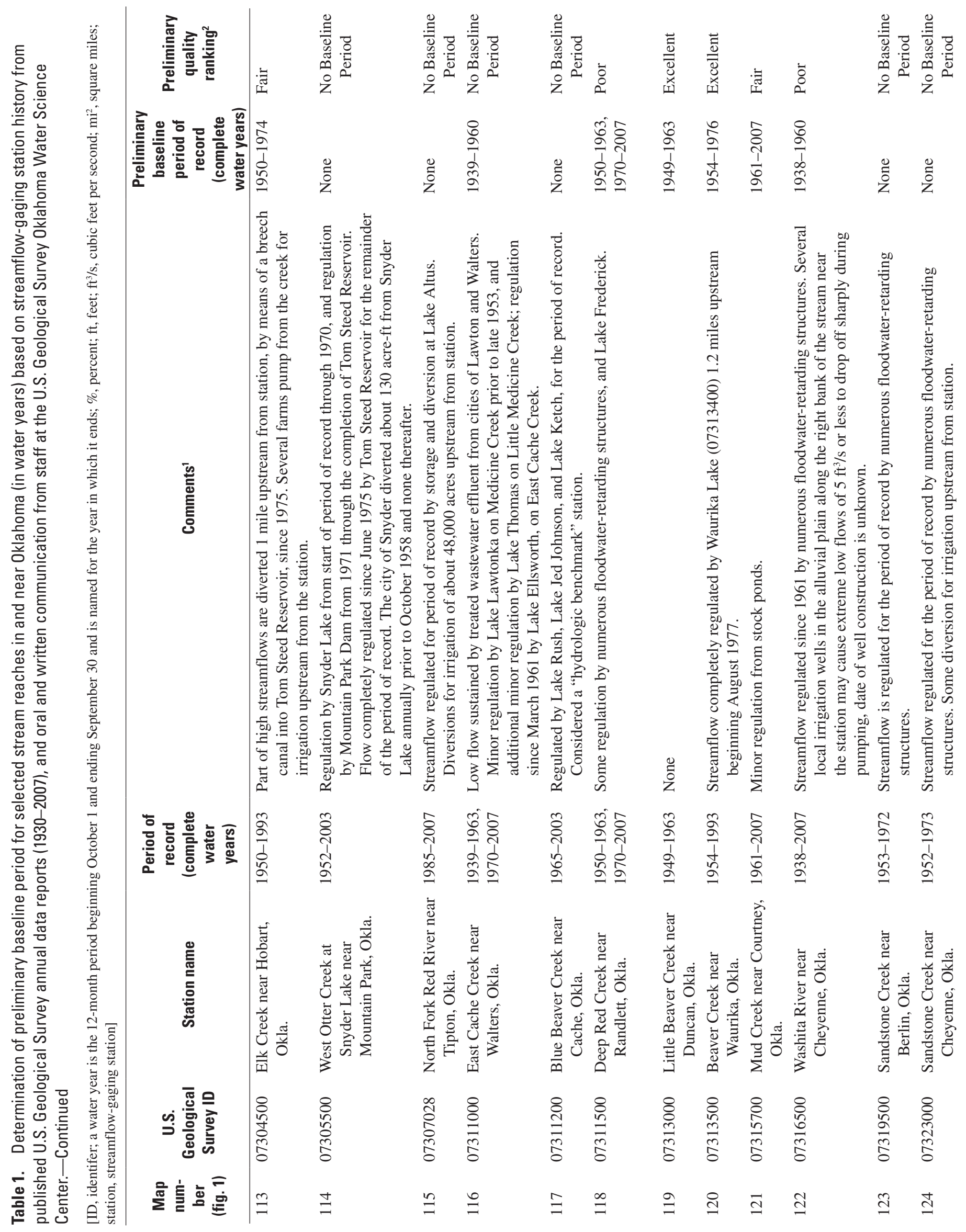




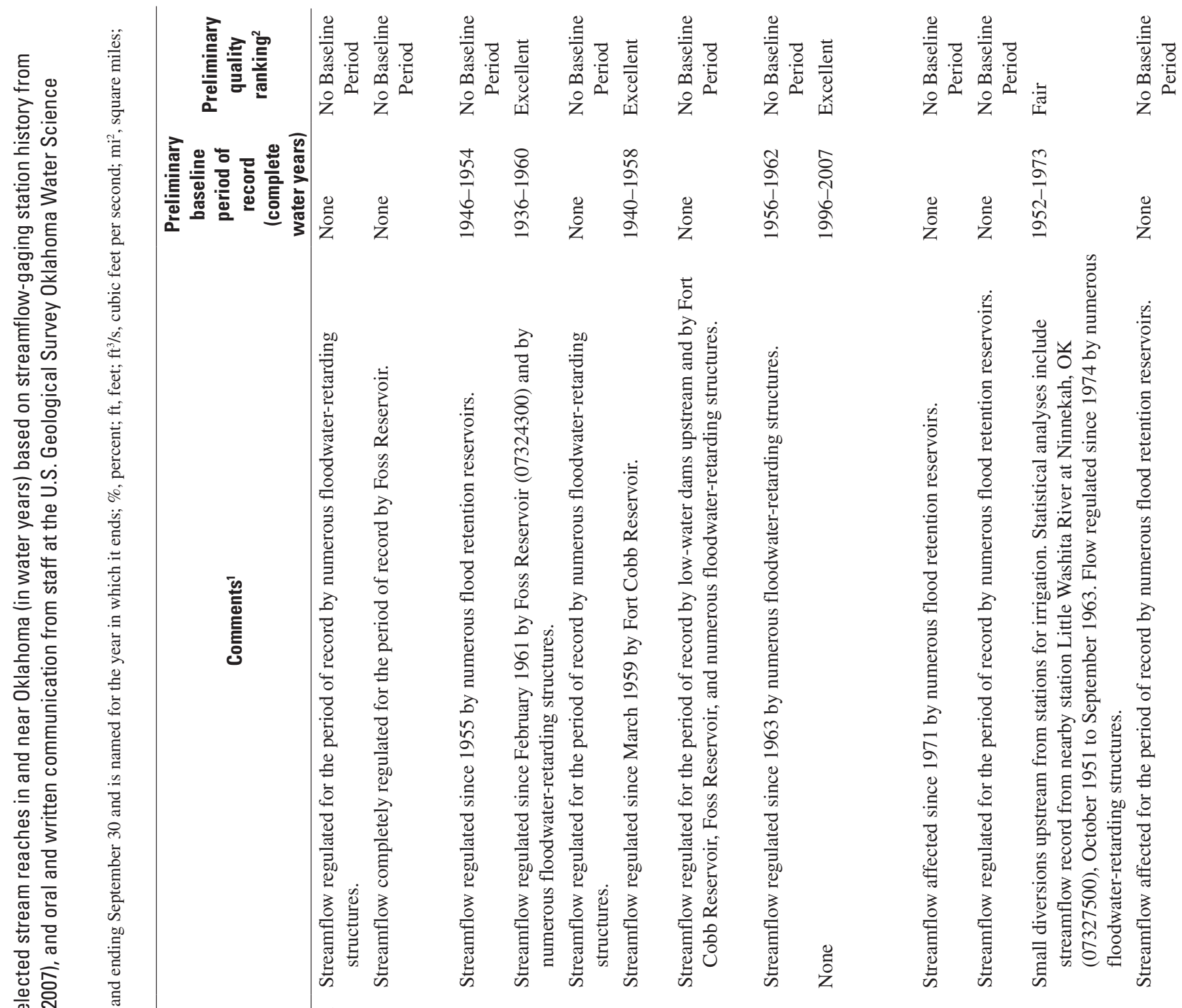

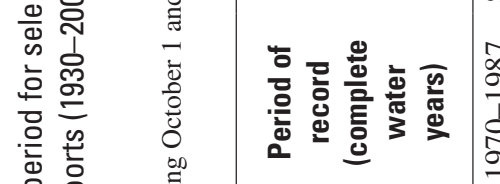

음 흥

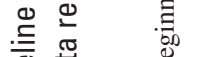

(1)

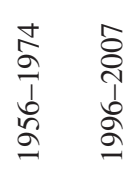

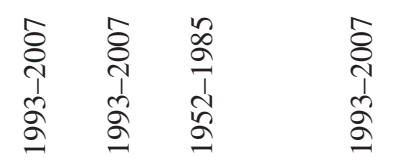

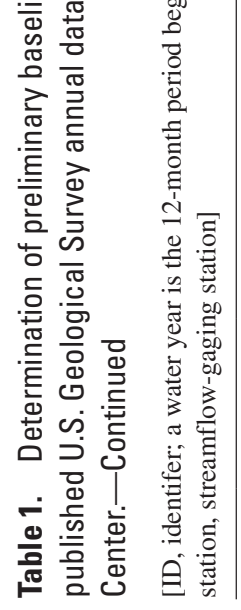

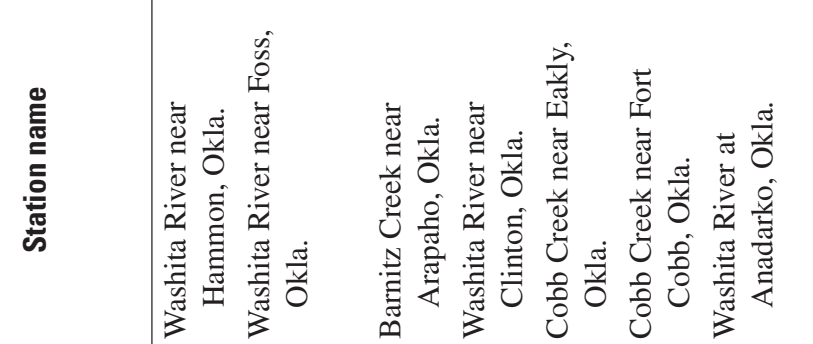

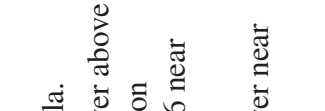

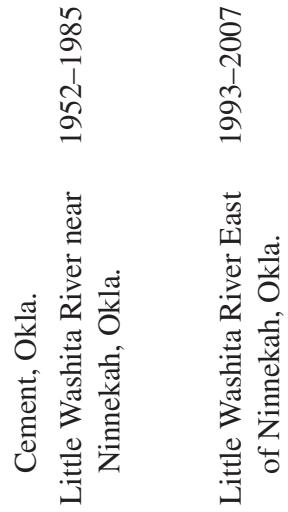

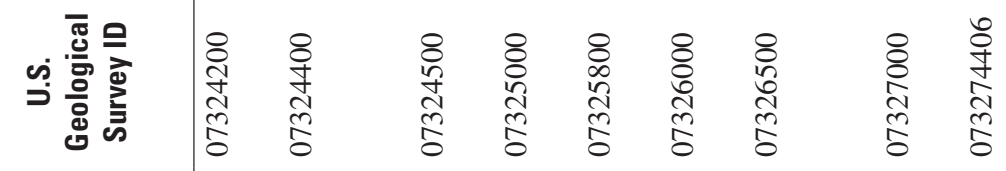

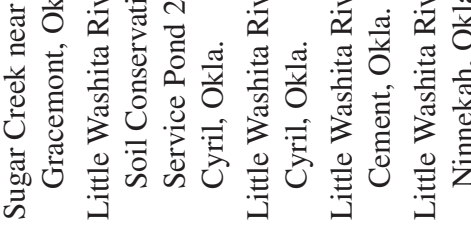

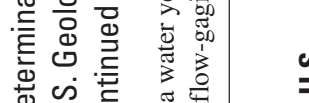

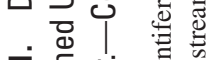
产訔离

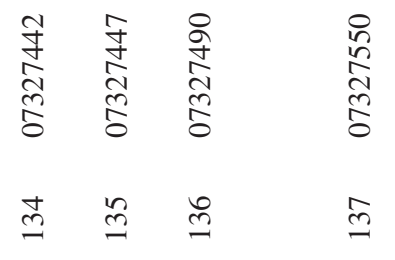




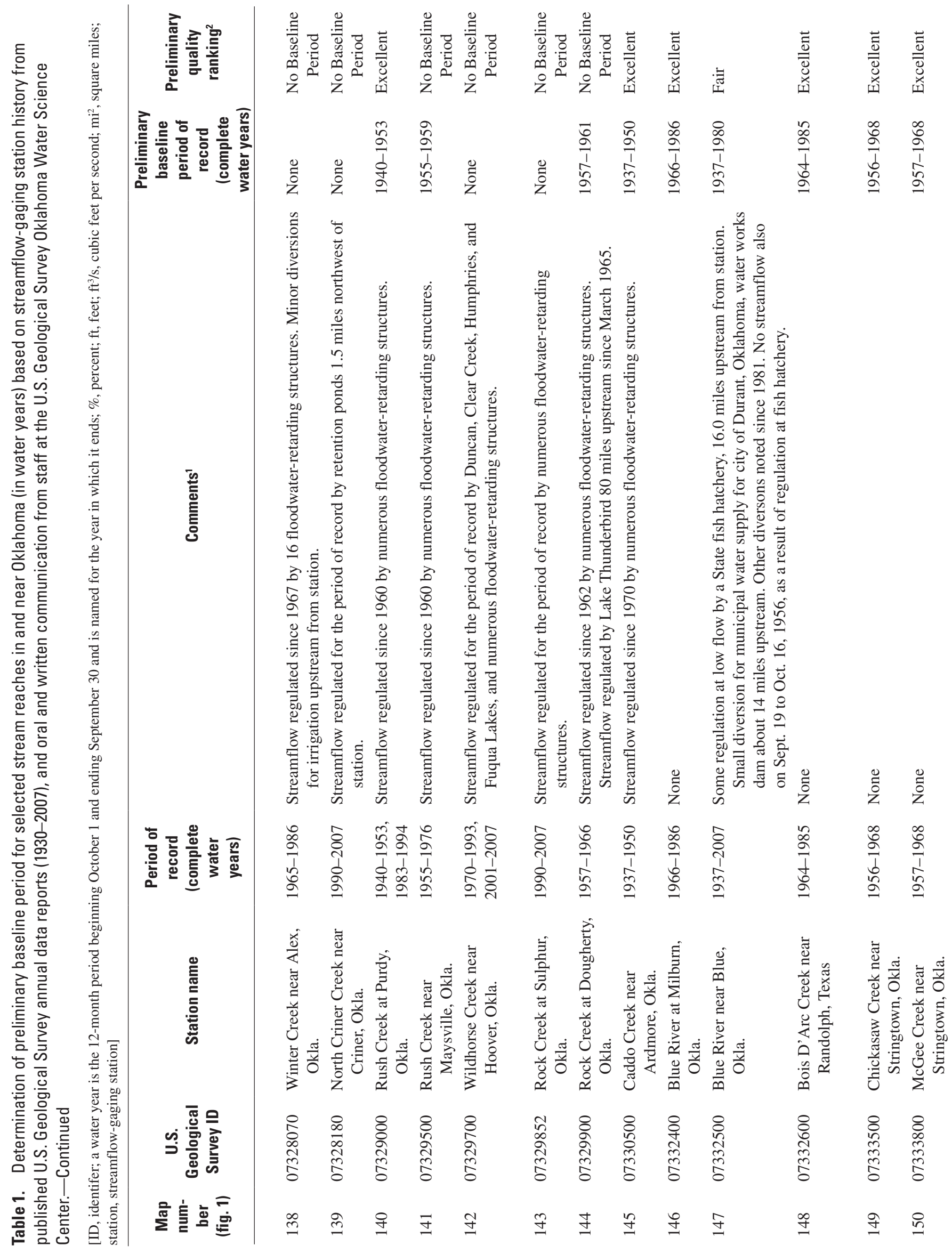




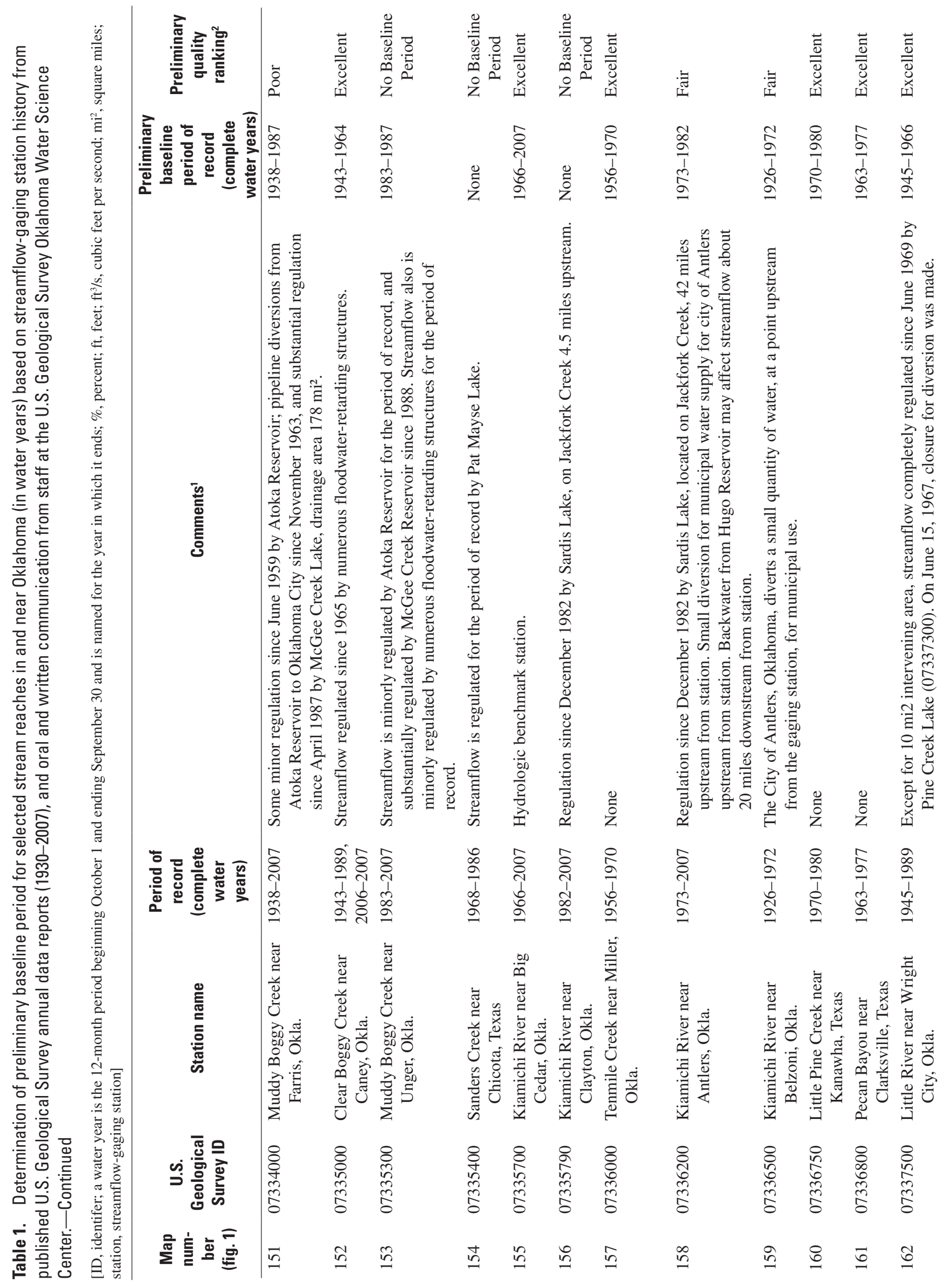




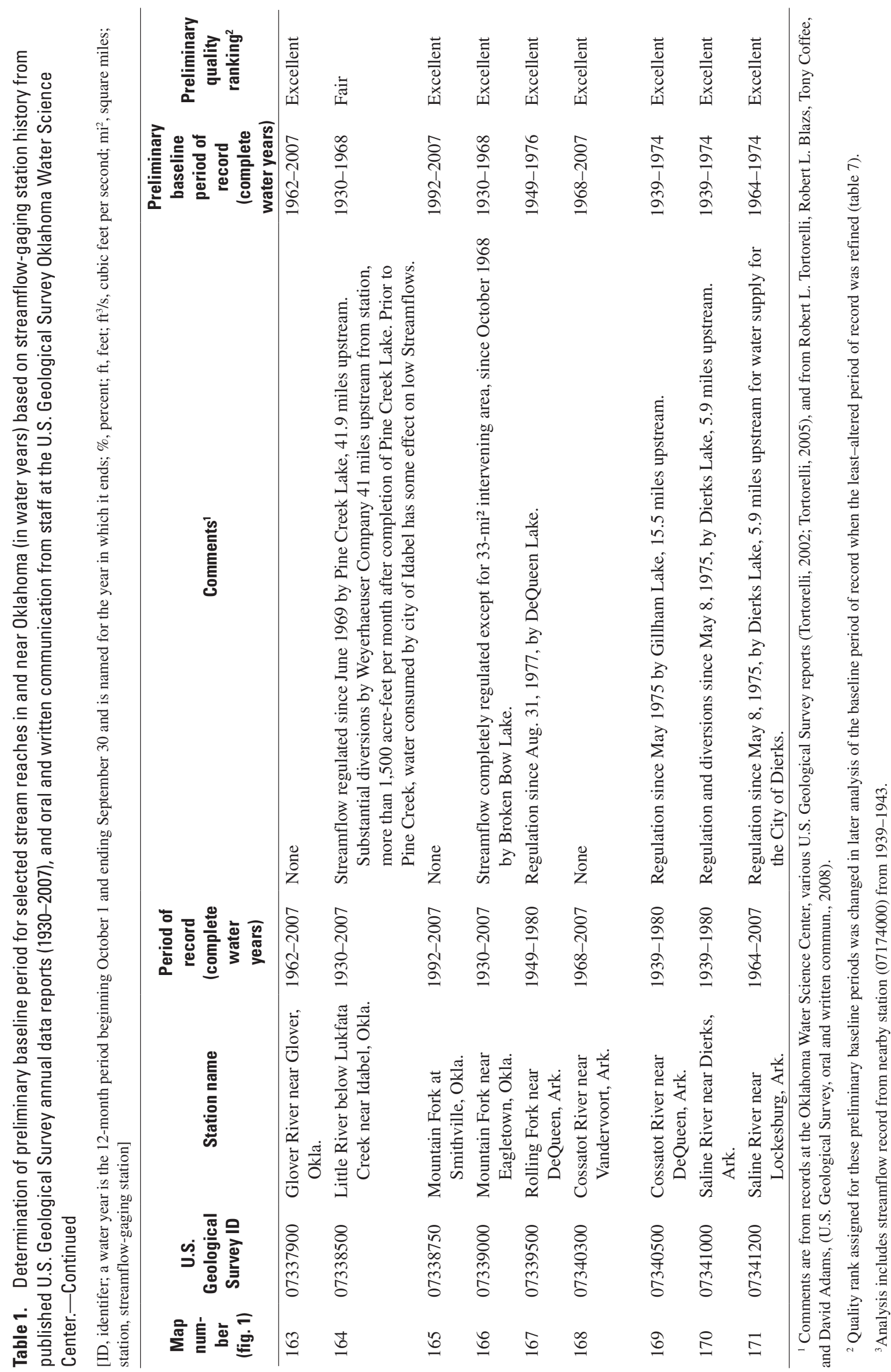


Table $2 \quad 37$

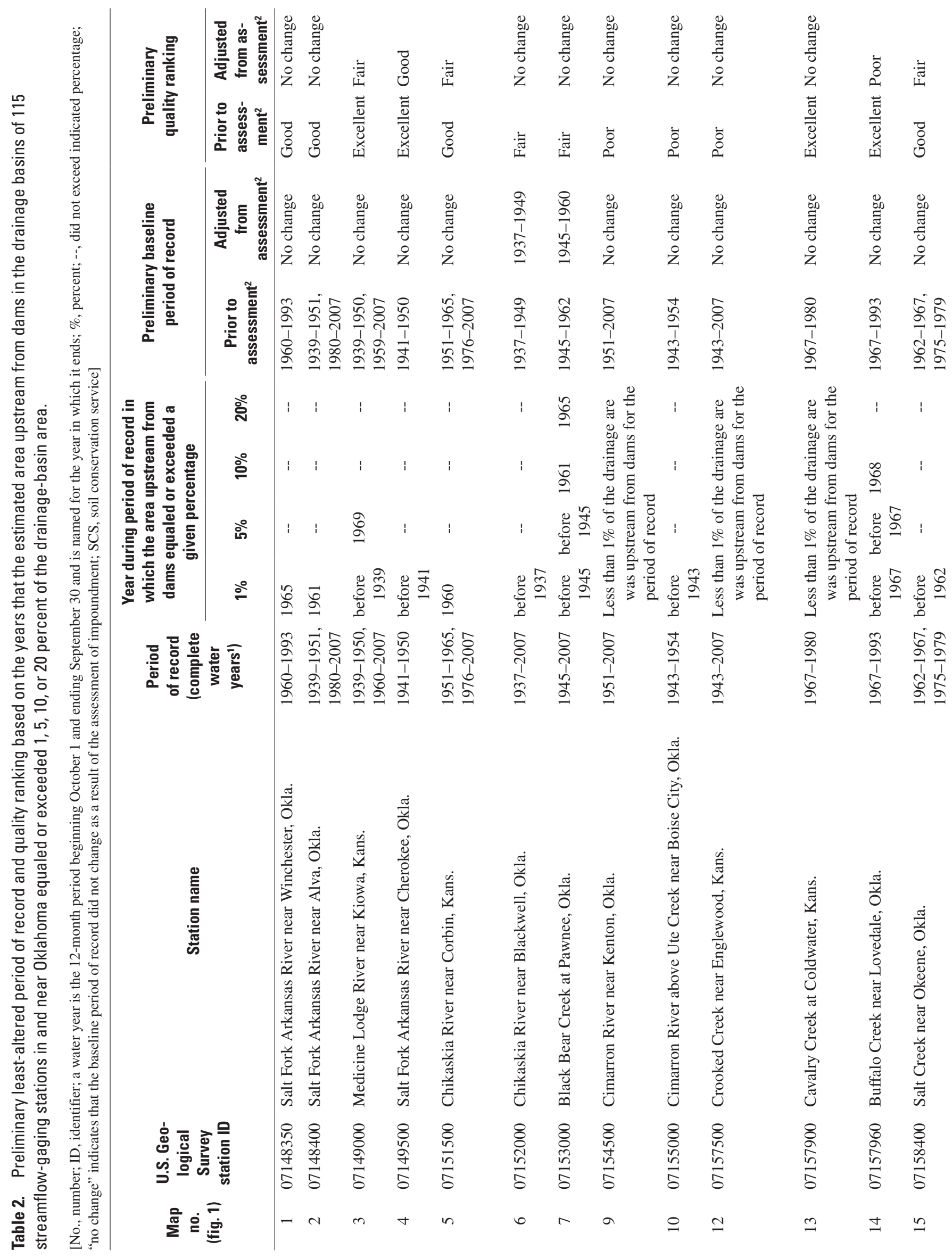




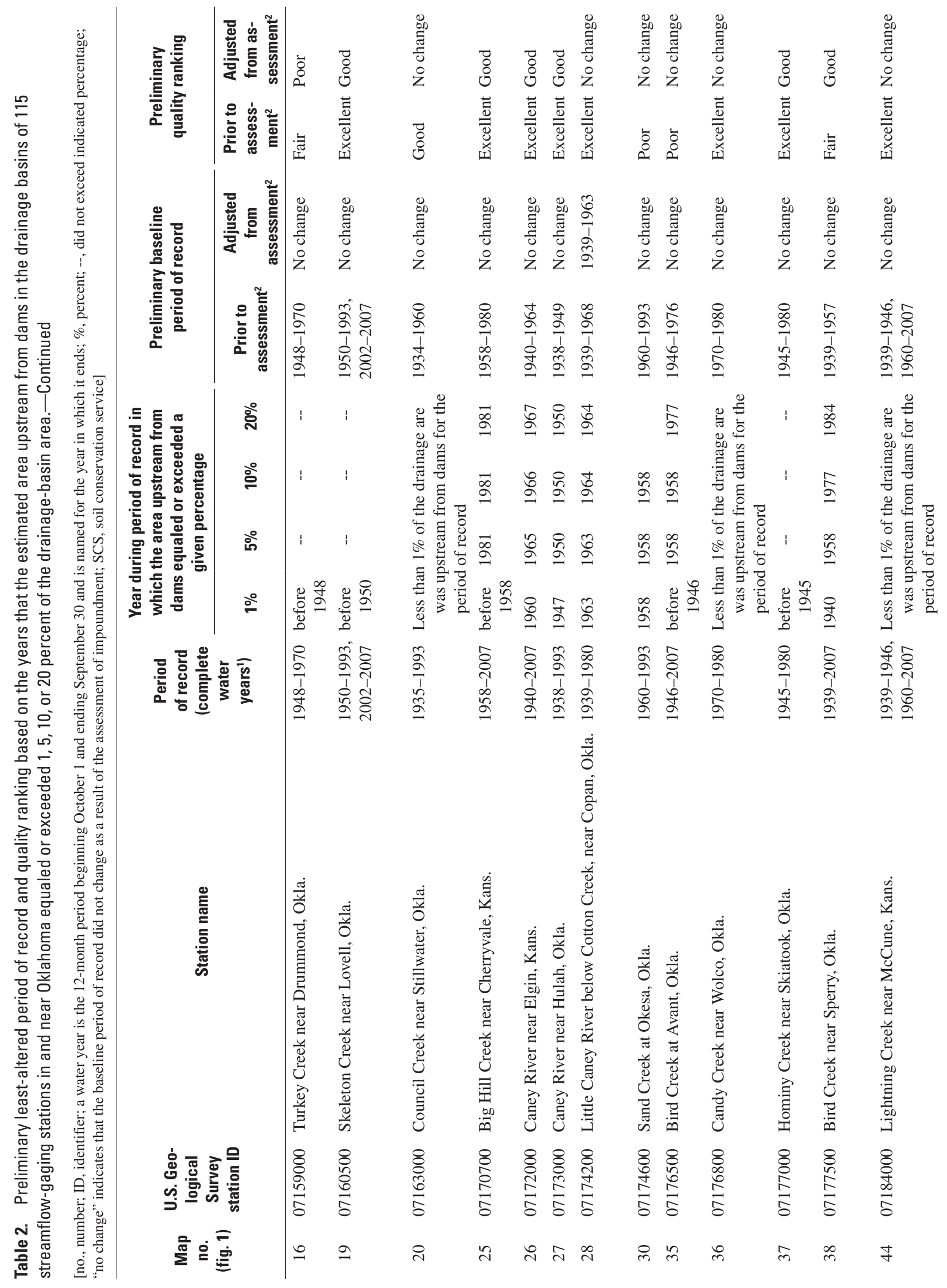




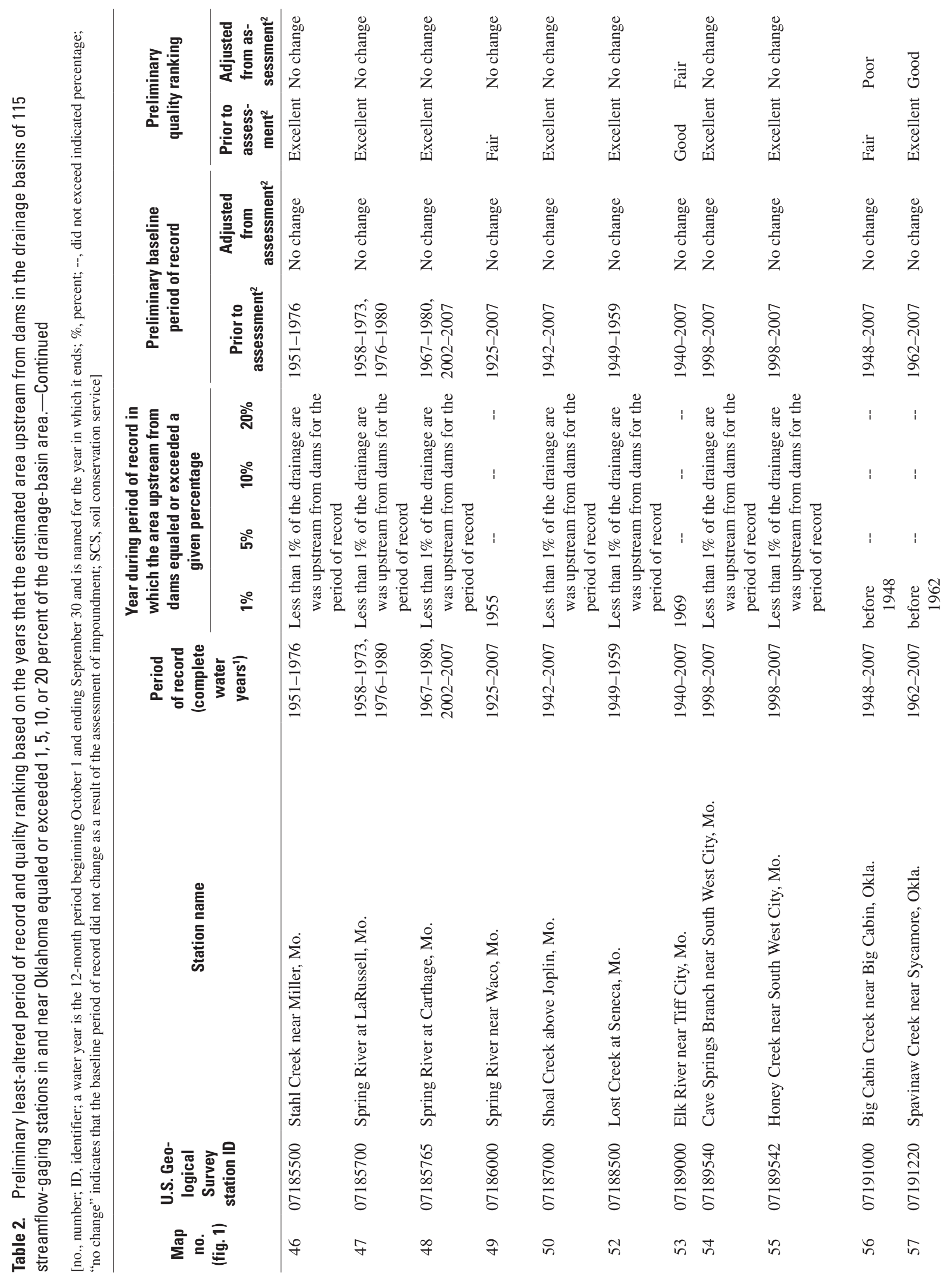




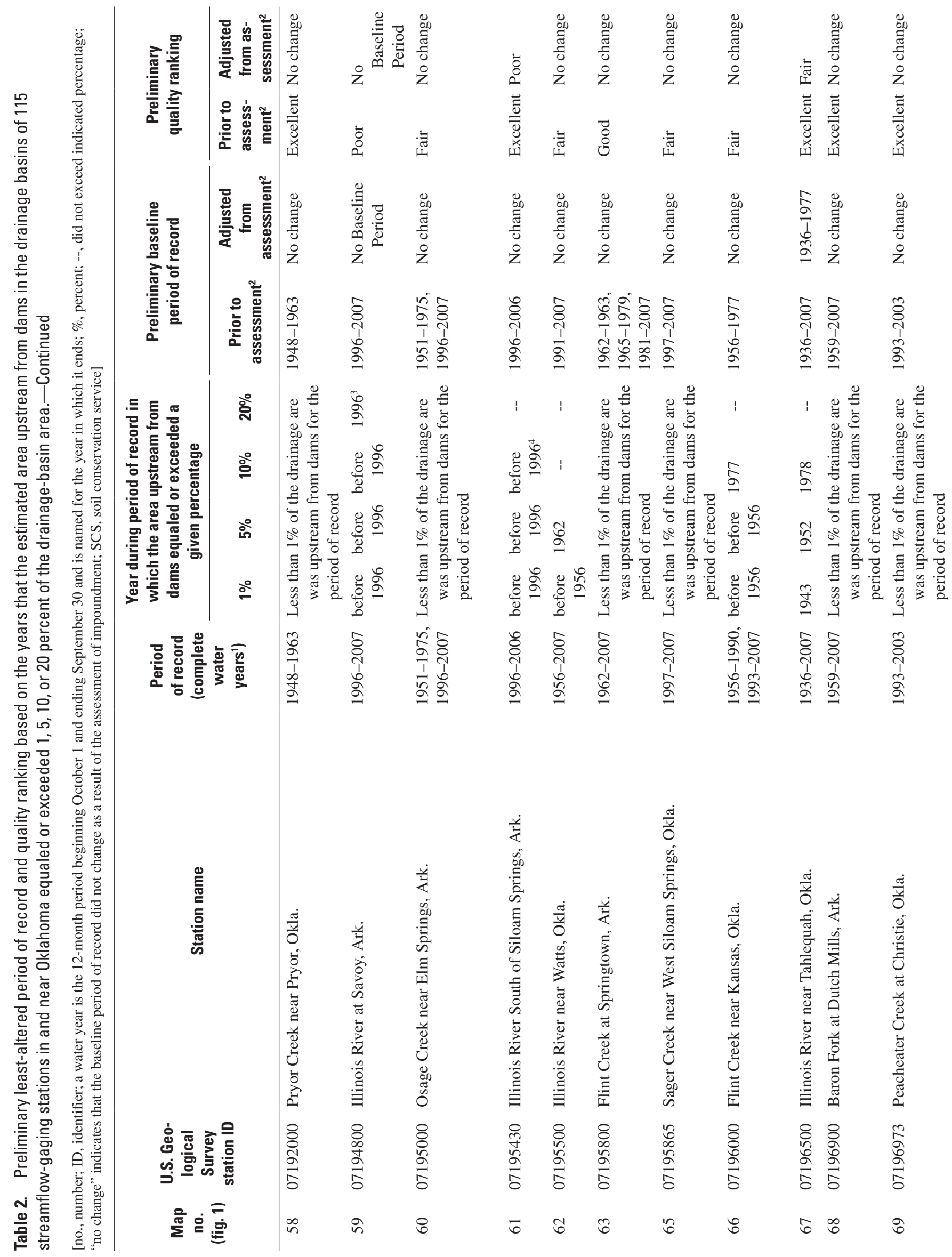




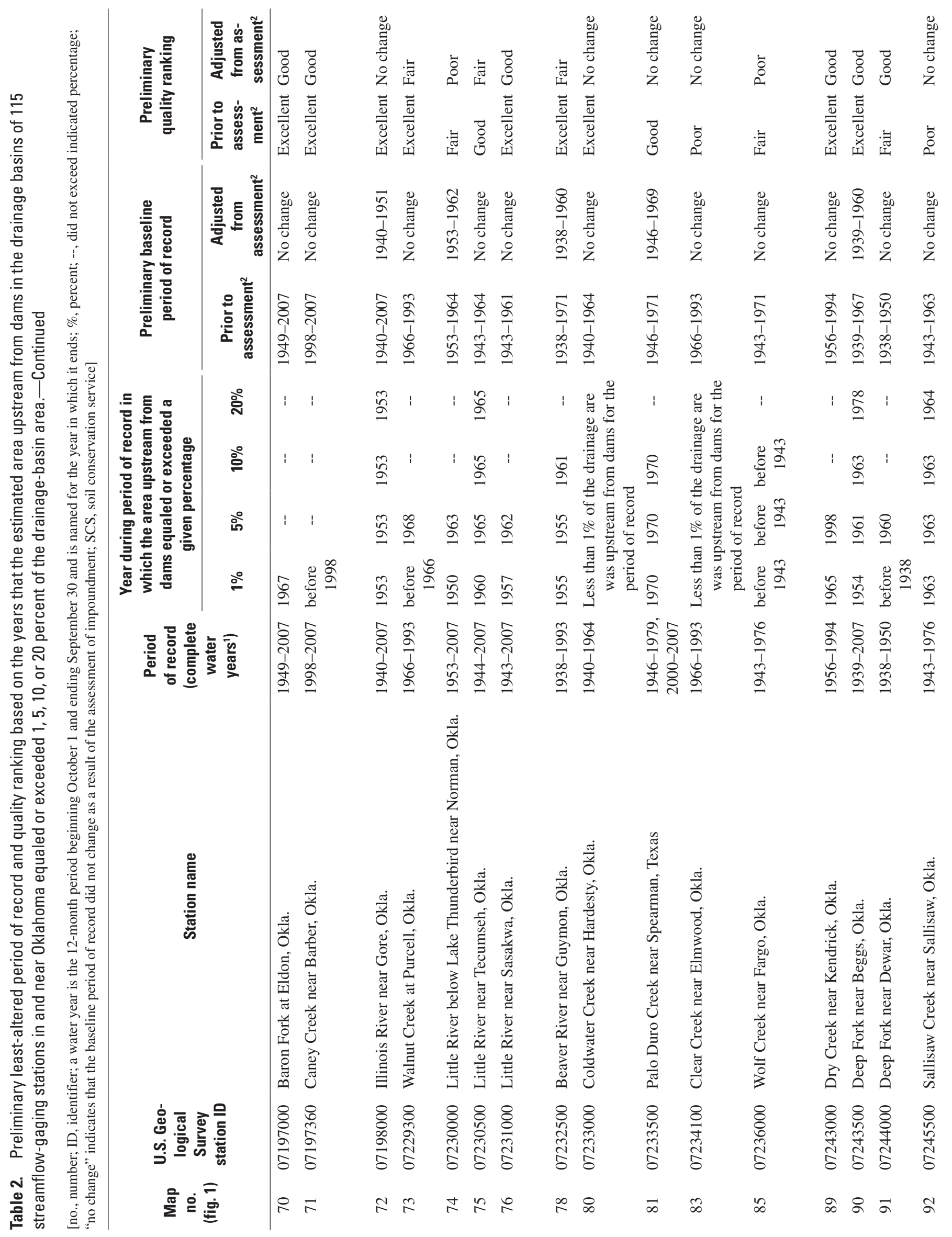




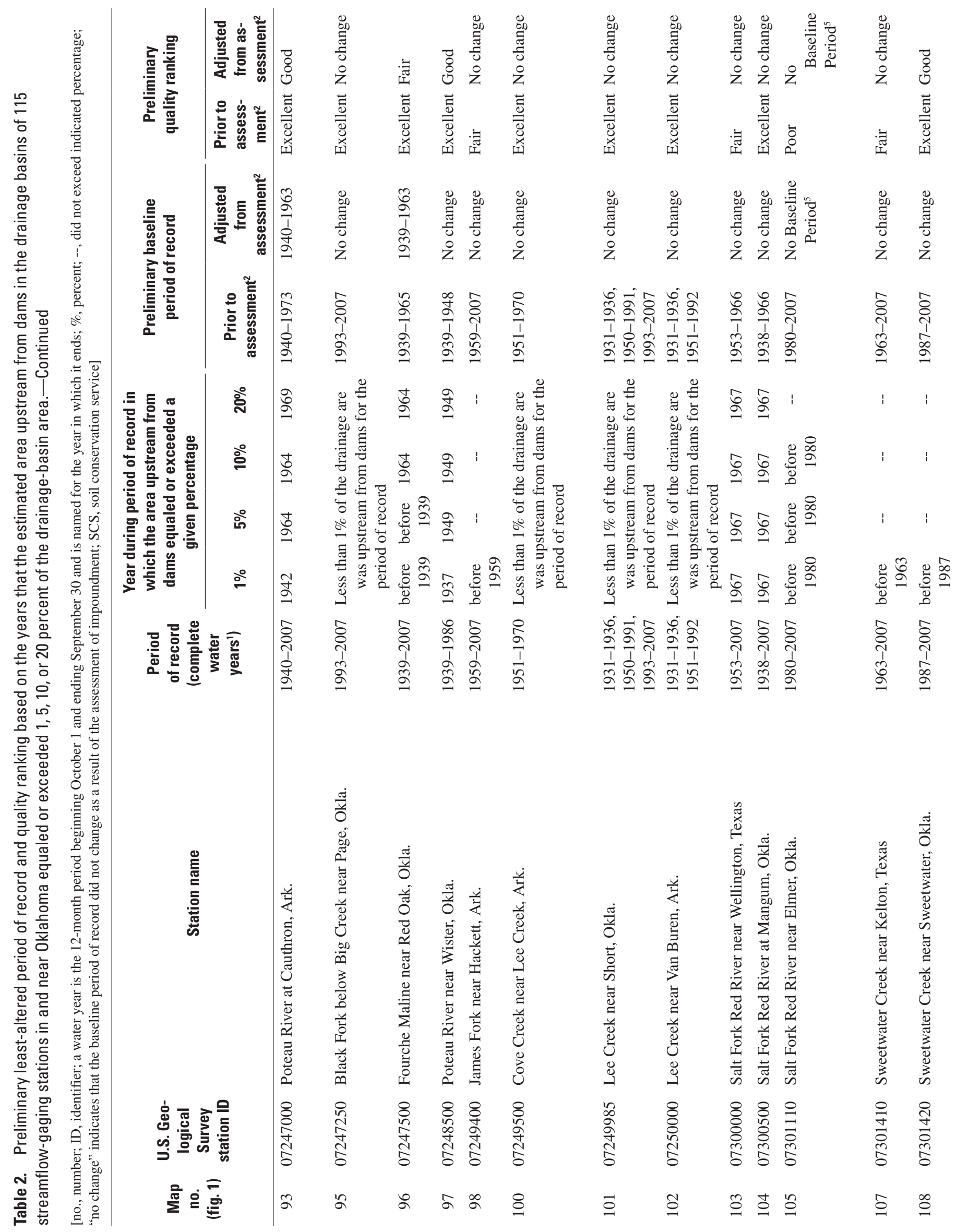




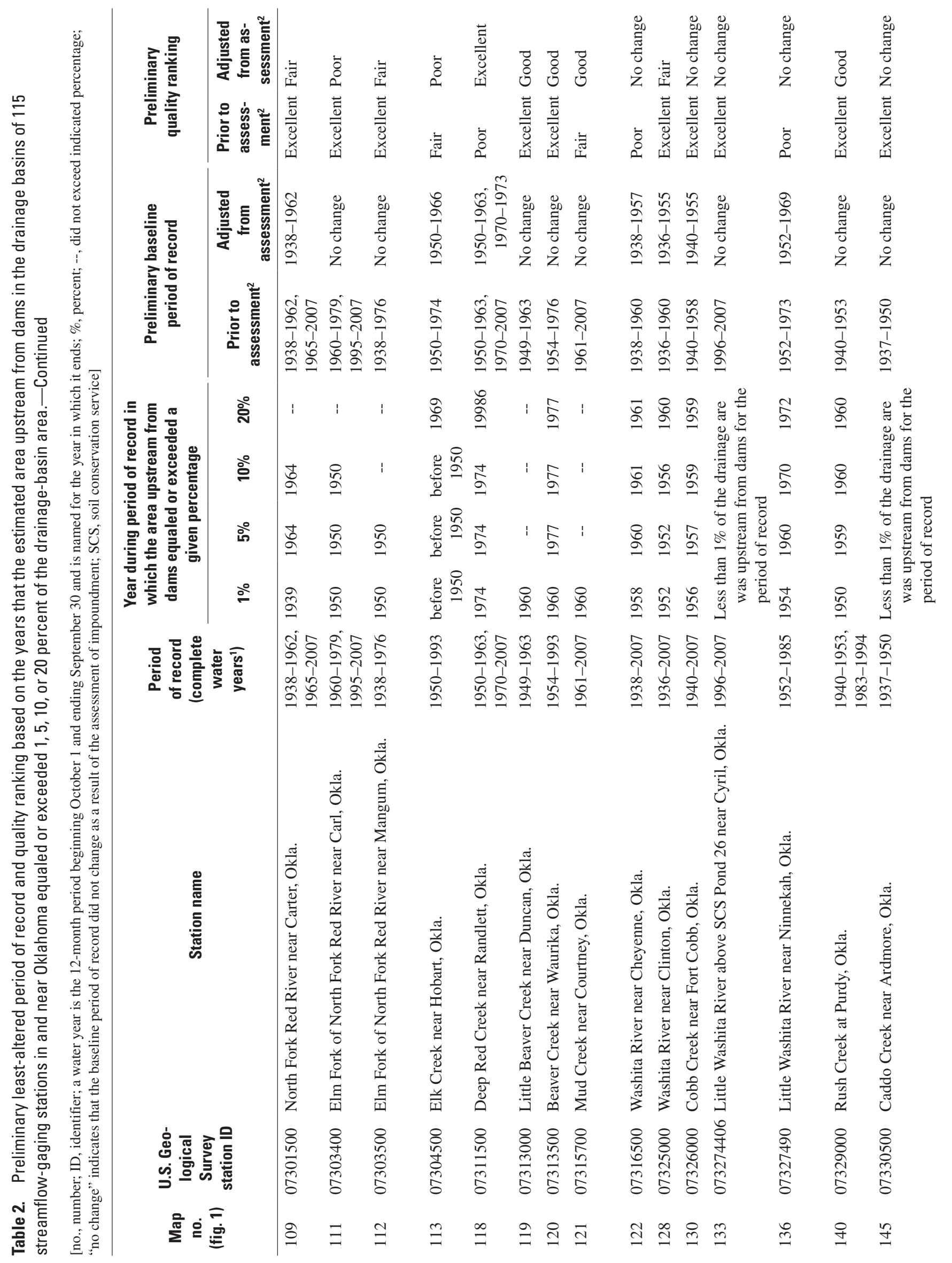




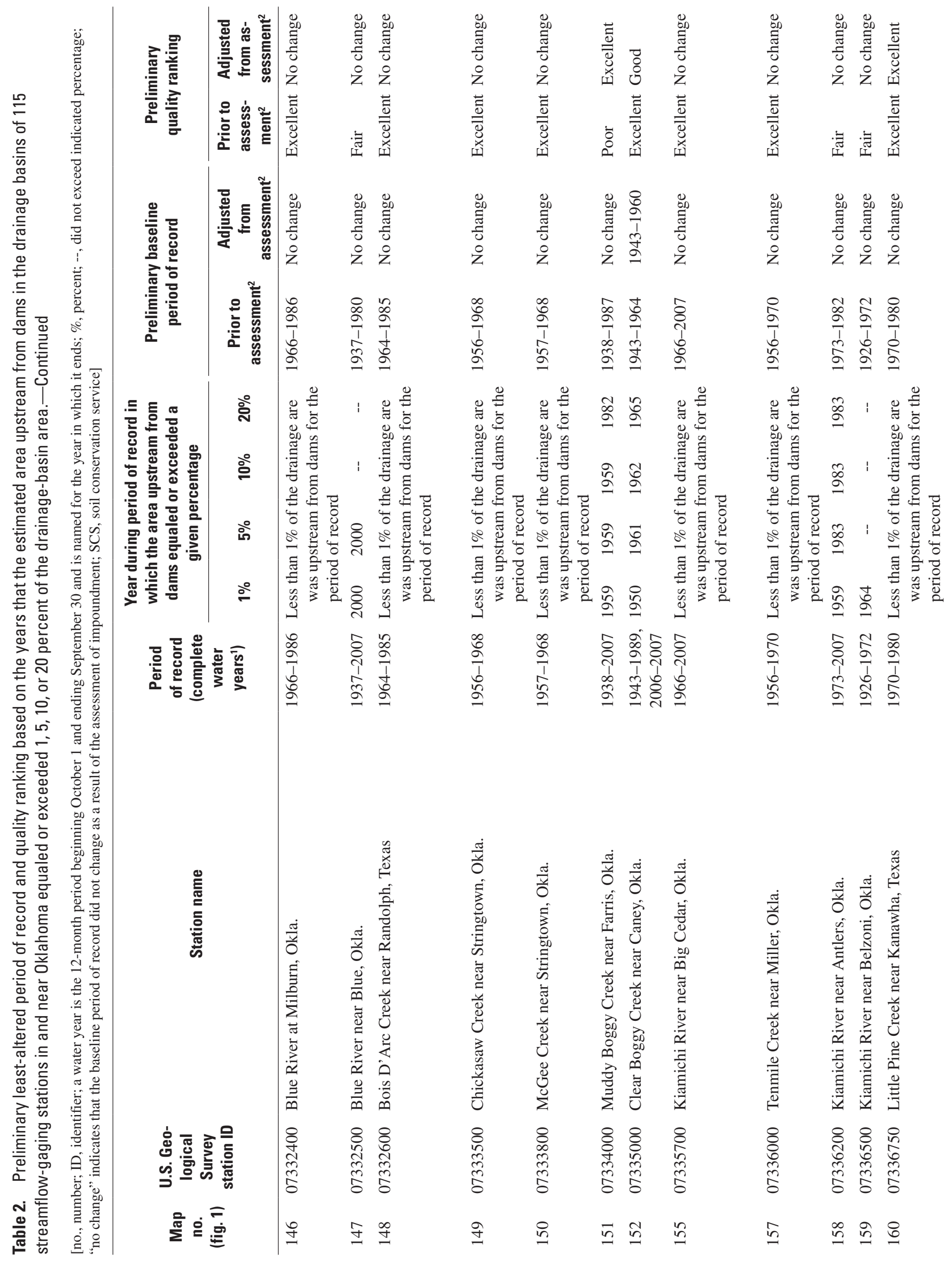




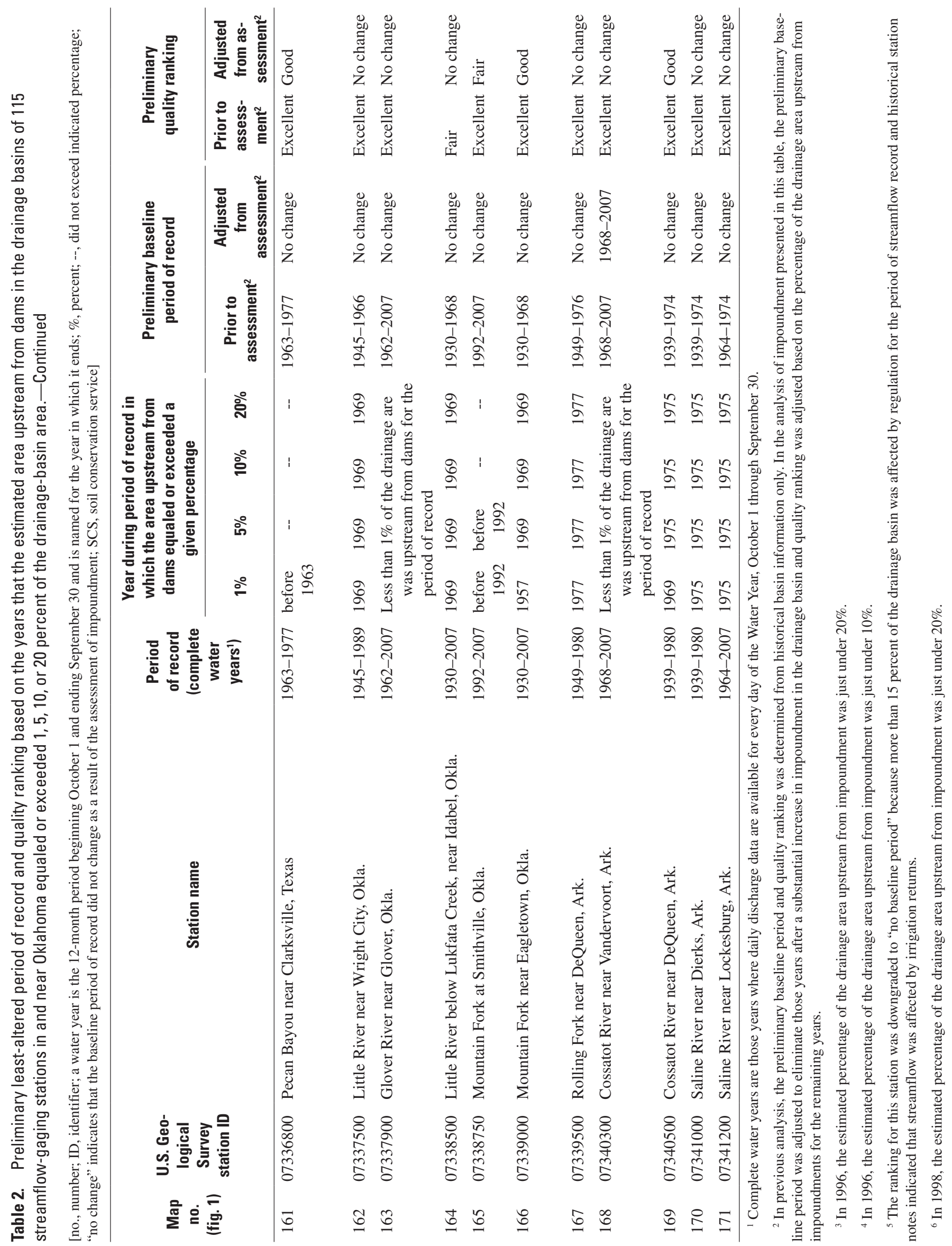




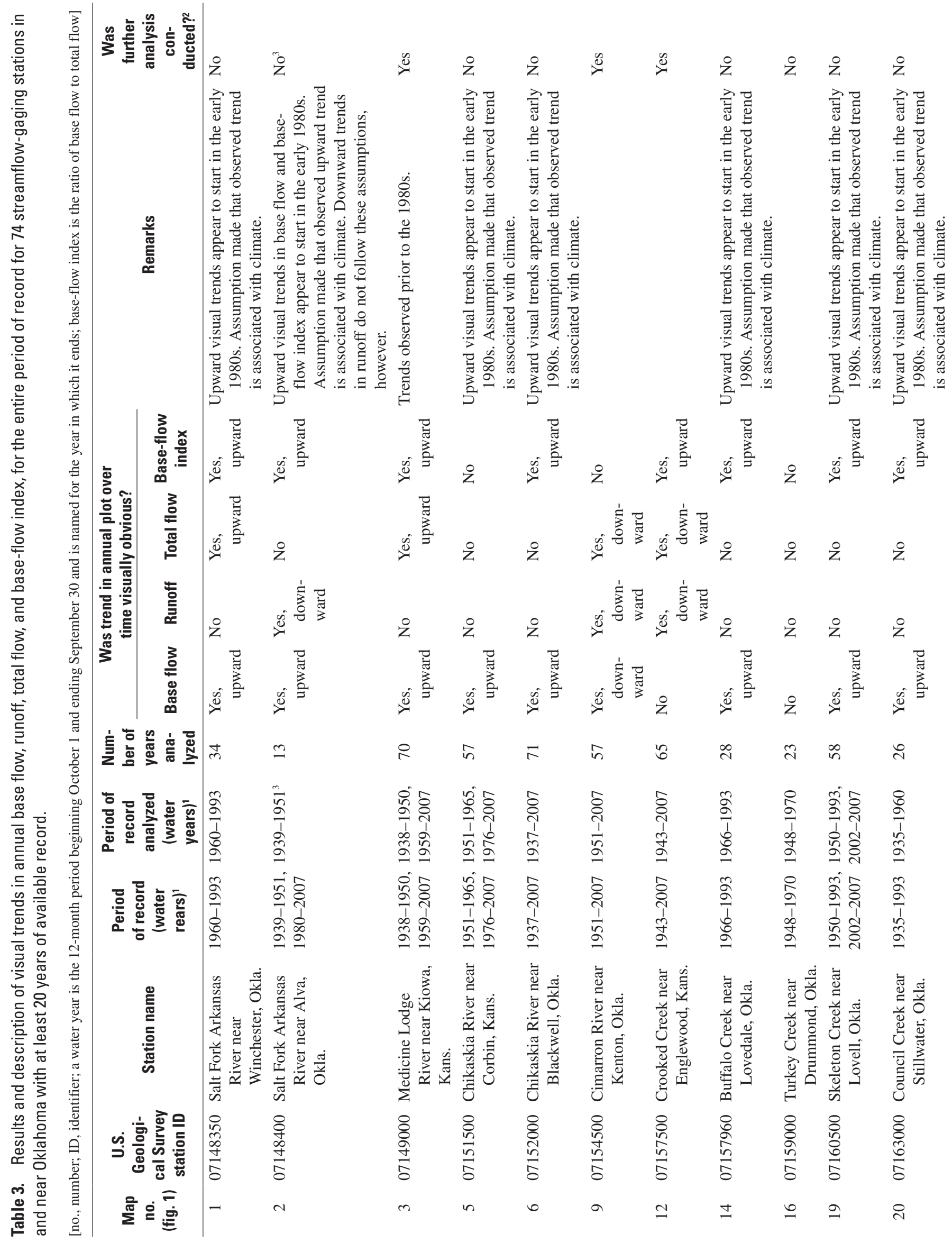




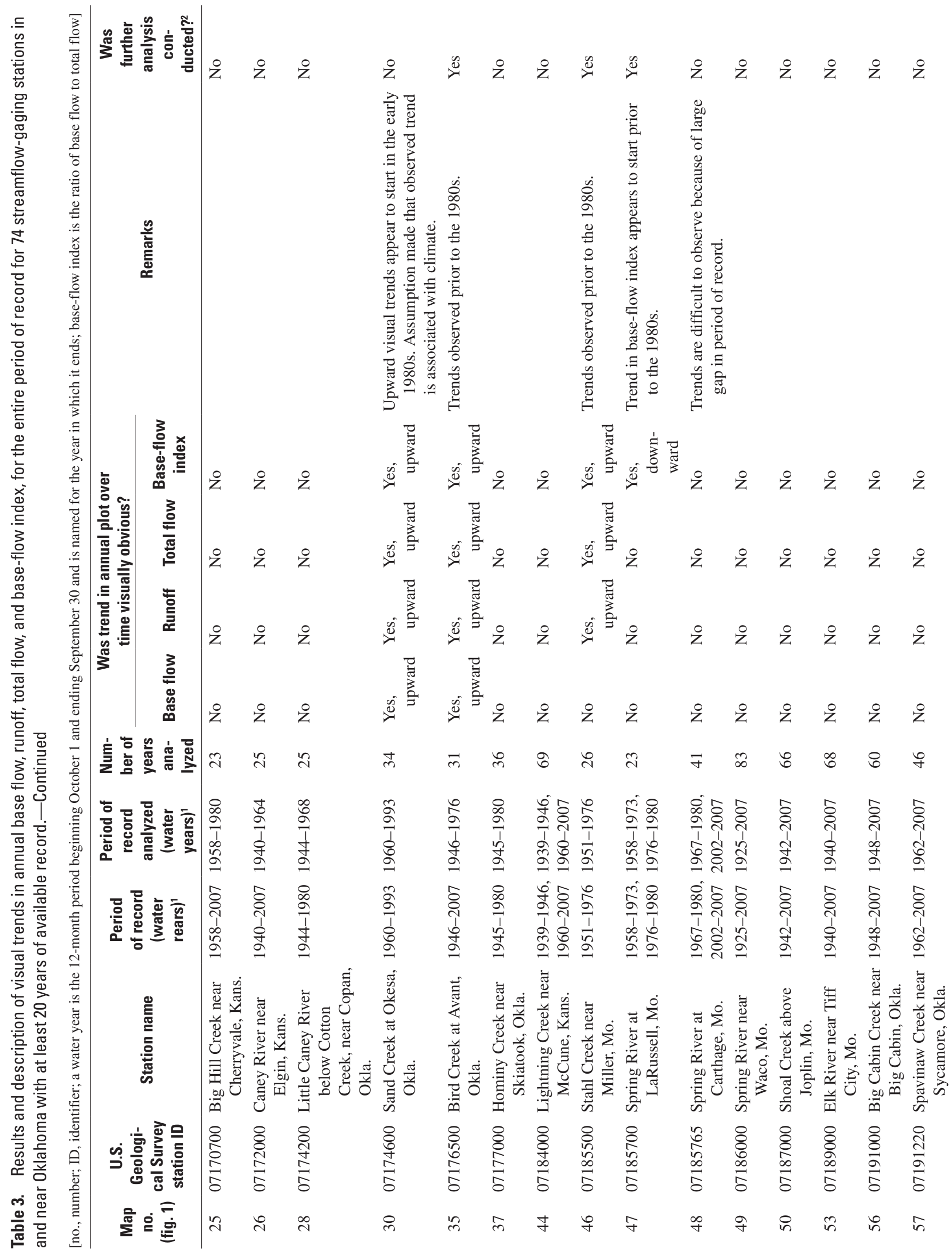




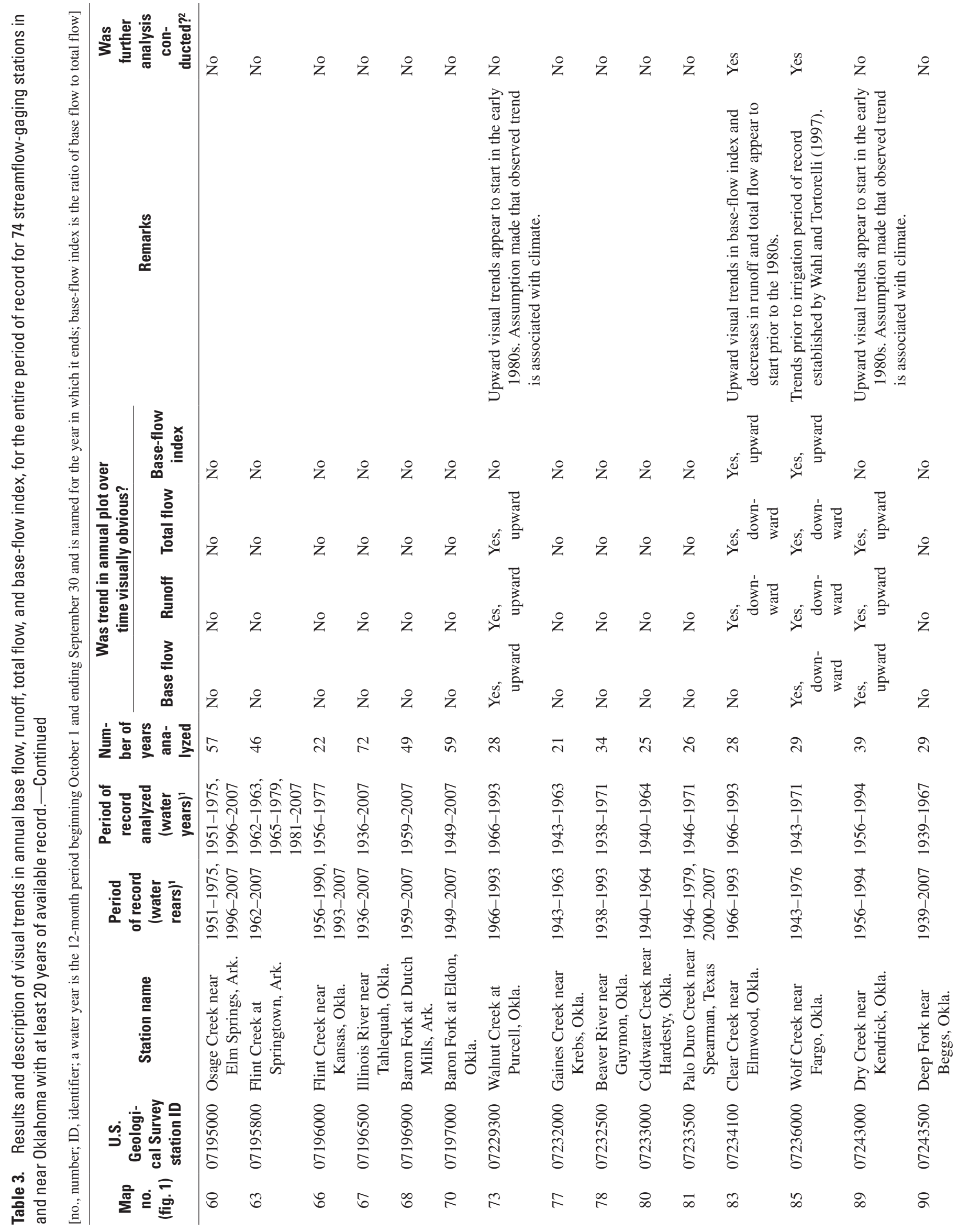




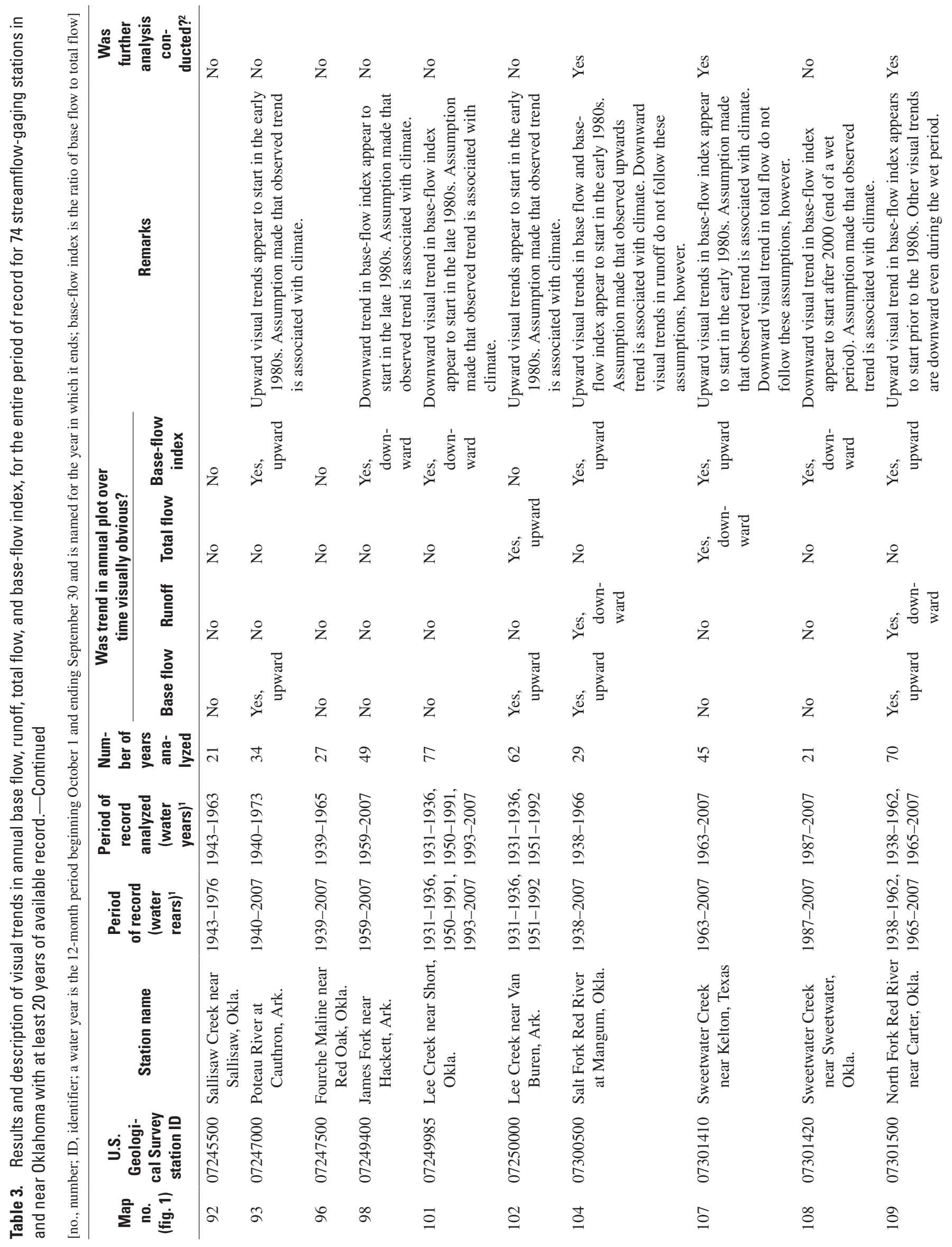




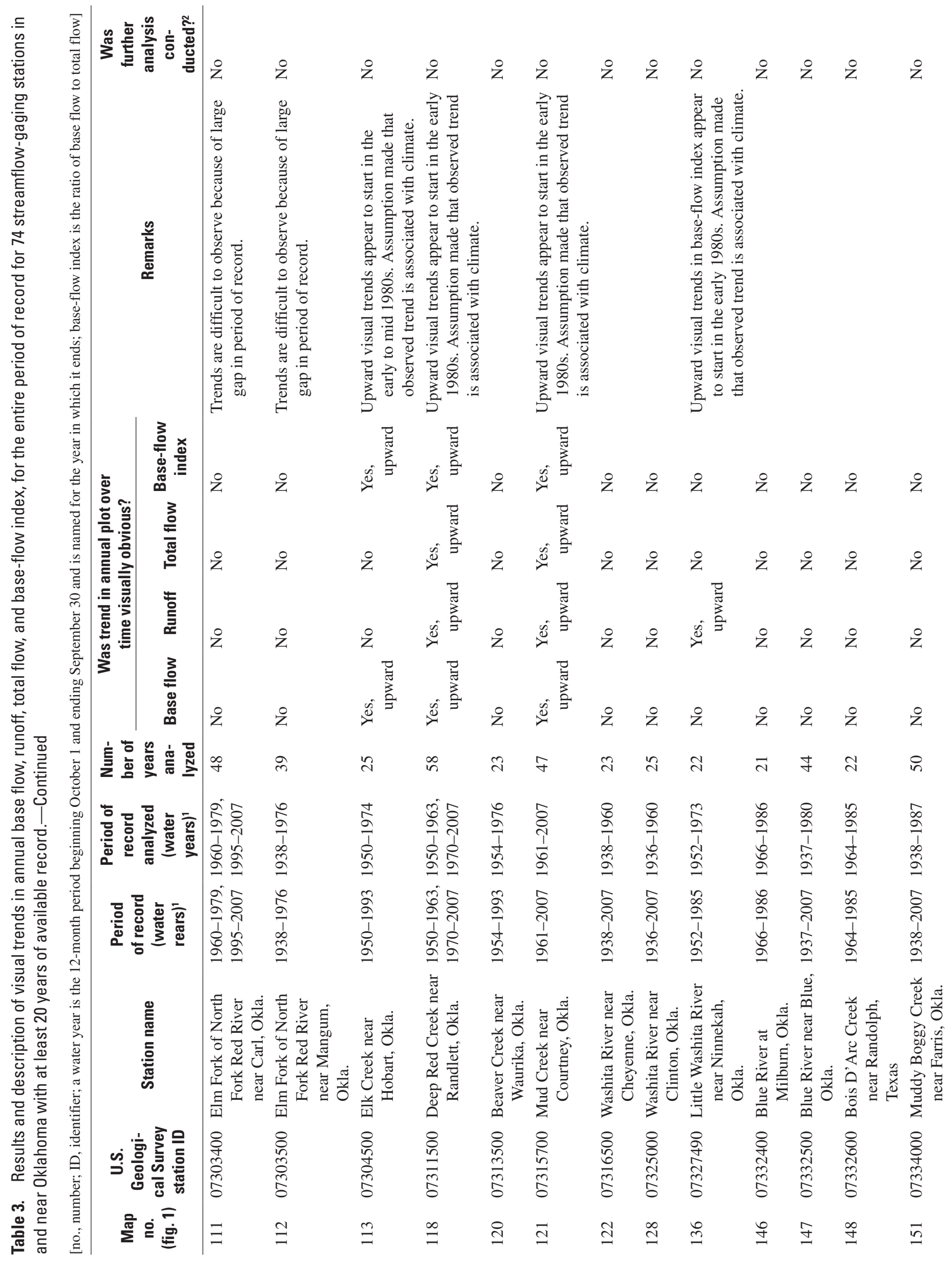




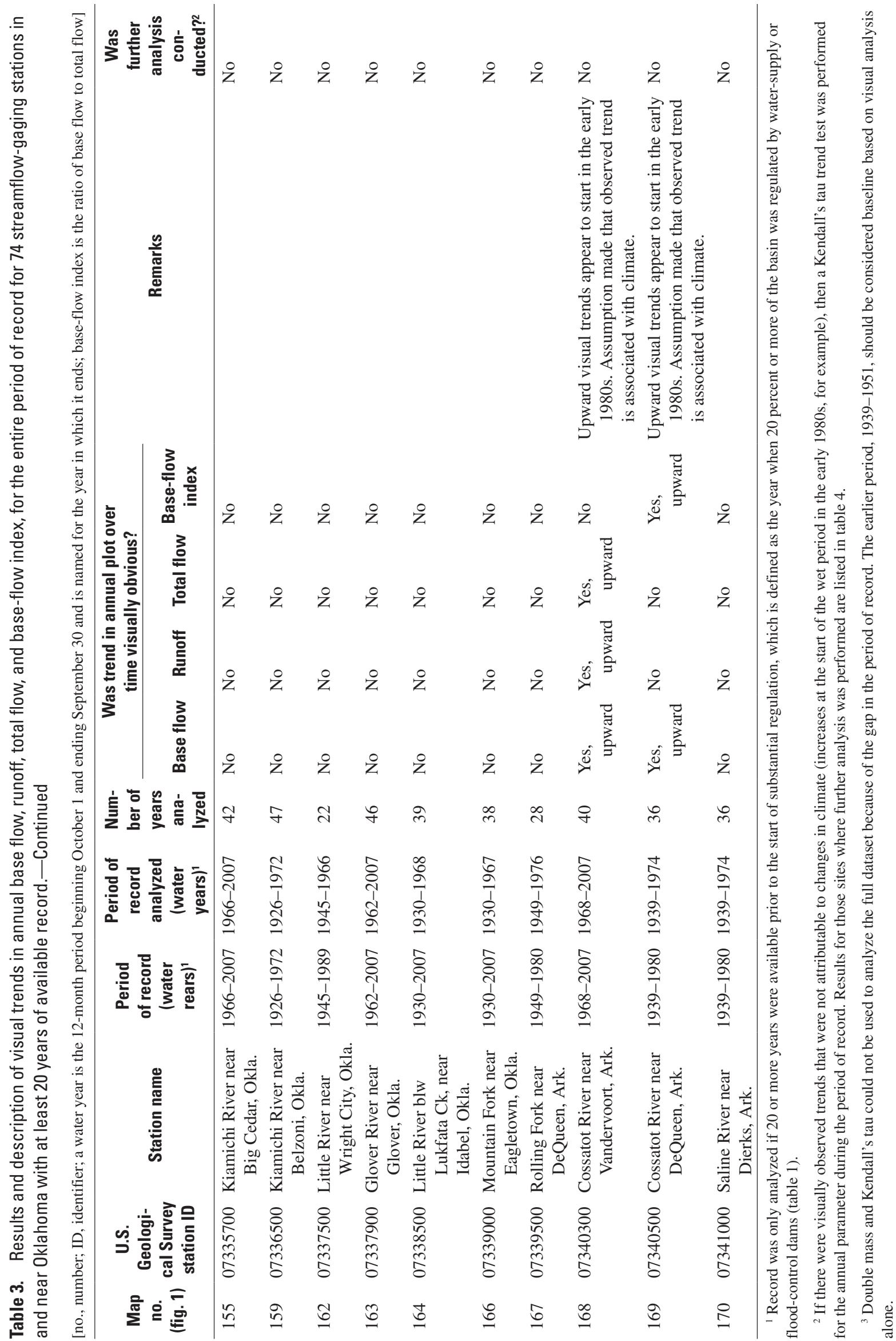




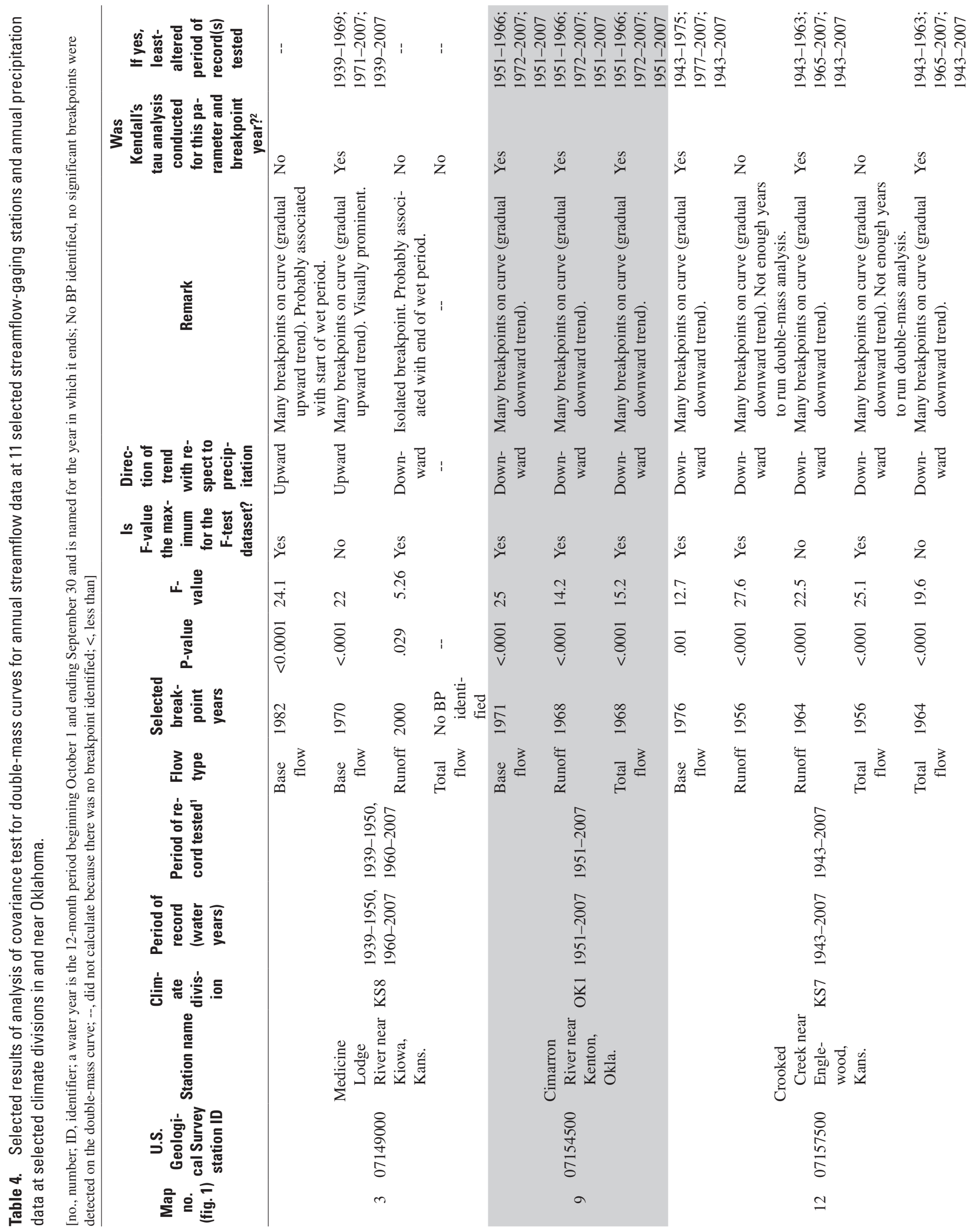




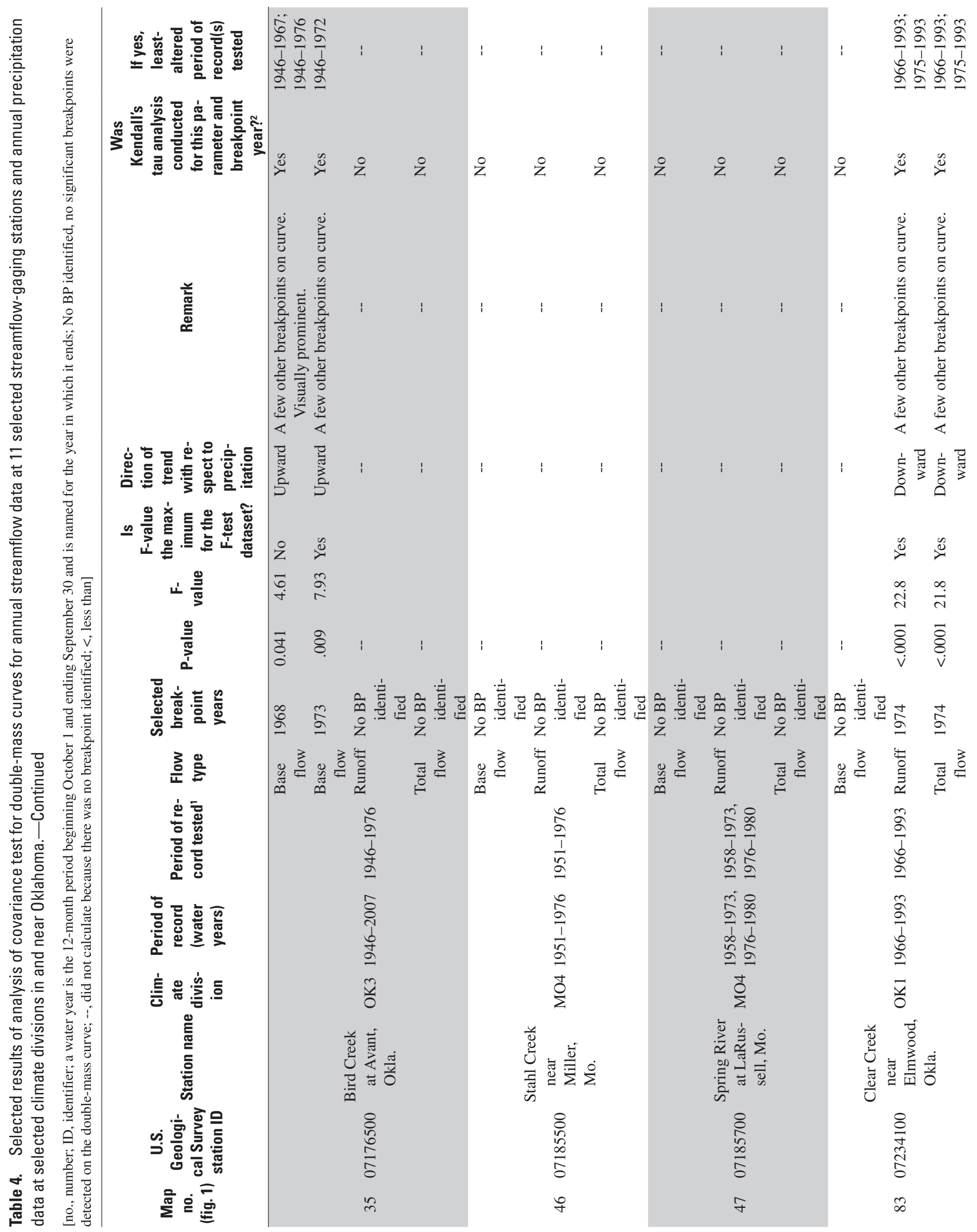




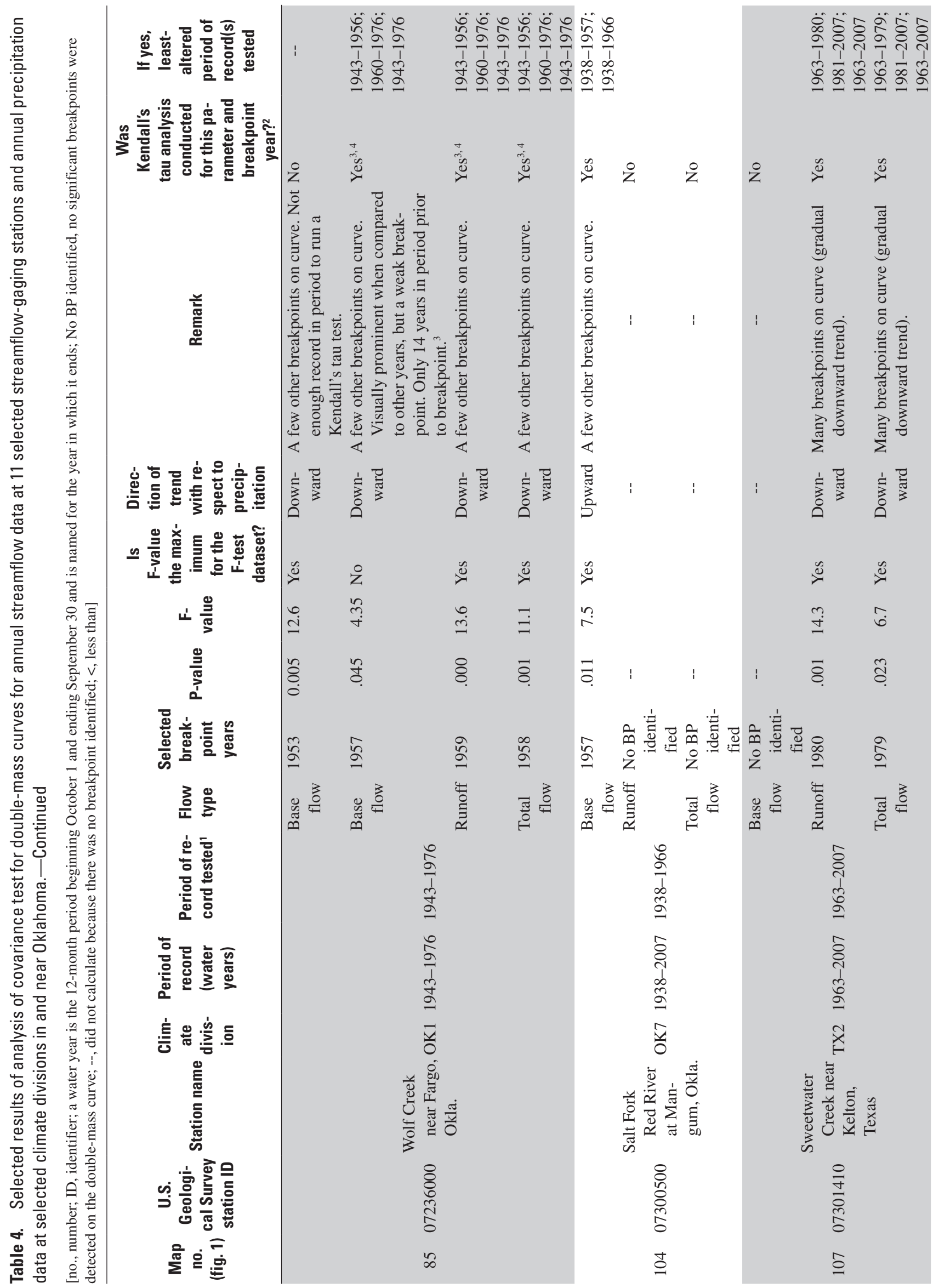




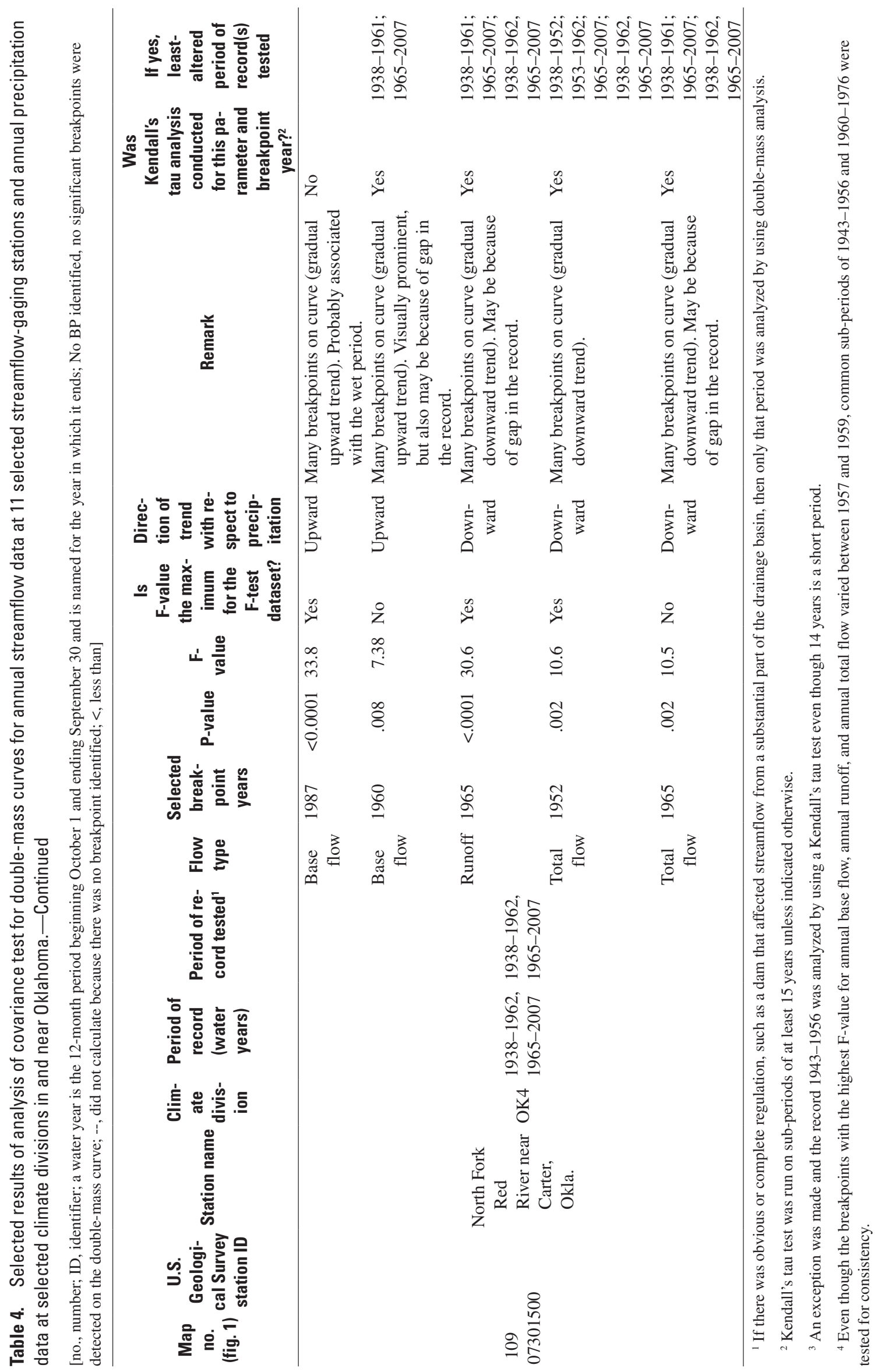




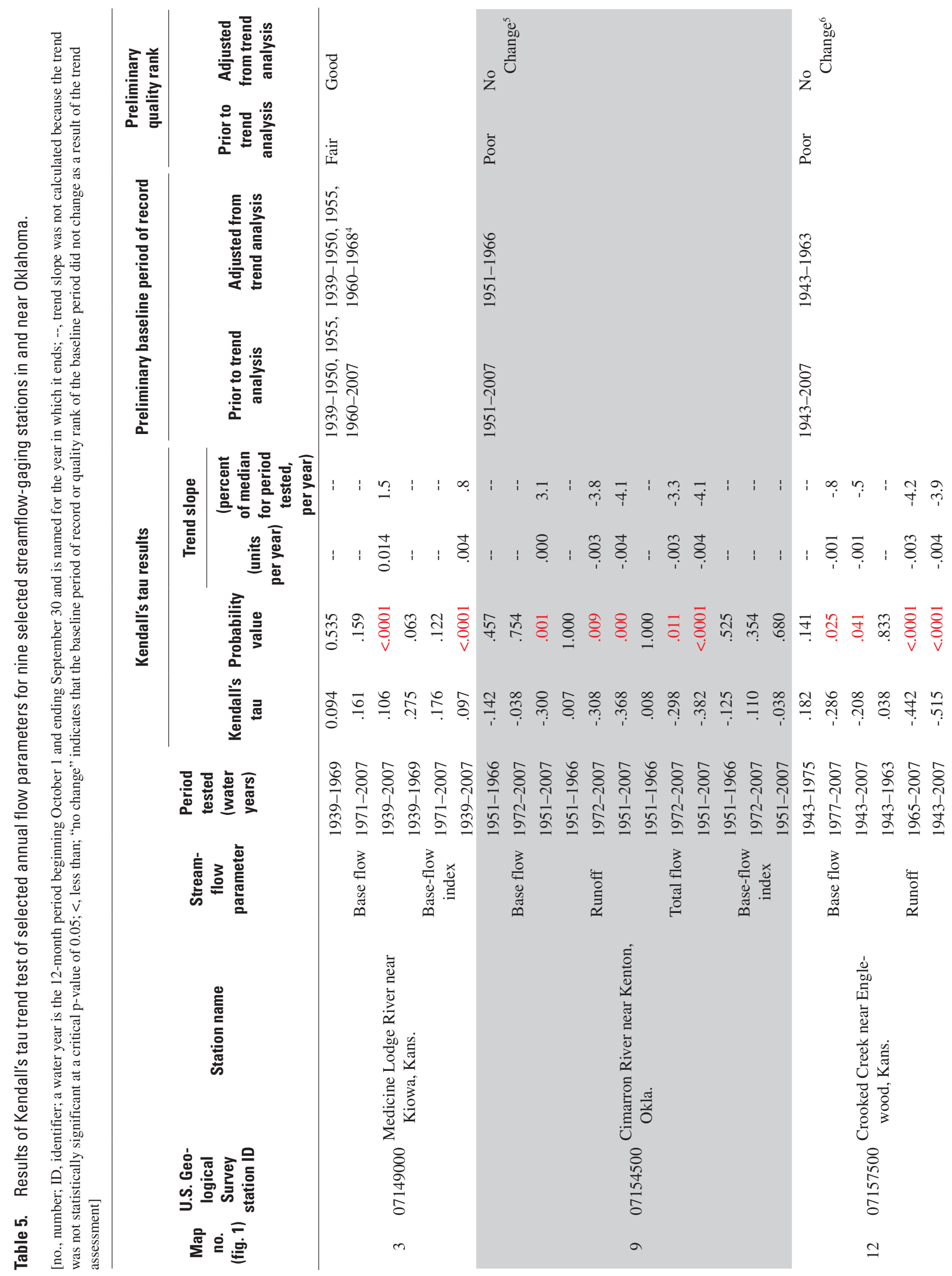




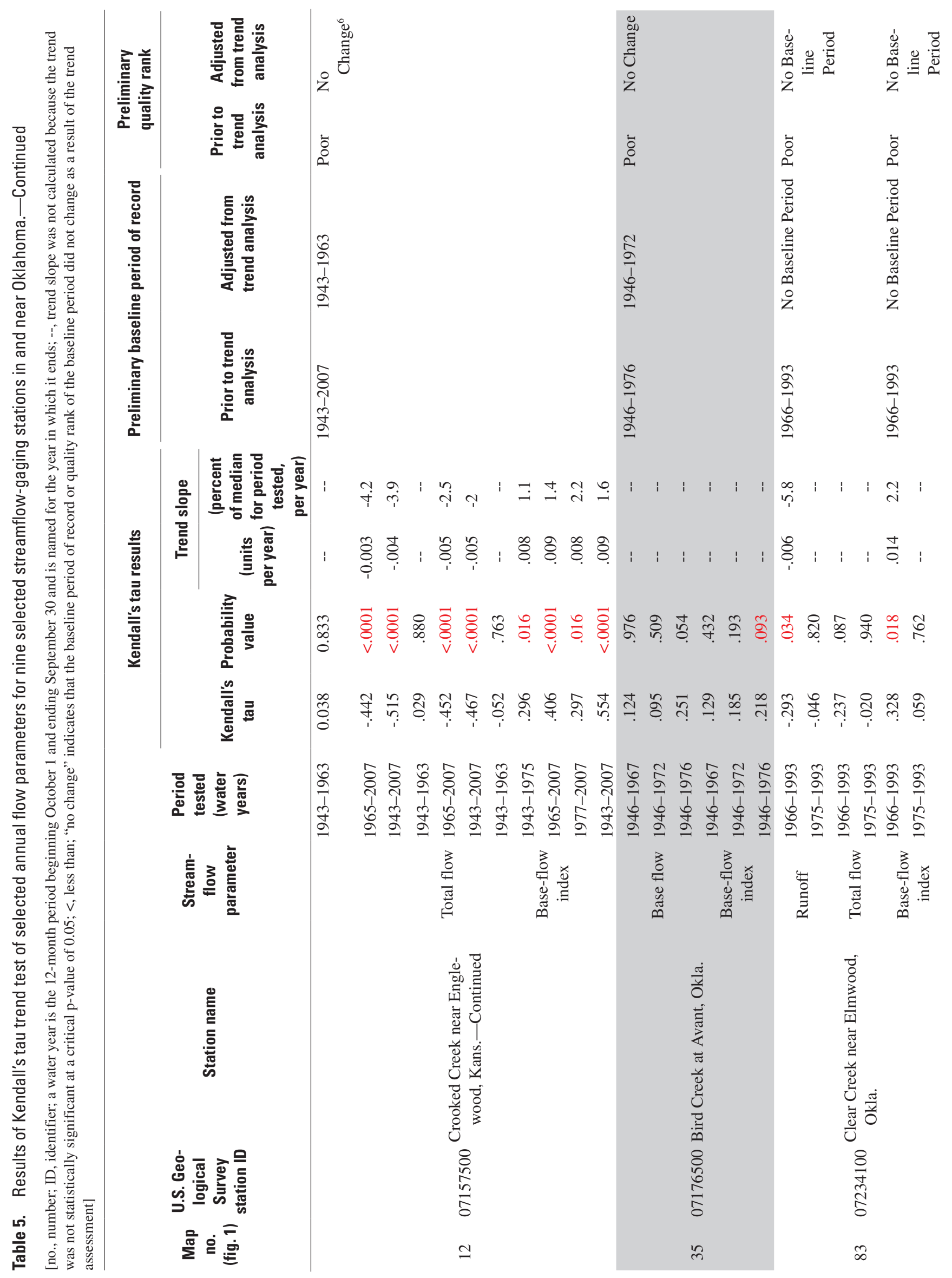




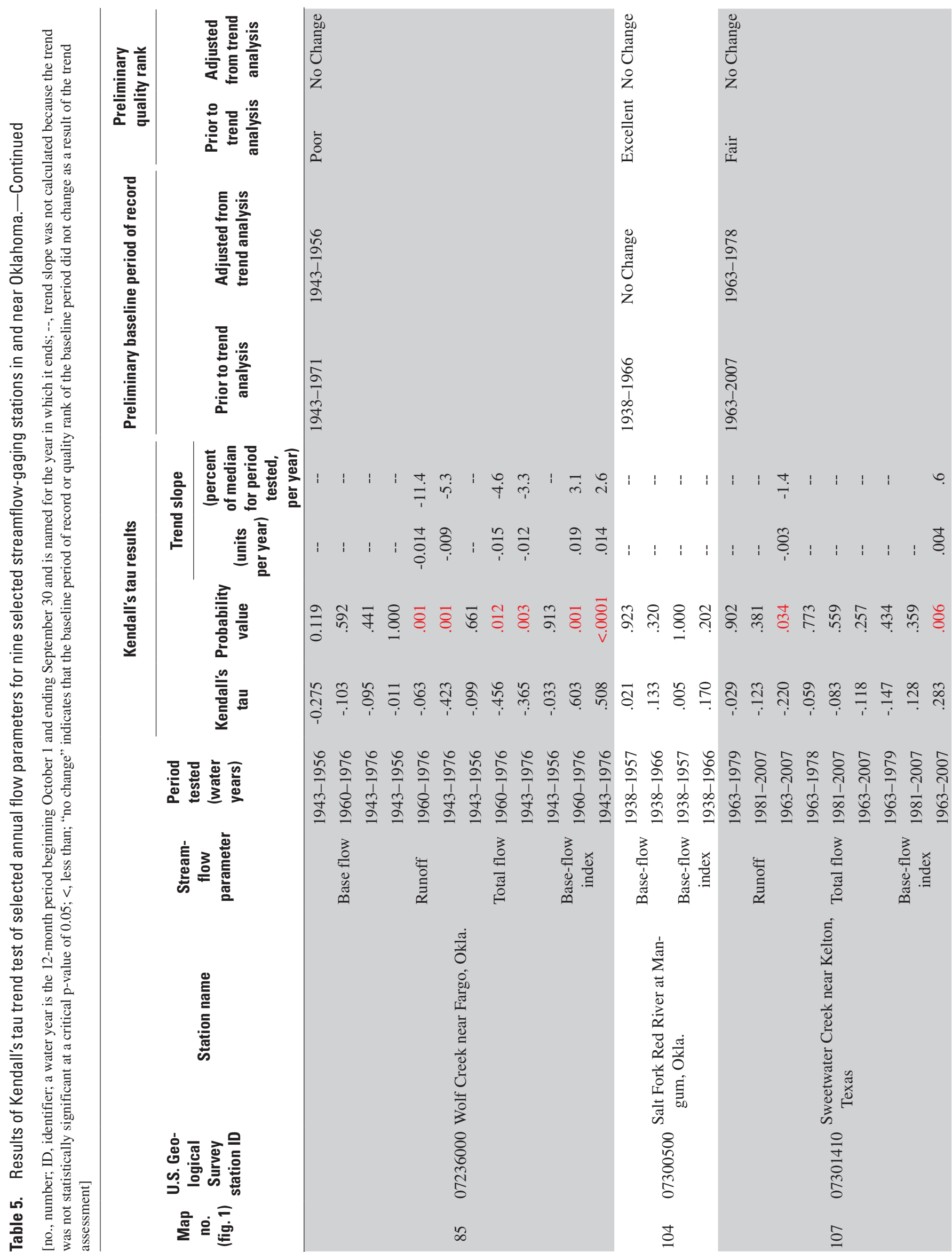




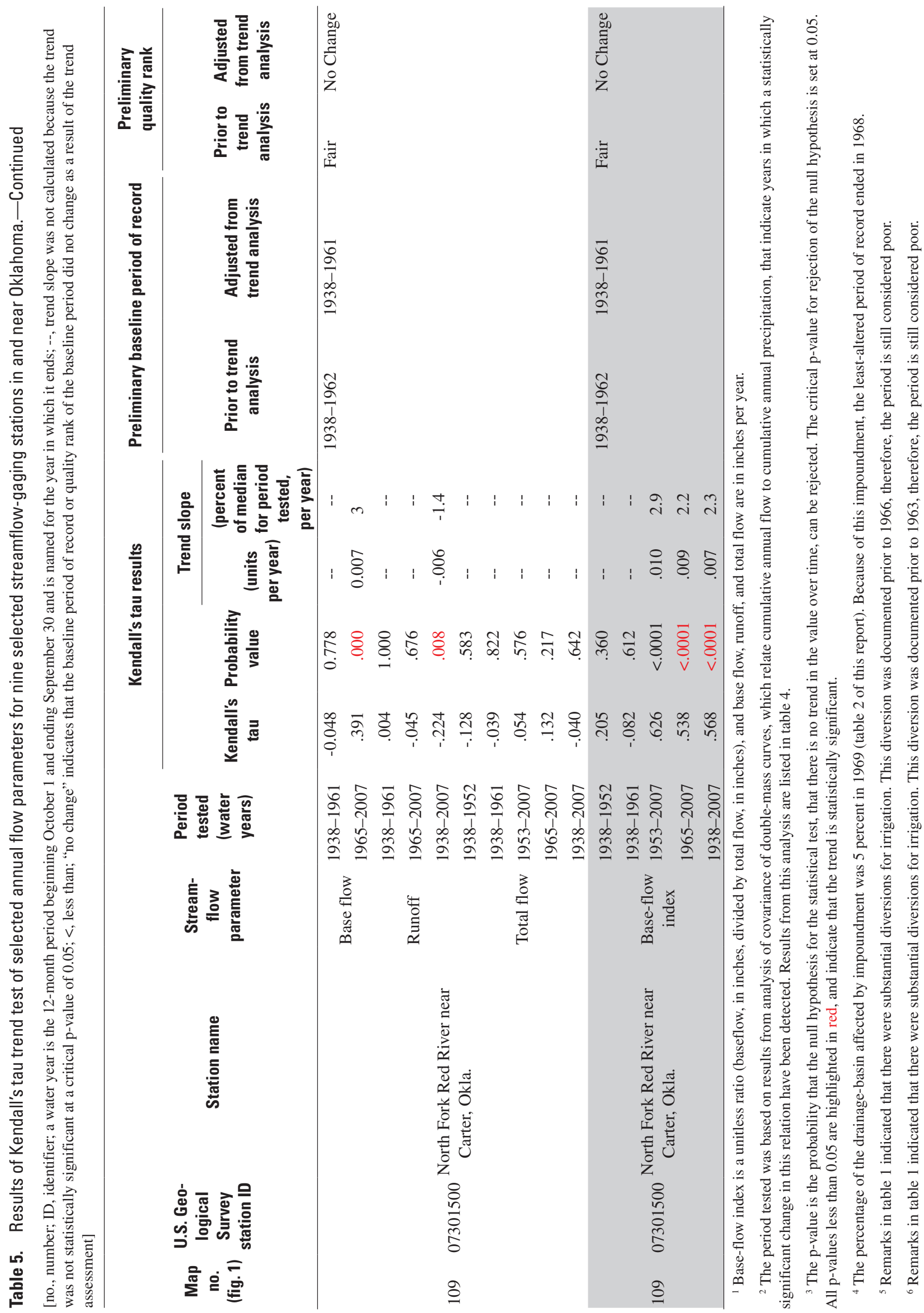


Table 6. Results of the determination of an optimum minimum number of years of streamflow record to consider as a baseline period of record on the basis of testing of variability of annual precipitation between shorter sub-periods and the period 1925-2007 using a Wilcoxon rank-sum test.

[Fraction of rejections, the percentage of sub-periods of the indicated record length where the null hypothesis of no difference in annual precipitation for the sub-period and the period 1925-2007 was rejected (at a probability of less than or equal to 0.05 ) for moving sub-periods starting with 1925; \%, percent; AR, Arkansas; KS, Kansas; MO, Missouri; OK, Oklahoma; TX, Texas; None, no sub-periods were rejected for any moving period of the indicated record length; NA, not applicable]

\begin{tabular}{|c|c|c|c|c|c|c|c|c|c|c|c|c|c|c|}
\hline $\begin{array}{l}\text { Climate division number } \\
\text { and region descriptor } \\
\text { (fig. 3) }\end{array}$ & \multicolumn{7}{|c|}{ Normal period $^{1}$} & \multicolumn{7}{|c|}{ Wet period ${ }^{1}$} \\
\hline AR1 - Northwest & $5 \%$ & None & $4 \%$ & None & None & None & 20 & None & $12 \%$ & $9 \%$ & None & None & NA & 20 \\
\hline AR7 - Southwest & $2 \%$ & None & None & None & None & None & 10 & $5 \%$ & $24 \%$ & $40 \%$ & $10 \%$ & None & NA & 25 \\
\hline KS7 - Southwest & $14 \%$ & $14 \%$ & None & None & None & None & 15 & None & None & None & None & None & NA & 10 \\
\hline KS8 - South Central & $4 \%$ & None & None & None & None & None & 10 & None & $6 \%$ & None & None & None & NA & 15 \\
\hline KS9 - Southeast & $7 \%$ & $4 \%$ & None & None & None & None & 15 & None & None & $9 \%$ & None & None & NA & 20 \\
\hline OK2 - North Central & $5 \%$ & None & None & None & None & None & 10 & $9 \%$ & None & $9 \%$ & None & None & NA & 20 \\
\hline OK3 - Northeast & $10 \%$ & $4 \%$ & None & $4 \%$ & None & None & 25 & $5 \%$ & $18 \%$ & $27 \%$ & None & None & NA & 20 \\
\hline OK4 - West Central & $9 \%$ & $4 \%$ & None & None & None $^{4}$ & None & 15 & $5 \%$ & None & $18 \%$ & $27 \%$ & None & NA & 25 \\
\hline OK5 - Central & $7 \%$ & $2 \%$ & None & None & None & None & 15 & $13 \%$ & $23 \%$ & $45 \%$ & $36 \%$ & None & NA & 25 \\
\hline OK6 - East Central & $12 \%$ & None & $3 \%$ & None & None & None & 20 & $5 \%$ & $47 \%$ & $54 \%$ & $45 \%$ & None & NA & 25 \\
\hline OK7 - Southwest & $5 \%$ & $2 \%$ & $2 \%$ & None & None & None & 20 & $9 \%$ & $29 \%$ & $45 \%$ & $36 \%$ & $15 \%$ & NA & 35 \\
\hline OK8 - South Central & $4 \%$ & None & None & None & None & None & 10 & $14 \%$ & $29 \%$ & $18 \%$ & $9 \%$ & None & NA & 25 \\
\hline OK9 - Southeast & $2 \%$ & None & None & None & None & None & 10 & $9 \%$ & $29 \%$ & $36 \%$ & $9 \%$ & None & NA & 25 \\
\hline
\end{tabular}

${ }^{1}$ The optimum minimum period of record was defined separately for sub-periods starting or mostly in the wet period, and sub-periods starting in the historically typical climate period, which was prior to 1980 . For the 5- and 10-year sub-periods, rejections were tallied separately for sub-periods starting in 1925 through 1980, and sub-periods starting in 1981 through the current year. For the 15- , 20- , and 25-year periods, the cut-off year for defining the wet period started earlier in 1970.

${ }^{2}$ Sub-periods tested include all possible continuous periods of the indicated length. For example, for the test of sub-periods that are 5 years in length, annual precipitation for the periods 1925-1929, 1926-1930, 1927-1931, and so on, were each compared to annual precipitation for the period 1925-2007 by using a Wilcoxon rank-sum test to determine if the null hypothesis should be rejected.

${ }^{3}$ The optimum minimum number of years of record reflects the suggested minimum number of years of continuous streamflow data to use in a baseline period of record for those gages that are located in the respective climate division. The minimum number of years for a baseline period is defined here as the least number of years for which the null hypothesis was not rejected for any tested sub-period of that length.

${ }^{4}$ All rejections occurred for periods starting as late as 1933. All streanflow records started after 1933, so the rejections for this time frame reflect the non-wet period 1934-1978.

${ }^{5}$ A wet-period analysis was not performed separately for the 35 -year periods. 
Table 7. Final baseline period of record for 111 streamflow-gaging stations in and near Oklahoma with at least 10 years of continuous daily streamflow record and a drainage area of less than 2,500 square miles.

[no., number; ID, identifier; a water year is the 12-month period beginning October 1 and ending September 30 and is named for the year in which it ends; Final quality ranking of baseline period indicates the degree of alteration of the streamflow-gaging station and may be lowered if the record length is insufficient to account for climate variability; N, north; SCS, Soil Conservation Service]

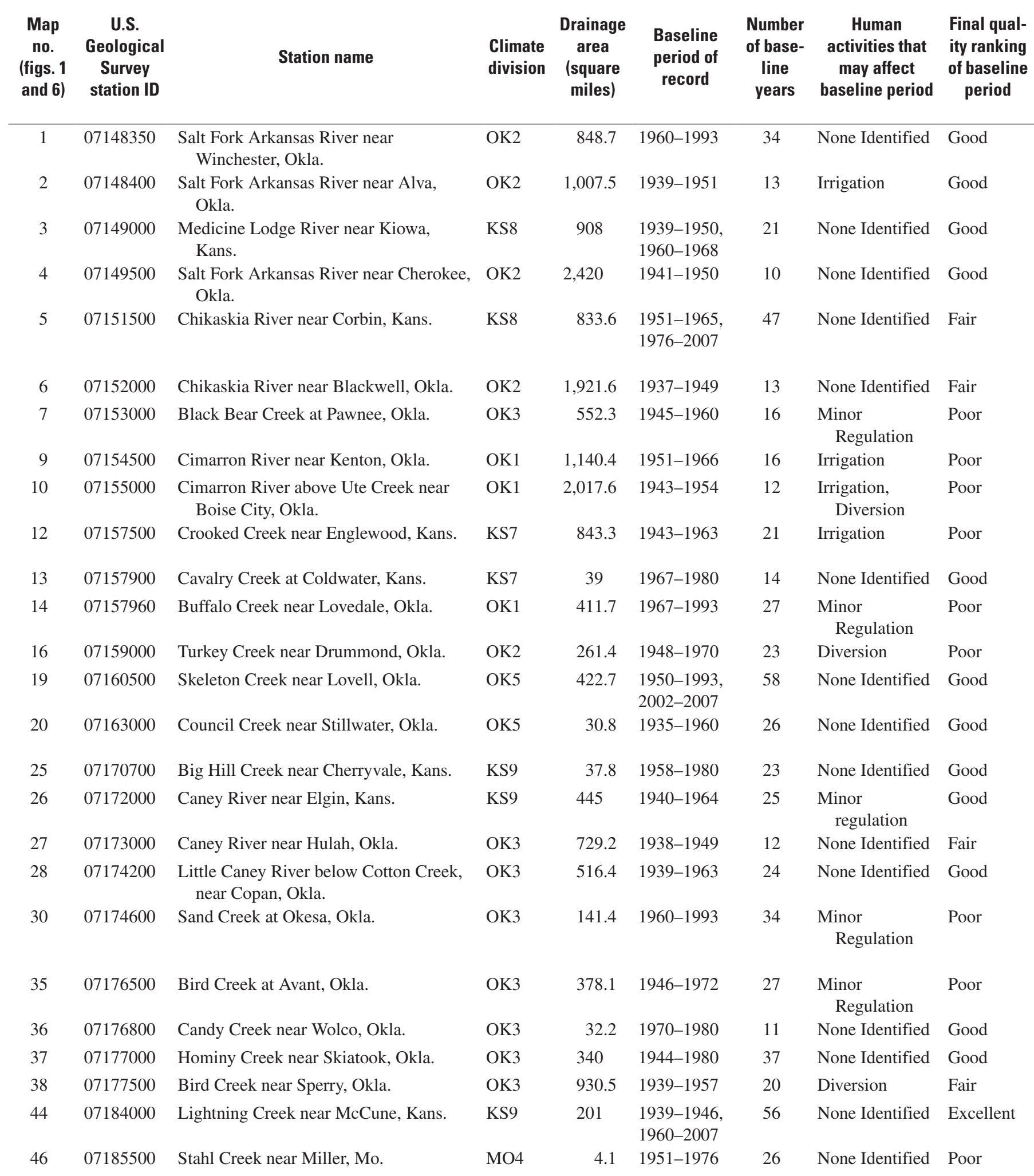


Table 7. Final baseline period of record for 111 streamflow-gaging stations in and near Oklahoma with at least 10 years of continuous daily streamflow record and a drainage area of less than 2,500 square miles.-Continued

[no., number; ID, identifier; a water year is the 12-month period beginning October 1 and ending September 30 and is named for the year in which it ends; Final quality ranking of baseline period indicates the degree of alteration of the streamflow-gaging station and may be lowered if the record length is insufficient to account for climate variability; N, north; SCS, Soil Conservation Service]

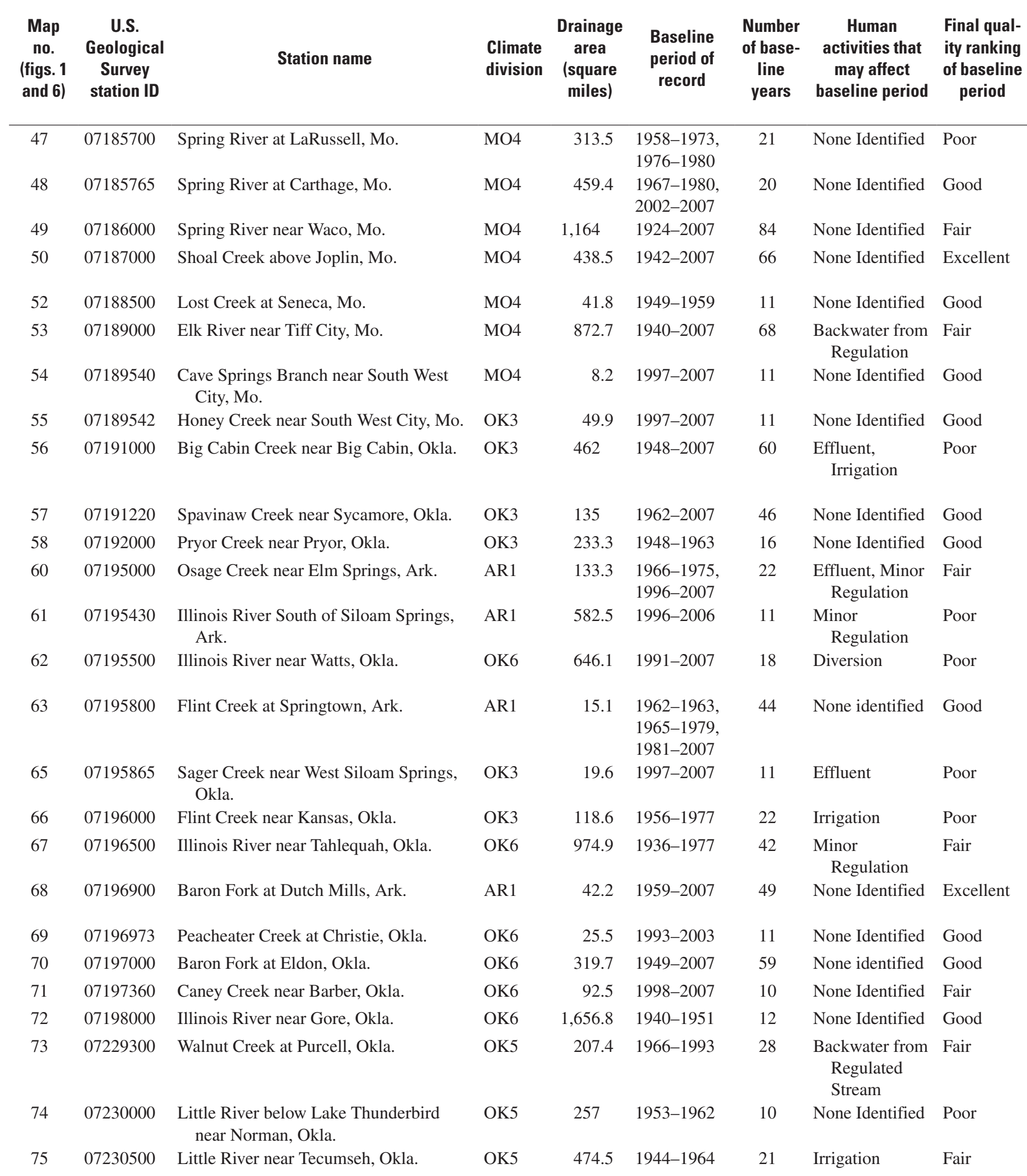


Table 7. Final baseline period of record for 111 streamflow-gaging stations in and near Oklahoma with at least 10 years of continuous daily streamflow record and a drainage area of less than 2,500 square miles.-Continued

[no., number; ID, identifier; a water year is the 12-month period beginning October 1 and ending September 30 and is named for the year in which it ends; Final quality ranking of baseline period indicates the degree of alteration of the streamflow-gaging station and may be lowered if the record length is insufficient to account for climate variability; N, north; SCS, Soil Conservation Service]

\begin{tabular}{|c|c|c|c|c|c|c|c|c|}
\hline $\begin{array}{l}\text { Map } \\
\text { no. } \\
\text { (figs. } 1 \\
\text { and 6) }\end{array}$ & $\begin{array}{c}\text { U.S. } \\
\text { Geological } \\
\text { Survey } \\
\text { station ID }\end{array}$ & Station name & $\begin{array}{l}\text { Climate } \\
\text { division }\end{array}$ & $\begin{array}{l}\text { Drainage } \\
\text { area } \\
\text { (square } \\
\text { miles) }\end{array}$ & $\begin{array}{l}\text { Baseline } \\
\text { period of } \\
\text { record }\end{array}$ & $\begin{array}{c}\text { Number } \\
\text { of base- } \\
\text { line } \\
\text { years }\end{array}$ & $\begin{array}{c}\text { Human } \\
\text { activities that } \\
\text { may affect } \\
\text { baseline period }\end{array}$ & $\begin{array}{l}\text { Final qual- } \\
\text { ity ranking } \\
\text { of baseline } \\
\text { period }\end{array}$ \\
\hline 76 & 07231000 & Little River near Sasakwa, Okla. & OK5 & 911.4 & $1943-1961$ & 19 & None Identified & Good \\
\hline 77 & 07232000 & Gaines Creek near Krebs, Okla. & OK6 & 600.3 & $1943-1963$ & 21 & None Identified & Excellent \\
\hline 80 & 07233000 & Coldwater Creek near Hardesty, Okla. & OK1 & $1,055.5$ & 1940-1964 & 25 & None Identified & Excellent \\
\hline 81 & 07233500 & Palo Duro Creek near Spearman, Texas & TX1 & 640.9 & 1946-1969 & 24 & Diversion & Good \\
\hline 85 & 07236000 & Wolf Creek near Fargo, Okla. & OK1 & $1,511.1$ & $1943-1956$ & 16 & Impoundment & Poor \\
\hline 91 & 07244000 & Deep Fork near Dewar, Okla. & OK6 & $2,355.5$ & $1938-1950$ & 13 & $\begin{array}{l}\text { Minor } \\
\text { Regulation }\end{array}$ & Fair \\
\hline 92 & 07245500 & Sallisaw Creek near Sallisaw, Okla. & OK6 & 185.8 & $1943-1962$ & 20 & Diversion & Poor \\
\hline 93 & 07247000 & Poteau River at Cauthron, Ark. & AR4 & 208.8 & $1940-1963$ & 29 & $\begin{array}{l}\text { Minor } \\
\text { Regulation }\end{array}$ & Good \\
\hline 95 & 07247250 & $\begin{array}{l}\text { Black Fork below Big Creek near Page, } \\
\text { Okla. }\end{array}$ & OK9 & 96.8 & 1992-2007 & 16 & None Identified & Good \\
\hline 96 & 07247500 & Fourche Maline near Red Oak, Okla. & OK9 & 123.5 & $1939-1963$ & 25 & Impoundment & Fair \\
\hline 97 & 07248500 & Poteau River near Wister, Okla. & OK9 & $1,019.4$ & $1939-1948$ & 10 & None identified & Good \\
\hline 103 & 07300000 & $\begin{array}{l}\text { Salt Fork Red River near Wellington, } \\
\text { Texas }\end{array}$ & TX2 & $1,029.4$ & $1953-1966$ & 14 & Irrigation & Fair \\
\hline 104 & 07300500 & Salt Fork Red River at Mangum, Okla. & OK7 & $1,380.4$ & 1938-1966 & 29 & None identified & Excellent \\
\hline 107 & 07301410 & Sweetwater Creek near Kelton, Texas & TX2 & 305 & $1963-1978$ & 15 & Diversion & Fair \\
\hline 109 & 07301500 & North Fork Red River near Carter, Okla. & OK4 & 2,155 & $1938-1961$ & 25 & None Identified & Fair \\
\hline 111 & 07303400 & $\begin{array}{l}\text { Elm Fork of N Fork Red River near Carl, } \\
\text { Okla. }\end{array}$ & OK7 & 449.3 & $\begin{array}{l}1960-1979 \\
1995-2007\end{array}$ & 33 & $\begin{array}{l}\text { Diversion/ } \\
\text { Withdrawal }\end{array}$ & Poor \\
\hline 112 & 07303500 & $\begin{array}{l}\text { Elm Fork of N Fork Red River near } \\
\text { Mangum, Okla. }\end{array}$ & OK7 & 868.3 & 1938-1976 & 39 & $\begin{array}{l}\text { Minor } \\
\text { Regulation }\end{array}$ & Fair \\
\hline 113 & 07304500 & Elk Creek near Hobart, Okla. & OK7 & 563.5 & 1950-1966 & 17 & Irrigation & Poor \\
\hline 118 & 07311500 & Deep Red Creek near Randlett, Okla. & OK7 & 619.7 & $\begin{array}{l}1950-1963 \\
1970-1973\end{array}$ & 18 & None identified & Good \\
\hline 119 & 07313000 & Little Beaver Creek near Duncan, Okla. & OK8 & 160.6 & 1949-1963 & 15 & None Identified & Good \\
\hline
\end{tabular}


Table 7. Final baseline period of record for 111 streamflow-gaging stations in and near Oklahoma with at least 10 years of continuous daily streamflow record and a drainage area of less than 2,500 square miles.-Continued

[no., number; ID, identifier; a water year is the 12-month period beginning October 1 and ending September 30 and is named for the year in which it ends; Final quality ranking of baseline period indicates the degree of alteration of the streamflow-gaging station and may be lowered if the record length is insufficient to account for climate variability; N, north; SCS, Soil Conservation Service]

\begin{tabular}{|c|c|c|c|c|c|c|c|c|}
\hline $\begin{array}{l}\text { Map } \\
\text { no. } \\
\text { (figs. } 1 \\
\text { and 6) }\end{array}$ & $\begin{array}{c}\text { U.S. } \\
\text { Geological } \\
\text { Survey } \\
\text { station ID }\end{array}$ & Station name & $\begin{array}{l}\text { Climate } \\
\text { division }\end{array}$ & $\begin{array}{l}\text { Drainage } \\
\text { area } \\
\text { (square } \\
\text { miles) }\end{array}$ & $\begin{array}{c}\text { Baseline } \\
\text { period of } \\
\text { record }\end{array}$ & $\begin{array}{c}\text { Number } \\
\text { of base- } \\
\text { line } \\
\text { years }\end{array}$ & $\begin{array}{c}\text { Human } \\
\text { activities that } \\
\text { may affect } \\
\text { baseline period }\end{array}$ & $\begin{array}{c}\text { Final qual- } \\
\text { ity ranking } \\
\text { of baseline } \\
\text { period }\end{array}$ \\
\hline 120 & 07313500 & Beaver Creek near Waurika, Okla. & OK8 & 579 & 1954-1976 & 23 & None Identified & Good \\
\hline 122 & 07316500 & Washita River near Cheyenne, Okla. & OK4 & 782.3 & $1938-1957$ & 18 & Irrigation & Poor \\
\hline 128 & 07325000 & Washita River near Clinton, Okla. & OK4 & $1,998.8$ & $1936-1955$ & 20 & $\begin{array}{l}\text { Irrigation, } \\
\text { Minor } \\
\text { Regulation }\end{array}$ & Fair \\
\hline 130 & 07326000 & Cobb Creek near Fort Cobb, Okla. & OK7 & 318.8 & $1940-1950$ & 11 & $\begin{array}{l}\text { Minor } \\
\text { Regulation }\end{array}$ & Good \\
\hline 136 & 07327490 & $\begin{array}{l}\text { Little Washita River near Ninnekah, } \\
\text { Okla. }\end{array}$ & OK5 & 213.3 & $1952-1969$ & 18 & $\begin{array}{l}\text { Irrigation, } \\
\text { Minor } \\
\text { Regulation }\end{array}$ & Poor \\
\hline 140 & 07329000 & Rush Creek at Purdy, Okla. & OK8 & 143.3 & $1940-1953$ & 26 & None Identified & Good \\
\hline 145 & 07330500 & Caddo Creek near Ardmore, Okla. & OK8 & 304 & $1937-1950$ & 14 & None Identified & Excellent \\
\hline 146 & 07332400 & Blue River at Milburn, Okla. & OK8 & 208.5 & $1966-1986$ & 21 & None Identified & Excellent \\
\hline 147 & 07332500 & Blue River near Blue, Okla. & OK8 & 489.8 & $1937-1980$ & 44 & $\begin{array}{l}\text { Minor } \\
\text { Regulation }\end{array}$ & Fair \\
\hline 148 & 07332600 & Bois D’Arc Creek near Randolph, Texas & TX3 & 74 & 1964-1985 & 22 & None Identified & Excellent \\
\hline 157 & 07336000 & Tenmile Creek near Miller, Okla. & OK9 & 70.1 & $1956-1970$ & 15 & None Identified & Excellent \\
\hline 158 & 07336200 & Kiamichi River near Antlers, Okla. & OK9 & $1,158.3$ & $1973-1982$ & 10 & Diversion & Fair \\
\hline 159 & 07336500 & Kiamichi River near Belzoni, Okla. & OK9 & $1,452.6$ & $1926-1972$ & 47 & Diversion & Fair \\
\hline 160 & 07336750 & Little Pine Creek near Kanawha, Texas & TX4 & 77.2 & $1970-1980$ & 11 & None Identified & Good \\
\hline 161 & 07336800 & Pecan Bayou near Clarksville, Texas & TX4 & 101.5 & $1963-1977$ & 15 & None Identified & Good \\
\hline 162 & 07337500 & Little River near Wright City, Okla. & OK9 & 665 & $1945-1966$ & 22 & None identified & Excellent \\
\hline 163 & 07337900 & Glover River near Glover, Okla. & OK9 & 328.6 & $1962-2007$ & 46 & None Identified & Excellent \\
\hline 164 & 07338500 & $\begin{array}{l}\text { Little River below Lukfata Creek, near } \\
\text { Idabel, Okla. }\end{array}$ & OK9 & 1,260 & $1930-1968$ & 39 & $\begin{array}{l}\text { Diversion/ } \\
\text { Withdrawal }\end{array}$ & Fair \\
\hline 165 & 07338750 & Mountain Fork at Smithville, Okla. & OK9 & 330.7 & 1992-2007 & 16 & None Identified & Poor \\
\hline 166 & 07339000 & Mountain Fork near Eagletown, Okla. & OK9 & 820.5 & $1930-1968$ & 39 & None Identified & Good \\
\hline 167 & 07339500 & Rolling Fork near DeQueen, Ark. & AR7 & 188.1 & 1949-1976 & 28 & None Identified & Excellent \\
\hline 168 & 07340300 & Cossatot River near Vandervoort, Ark. & AR4 & 91.4 & 1967-2007 & 29 & None identified & Excellent \\
\hline
\end{tabular}


Table 7. Final baseline period of record for 111 streamflow-gaging stations in and near Oklahoma with at least 10 years of continuous daily streamflow record and a drainage area of less than 2,500 square miles.-Continued

[no., number; ID, identifier; a water year is the 12-month period beginning October 1 and ending September 30 and is named for the year in which it ends; Final quality ranking of baseline period indicates the degree of alteration of the streamflow-gaging station and may be lowered if the record length is insufficient to account for climate variability; N, north; SCS, Soil Conservation Service]

\begin{tabular}{|c|c|c|c|c|c|c|c|c|}
\hline $\begin{array}{c}\text { Map } \\
\text { no. } \\
\text { (figs. } 1 \\
\text { and 6) }\end{array}$ & $\begin{array}{c}\text { U.S. } \\
\text { Geological } \\
\text { Survey } \\
\text { station ID }\end{array}$ & Station name & $\begin{array}{l}\text { Climate } \\
\text { division }\end{array}$ & $\begin{array}{l}\text { Drainage } \\
\text { area } \\
\text { (square } \\
\text { miles) }\end{array}$ & $\begin{array}{c}\text { Baseline } \\
\text { period of } \\
\text { record }\end{array}$ & $\begin{array}{c}\text { Number } \\
\text { of base- } \\
\text { line } \\
\text { years }\end{array}$ & $\begin{array}{c}\text { Human } \\
\text { activities that } \\
\text { may affect } \\
\text { baseline period }\end{array}$ & $\begin{array}{c}\text { Final qual- } \\
\text { ity ranking } \\
\text { of baseline } \\
\text { period }\end{array}$ \\
\hline 169 & 07340500 & Cossatot River near DeQueen, Ark. & AR7 & 370.6 & 1939-1974 & 36 & None Identified & Good \\
\hline 171 & 07341200 & Saline River near Lockesburg, Ark. & AR7 & 259.3 & 1964-1974 & 11 & None Identified & Excellent \\
\hline
\end{tabular}

